RECEIVED

DEC 281998

OSTI

\title{
Evaluation of Gas Reburning and Low N0x Burners on a Wall Fired Boiler
}

\author{
Final Report \\ September 1998
}

Work Performed Under Contract No.: DE-FC22-91PC79796

For

U.S. Department of Energy

Office of Fossil Energy

Federal Energy Technology Center

P.O. Box 880

Morgantown, West Virginia 26507-0880

By

Energy \& Environmental Research Corporation

18 Mason

Irvine, California 92618 


\section{Disclaimer}

This report was prepared as an account of work sponsored by an agency of the United States Government. Neither the United States Government nor any agency thereof, nor any of their employees, makes any warranty, express or implied, or assumes any legal liability or responsibility for the accuracy, completeness, or usefulness of any information, apparatus, product, or process disclosed, or represents that its use would not infringe privately owed rights. Reference herein to any specific commercial product, process, or service by trade name, trademark, manufacturer, or otherwise does not necessarily constitute or imply its endorsement; recommendation, or favoring by the United States Government or any agency thereof. The views and opinions of authors expressed herein do not necessarily state or reflect those of the United States Government or any agency thereof. 


\section{DISCLAIMER}

Portions of this document may be illegible in electronic image products. Images are produced from the best available original document. 


\section{DISCLAIMERS}

\section{U.S. Department of Energy}

This report was prepared by Energy and Environmental Research Corporation pursuant to a cooperative agreement funded partially by the U. S. Department of Energy, and neither Energy and Environmental Research Corporation nor any of its subcontractors nor the U. S. Department of Energy, nor any person acting on behalf of either:

(a) Makes any warranty or representation, express or implied, with respect to the accuracy, completeness, or usefulness of the information contained in this report, or that the use of any information, apparatus, method, or process disclosed in this report may not infringe privately owned rights; or

(b) Assumes any liabilities with respect to the use of, or for damages resulting from the use of, any information, apparatus, method or process disclosed in this report.

Reference herein to any specific product, process, or service by trade name, trademark, manufacturer, or otherwise, does not necessarily constitute or imply its endorsement, recommendation, or favoring by the U. S. Department of Energy. The views and opinions of authors herein do not necessarily state or reflect those of the U.S. Department of Energy.

\section{Gas Research Institute}

LEGAL NOTICE: This report was prepared by Energy and Environmental Research Corporation (EER) as an account of work sponsored by the Gas Research Institute (GRI). Neither GRI, members of GRI, nor any person acting on behalf of either:

a. Makes any warranty or representation, either express or implied, with respect to the accuracy, completeness, or usefulness of the information contained in this report, or that the use of any information, apparatus, method, or process disclosed in this report may not infringe on privately-owned rights; or

b. Assumes any liability with respect to the use of, or for damages resulting from the use of, any information, apparatus, method, or process disclosed in this report. 


\section{ABSTRACT}

Under the U.S. Department of Energy's Clean Coal Technology Program (Round 3), a project was completed to demonstrate control of boiler emissions that comprise acid rain precursors, especially $\mathrm{NO}_{\mathrm{x}}$. The project involved operating gas reburning technology combined with low $\mathrm{NO}_{x}$ burner technology (GR-LNB) on a coal-fired utility boiler. Low $\mathrm{NO}_{x}$ burners are designed to create less $\mathrm{NO}_{x}$ than conventional burners. However, the $\mathrm{NO}_{\mathrm{x}}$ control achieved is in the range of $30-60 \%$, and typically $50 \%$. At the higher $\mathrm{NO}_{\mathrm{x}}$ reduction levels, $\mathrm{CO}$ emissions tend to be higher than acceptable standards. Gas Reburning (GR) is designed to reduce the level of $\mathrm{NO}_{\mathrm{x}}$ in the flue gas by staged fuel combustion. When combined, GR and LNBs work in harmony to both minimize $\mathrm{NO}_{x}$ emissions and maintain an acceptable level of $\mathrm{CO}$ emissions.

The demonstration was performed at Public Service Company of Colorado's (PSCo) Cherokee Unit 3, located in Denver, Colorado. This unit is a $172 \mathrm{MW}_{\mathrm{e}}$ wall-fired boiler that uses Colorado bituminous, low-sulfur coal and had a pre GR-LNB baseline $\mathrm{NO}_{x}$ emission of $0.73 \mathrm{lb} / 10^{6} \mathrm{Btu}$. The target for the project was a reduction of 70 percent in $\mathrm{NO}_{\mathrm{x}}$ emissions. Project sponsors included the U.S. Department of Energy, the Gas Research Institute, Public Service Company of Colorado, Colorado Interstate Gas, Electric Power Research Institute, and the Energy and Environmental Research Corporation (EER).

EER conducted a comprehensive test demonstration program over a wide range of boiler conditions. Over 4,000 hours of operation were achieved. Intensive measurements were taken to quantify the reductions in $\mathrm{NO}_{x}$ emissions, the impact on boiler equipment and operability, and all factors influencing costs. The results showed that GR-LNB technology achieved excellent emission reductions. Although the performance of the low $\mathrm{NO}_{\mathrm{x}}$ burners (supplied by others) was somewhat less than expected, a $\mathrm{NO}_{x}$ reduction of $65 \%$ was achieved at an average gas heat input of $18 \%$. The performance goal of $70 \%$ reduction was met on many test runs, but at higher gas heat inputs. The impact on boiler equipment was determined to be very minimal. 
Toward the end of the testing, the flue gas recirculation (used to enhance gas penetration into the furnace) system was removed and new high pressure gas injectors were installed. Further, the low $\mathrm{NO}_{\mathrm{x}}$ burners were modified and gave better $\mathrm{NO}_{\mathrm{x}}$ reduction performance. These modifications resulted in a similar $\mathrm{NO}_{x}$ reduction performance $(64 \%)$ at a reduced level of gas heat input $(\sim 13 \%)$. In addition, the OFA injectors were re-designed to provide for better control of $\mathrm{CO}$ emissions. Although not a part of this project, the use of natural gas as the primary fuel with gas reburning was also tested. The gas/gas reburning tests demonstrated a reduction in $\mathrm{NO}_{\mathrm{x}}$ emissions of $43 \%\left(0.30 \mathrm{lb} / 10^{6}\right.$ Btu reduced to $0.17 \mathrm{lb} / 10^{6}$ Btu) using $7 \%$ gas heat input.

Economics are a key issue affecting technology development. Application of GR-LNB requires modifications to existing power plant equipment and as a result, the capital and operating costs depend largely on site-specific factors such as: gas availability at the site, gas to coal delivered price differential, sulfur dioxide removal requirements, windbox pressure, existing burner throat diameters, and reburn zone residence time available. Based on the results of this CCT project, EER expects that most GR-LNB installations will achieve at least $60 \% \mathrm{NO}_{\mathrm{x}}$ control when firing $10-15 \%$ gas. The capital cost estimate for installing a GR-LNB system on a $300 \mathrm{MW}_{\mathrm{e}}$ unit is approximately $\$ 25 / \mathrm{kW}_{\mathrm{e}}$ plus the cost of a gas pipeline (if required). Operating costs are almost entirely related to the differential cost of the natural gas compared to coal.

Title IV, Phase 2 of the Clean Air Act Amendments of 1990 specify a $\mathrm{NO}_{x}$ emissions limit of $0.46 \mathrm{lb} / 10^{6} \mathrm{Btu}$ (regulation for the year 2000 ) for wall-fired boilers. For the Cherokee Unit \#3 application, low $\mathrm{NO}_{x}$ burners alone will produce a $\mathrm{NO}_{x}$ emission level of $0.46 \mathrm{lb} / 10^{6} \mathrm{Btu}$. Although sufficient to meet the regulatory limit, the $\mathrm{CO}$ control was not achieved unless low levels of GR were used. Also, any future more stringent limits will not be met with burners alone; additional control will be required. For this unit it was demonstrated that GR could be cost competitive with other $\mathrm{NO}_{x}$ reduction techniques due to its low capital and operating cost (with small levels of heat input from natural gas). Based on the success of the project, the host utility elected to retain the GR-LNB equipment for future use. 


\section{ACKNOWLEDGMENTS}

Energy and Environmental Research Corporation (EER) wishes to express appreciation to the project sponsors and their project managers for assistance received in conducting this project:

U. S. Department of Energy - Mr. Jerry Hebb

Gas Research Institute - Mr. Paul Bautista

Electric Power Research Institute - Mr. George Offen

Colorado Interstate Gas Company - Mr. John Grossman

Public Service Company of Colorado - Mr. Charles Bomberger

The assistance and cooperation of the operations and maintenance personnel of the Public Service Company of Colorado's Cherokee Station was also greatly appreciated. 


\section{POINTS OF CONTACT}

For more information regarding Gas Reburning or Gas Reburning integrated with Low $\mathrm{NO}_{x}$ Burners, please contact:

Dr. Blair A. Folsom, Senior Vice President

Energy and Environmental Research Corporation

18 Mason

Irvine, California 92718

Phone (949) 859-8851

FAX (949) 859-3194

or

Mr. Todd M. Sommer, Vice President

Energy and Environmental Research Corporation

1345 N. Main St.

Orrville, Ohio 44667

Phone (330) 682-4007

FAX (330) 684-2110

\section{AUTHORS}

The following EER personnel contributed in the preparation of this report:

Robert Ashworth

Rafik Beshai

Donald Engelhardt

Blair Folsom

David Moyeda

Roy Payne

Todd Sommer 
EXECUTIVE SUMMARY

1.0 OVERVIEWpose of the Report $\ldots \ldots \ldots \ldots \ldots \ldots \ldots \ldots \ldots \ldots \ldots$ 1-1

1.2 Basis of the Report $\ldots \ldots \ldots \ldots \ldots \ldots \ldots \ldots \ldots \ldots \ldots$ 1-1

1.3 Reference Material . . . . . . . . . . . . . . . . 1-2

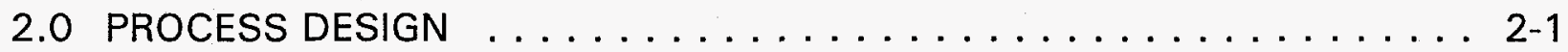

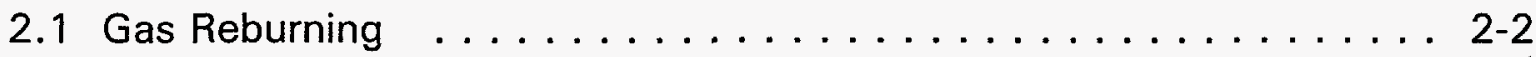

2.1 .1 Modes of Operation ................. 2-2

2.1.2 GR Process Design Guidelines . . . . . . . . . 2-6

2.1.3 GR Process Design Tools ............... 2-13

2.1.4 GR Comparison of Theory with Practice ........ 2-16

2.2 Low $\mathrm{NO}_{x}$ Burners $\ldots \ldots \ldots \ldots \ldots \ldots \ldots \ldots \ldots \ldots \ldots \ldots . \ldots \ldots$

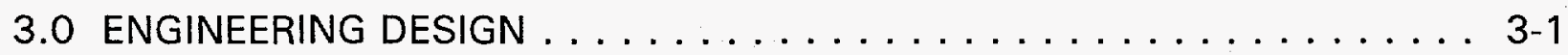

3.1 Gas Reburning System $\ldots \ldots \ldots \ldots \ldots \ldots \ldots \ldots$ 3-1

3.1.1 Natural Gas System ... . . . . . . . . . 3-1

3.1.2 Flue Gas Recirculation System . . . . . . . . . 3-3

3.1.3 Overfire Air (OFA) System . . . . . . . . . . 3-3

3.2 Low NOx Burners $\ldots \ldots \ldots \ldots \ldots \ldots \ldots \ldots \ldots \ldots . . \ldots \ldots$

3.3 Furnace/Boiler . . . . . . . . . . . . . . . . . . . . . . . . . . 3-8

3.3.1 Bent Tube Openings . . . . . . . . . . 3-8

3.3.2 Combustion Air (Overfire Air Source) . . . . . . . 3-8

3.3.3 FGR Source . . . . . . . . . . . . . 3-9

3.3.4 Equipment Footprint $\ldots \ldots \ldots \ldots \ldots \ldots \ldots . . \ldots \ldots$

3.4 Balance of Plant . . . . . . . . . . . . . . . . 3-10

3.4.1 Electrical Power Distribution ........... 3-10

3.4.2 Plant and Instrument Air . . . . . . . . . 3-10

3.4.3 Controls ................... 3-11 
Section

4.0 SYSTEM OPERATION $\ldots \ldots \ldots \ldots \ldots \ldots \ldots \ldots \ldots \ldots . \ldots \ldots$ 4-1

4.1 Control System . . . . . . . . . . . . . . . 4-1

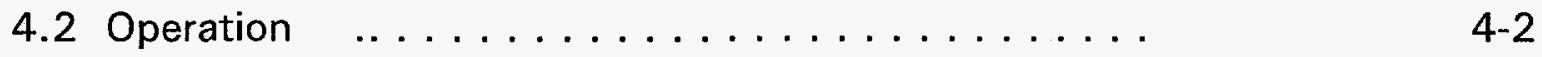

$4.2 .2 \quad$ LNB System $\ldots \ldots \ldots \ldots \ldots \ldots \ldots \ldots \ldots \ldots$

4.3 Optimization . . . . . . . . . . . . . . .

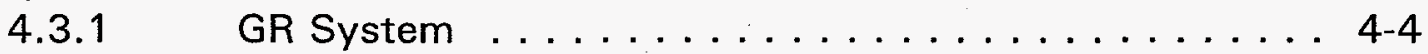

4.3.2 LNB System . . . . . . . . . . . .

5.0 TECHNOLOGY PERFORMANCE $\ldots \ldots \ldots \ldots \ldots \ldots \ldots \ldots \ldots$ 5-1

5.1 Baseline Tesțing . . . . . . . . . . . . . . . . 5-1

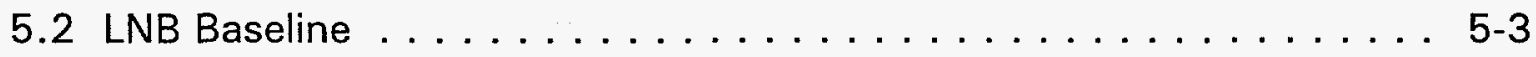

5.3 GR-LNB (First Generation GR) $\ldots \ldots \ldots \ldots \ldots \ldots \ldots \ldots$ 5-6

5.3.1 Gas Heat Input Variation . . . . . . . . . . . 5-8

5.3 .2 Overfire Air (OFA) Variation .............. 5-9

5.3.3 Flue Gas Recirculation (FGR) Variation . . . . . . . . . 5-9

5.3 .4 Assessment of Results . . . . . . . . . . . 5-11

5.3.5 Reduced Load Testing . . . . . . . . . . 5 5-15

5.4 GR-LNB (Second Generation GR) . . . . . . . . . . . . 5-19

5.4 .1 LNB Modifications . . . . . . . . . . . . . 5-20

5.4 .2 Modified GR-LNB System . . . . . . . . . . 5-22

5.4 .3 Assessment of Results . . . . . . . . . . . 5 5-22

$5.5 \mathrm{Gas} /$ Gas Reburning Testing $\ldots \ldots \ldots \ldots \ldots \ldots \ldots \ldots \ldots$ 5-26

6.0 BOILER IMPACTS $\ldots \ldots \ldots \ldots \ldots \ldots \ldots \ldots \ldots \ldots \ldots \ldots .6 \ldots \ldots \ldots$

6.1 Thermal Performance $\ldots \ldots \ldots \ldots \ldots \ldots \ldots \ldots . \ldots . \ldots 6$ 6-1

6.2 Furnace Conditions $\ldots \ldots \ldots \ldots \ldots \ldots \ldots \ldots \ldots \ldots \ldots$

6.3 Tubewear $\ldots \ldots \ldots \ldots \ldots \ldots \ldots \ldots \ldots \ldots \ldots \ldots .6 \ldots \ldots \ldots$ 
6.4 Additional Observations $\ldots \ldots \ldots \ldots \ldots \ldots \ldots \ldots \ldots .6 \ldots$

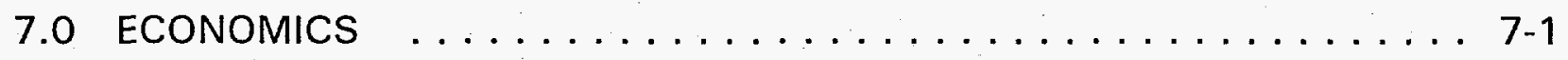

7.1 GR-LNB Economic Paramete $+33 X \ldots \ldots \ldots \ldots \ldots \ldots$ 7-2

7.3 GR-LNB Operating Cost $\ldots \ldots \ldots \ldots \ldots \ldots \ldots \ldots \ldots$

7.4 Summary of Performance and Economics $\ldots \ldots \ldots \ldots \ldots$. . . . . .

7.5 Effect of Variables on Economics . . . . . . . . . 7-11

7.6 GR-LNB Comparison with other $\mathrm{NO}_{\mathrm{x}}$ Control Technologies . . . . . 7-16

\section{REFERENCES}

BIBLIOGRAPHY

\section{LIST OF TABLES}

2-1 GR Design Guidelines . . . . . . . . . . . . . . . . 2-8

6-1 Thermal Performance Summary (Full Load - $150 \mathrm{MW}_{\mathrm{e}}$ ) . . . . . . . . 6-2

6-2 Thermal Performance Summary (Mid Load - $120 \mathrm{MW}_{\mathrm{e}}$ ) . . . . . . . . . 6-3

6-3 Thermal Performance Summary (Low Load - $90 \mathrm{MW}_{\mathrm{e}}$ ) . . . . . . . . . 6 6-4

$7-1$ Cost Factors . . . . . . . . . . . . . . . . . . 7-3

7-2 Major Equipment List . . . . . . . . . . . . . . . . 7-4

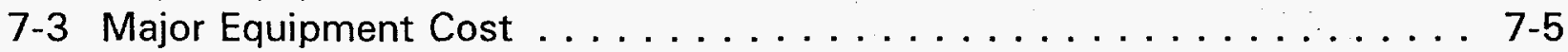

$7-4$ GR-LNB Capital Cost . . . . . . . . . . . . . . 7-6

$7-5$ GR-LNB Operating Cost . . . . . . . . . . . . . . .

7-6 GR Retrofit Cost and Performance Summary . . . . . . . . . . . 7-10

7-7 Reburning Fuel Comparison . . . . . . . . . . . . 7-17

7-8 300 MWe Wall-fired $\mathrm{NO}_{x}$ Control Comparison . . . . . . . . . 7-16 


\section{LIST OF FIGURES}

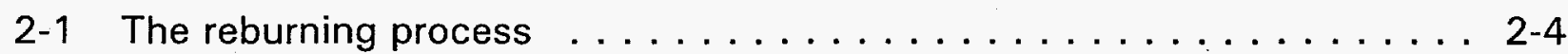

2-2 Schematic of GR-LNB process ................ 2-7

2-3 Technical approach to process design . . . . . . . . .33X. . 2.17

2-5 Impacts of GR on Cherokee Unit \#3 thermal profile and heat absorption . . . 2-20

2-6 GR predicted and field testing $\mathrm{NO}_{x}$ reductions on Hennepin Unit \#1 . . . . . . 2-22

2-7 Reburn zone stoichiometric ratio versus predicted and measured NOx reductions for Lakeside Unit \#7 . . . . . . . . . . . . . . . 2-23

2-8 GR predicted and field testing $\mathrm{NO}_{x}$ reductions on Lakeside Unit \#7 . . . 2-25

2-9 GR predicted and field testing $\mathrm{NO}_{x}$ reductions on Cherokee Unit \#3 . . 2 2-26

2-10 NO $\mathrm{NO}_{x}$ reduction performances of Cherokee GR-LNB modifications . . . . . 2-27

2-11 NO $\mathrm{NO}_{x}$ reduction performances of pilot unit and three GR demonstrations . 2-28

3-1 FlamemastEER ${ }^{\mathrm{TM}}$ low $\mathrm{NO}_{x}$ burner . . . . . . . . . . . . 3-5

5-1 Baseline $\mathrm{NO}_{x}$ versus furnace exit flue gas $\mathrm{O}_{2} \ldots \ldots \ldots \ldots \ldots \ldots$ 5-2

5-2 LNB baseline $\mathrm{NO}_{x}$ versus furnace exit flue gas $\mathrm{O}_{2} \ldots \ldots \ldots \ldots . . \ldots$ 5-4

5-3 LNB w/OFA NO $\mathrm{NO}_{x}$ versus primary zone stoichiometric ratio $\left(\mathrm{SR}_{1}\right) \ldots \ldots$ 5-7

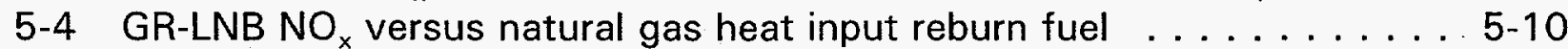

5-5 GR-LNB NO versus FGR flowrate . . . . . . . . . . . 5-12

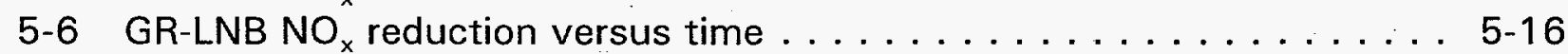

5-7 $\mathrm{NO}_{\mathrm{x}}$ versus load . . . . . . . . . . . . . . . . 5 5-18

5-8 LNB-Modified baseline $\mathrm{NO}_{x}$ versus furnace exit flue gas $\mathrm{O}_{2} \ldots \ldots \ldots$ 5-21

5-9 Second Generation GR-LNB NO versus gas heat input . . . . . . . . 5-23

5-10 First and Second Generation GR-LNB NO reduction versus time . . . . 5-24

5-11 GR-LNB $100 \%$ gas $w / G R N_{x}$ versus gas heat input . . . . . . . 5-27

7-1 The effect of unit size on the cost of $\mathrm{NO}_{x}$ reduction $\ldots \ldots \ldots \ldots .7-12$

7-2 The effect of capacity factor on the cost of $\mathrm{NO}_{x}$ reduction . . . . . 7-13

7-3 The effect of gas to coal price differential on the cost of NOx reduction 7-14

7-4 The effect of $\mathrm{SO} 2$ allowance price on the cost of $\mathrm{NO}_{x}$ reduction . . . 7-15 


\section{LIST OF ABBREVIATIONS}

$\begin{array}{ll}\text { CAAA } & \text { Clean Air Act Amendments } \\ \text { CCT } & \text { Clean Coal Technology } \\ \text { CRT } & \text { Cathode Ray Tube } \\ \text { EER } & \text { Energy and Environmental Research Corporation } \\ \text { EPA } & \text { Environmental Protection Agency } \\ \text { EPRI } & \text { Electric Power Research Institute } \\ \text { ESP } & \text { Electrostatic Precipitator } \\ \text { DOE } & \text { U. S. Department of Energy } \\ \text { FGD } & \text { Flue Gas Desulfurization } \\ \text { FGR } & \text { Flue Gas Recirculation } \\ \text { FWEC } & \text { Foster Wheeler Energy Corporation } \\ \text { GRI } & \text { Gas Research Institute } \\ \text { GR } & \text { Gas Reburning } \\ \text { GR-LNB } & \text { Gas Reburning w/low NO } \text { burners } \\ \text { HVT } & \text { High Velocity Temperature } \\ \text { NSPS } & \text { New Source Performance Standards } \\ \text { OFA } & \text { Overfire Air } \\ \text { OTR } & \text { Ozone Transport Region } \\ \text { PSCo } & \text { Public Service of Colorado } \\ \text { PSD } & \text { Prevention of Significant Deterioration } \\ \text { RACT } & \text { Reasonably Available Control Technology } \\ \text { SCR } & \text { Selective Catalytic Reduction } \\ \text { SNCR } & \text { Selective Non-Catalytic Reduction }\end{array}$




\section{LIST OF UNITS}

$\begin{array}{ll}\text { acfm } & \text { Actual Cubic Foot per Minute } \\ \text { Btu } & \text { British Thermal Unit } \\ { }^{\circ} \mathrm{F} & \text { Degree Fahrenheit } \\ \mathrm{ft}^{3} & \text { Cubic Foot } \\ \mathrm{gal} & \text { Gallon } \\ \text { in } & \text { Inch } \\ \mathrm{kW} & \text { Kilowatt } \\ \mathrm{kW} & \text { Kilowatt Electric } \\ \mathrm{kWhr} & \text { Kilowatt Hour } \\ \mathrm{lb} & \text { Pound } \\ \mathrm{lb} / \mathrm{hr} & \text { Pound per Hour } \\ \mathrm{MWe} & \text { Megawatt Electric } \\ \mathrm{psig} & \text { Pound per Square Inch (Gauge) } \\ \mathrm{TPY} & \text { Ton per Year } \\ \mathrm{W} . \mathrm{C} . & \text { Water Column } \\ 10^{6} \text { Btu } & \text { Million Btu } \\ " & \text { Inch } \\ \% & \text { Percent }\end{array}$


_GLOSSARY OF TERMS

$\begin{array}{ll}\mathrm{C}_{2} \mathrm{H}_{2} & \text { Acetylene } \\ \mathrm{C}_{2} \mathrm{H}_{4} & \text { Ethylene } \\ \mathrm{Ca}(\mathrm{OH})_{2} & \text { Calcium Hydroxide } \\ \mathrm{CH} & \text { Hydrocarbon Radical } \\ \mathrm{CH}_{2} & \text { Hydrocarbon Radical } \\ \mathrm{CH}_{4} & \text { Methane } \\ \mathrm{CO} & \text { Carbon Monoxide } \\ \mathrm{CO} & \text { Carbon Dioxide } \\ \mathrm{Fe} & \text { Iron } \\ \mathrm{H}_{2} & \text { Hydrogen (diatomic) } \\ \mathrm{H}_{2} \mathrm{~S} & \text { Hydrogen Sulfide } \\ \mathrm{H}_{2} \mathrm{O} & \text { Water } \\ \mathrm{N}_{2} & \text { Nitrogen (diatomic) } \\ \mathrm{NH}_{3} & \text { Ammonia } \\ \mathrm{NO}_{x} & \text { Nitrogen Oxides } \\ \mathrm{O}_{2} & \text { Oxygen (diatomic) } \\ \mathrm{S}_{\mathrm{SO}_{2}} & \text { Sulfur } \\ \mathrm{SO}_{2} & \text { Sulfur Dioxide }\end{array}$




\section{EXECUTIVE SUMMARY}

The purpose of the Guideline Manual is to provide recommendations for the application of combined gas reburning-low $\mathrm{NO}_{\mathrm{x}}$ burner (GR-LNB) technologies to pre-NSPS boilers. The manual includes design recommendations, performance (prediction versus field data), economic projections and comparisons with competing technologies. The report also includes an assessment of boiler impacts.

The site for the GR-LNB demonstration was PSCo's Cherokee Station, located in Denver, Colorado. Cherokee Unit \#3 was the host unit for the GR-LNB demonstration. It was constructed in 1962 and was not required to meet New Source Performance Standards required by the Clean Air Act Amendments (applies only to units constructed after 1971). The boiler is a balanced draft wall-fired unit, the original burners being Babcock and Wilcox flare-type PC burners. It has a rating of $172 \mathrm{MW}_{\mathrm{e}}$ gross, or $158 \mathrm{MW}_{\mathrm{e}}$ net. It fired pulverized western U.S. bituminous coal, with a sulfur content of $0.4 \%$ and an ash content of $10 \%$ through 16 burners on the front wall of the unit.

Low $\mathrm{NO}_{x}$ burners (LNBs) are designed to create less $\mathrm{NO}_{x}$ than conventional burners. However, the $\mathrm{NO}_{x}$ control achieved is normally in the range of $30-60 \%$ and typically $50 \%$. Also, at the higher $\mathrm{NO}_{\mathrm{x}}$ reduction levels, $\mathrm{CO}$ emissions tend to be above acceptable standards. Gas reburning (GR) is designed to reduce $\mathrm{NO}_{x}$ in the flue gas by staged fuel combustion. When combined, gas reburning and low $\mathrm{NO}_{x}$ burners work in harmony to minimize $\mathrm{NO}_{x}$ emissions and maintain acceptable levels of $\mathrm{CO}$ emissions. Several benefits are derived from adding gas reburning to LNBs:

- Low capital cost

- Compatibility with high-sulfur coal

- Incremental reduction in $\mathrm{SO}_{2}$ emissions, since natural gas contains no sulfur

- $\quad$ No adverse effects on boiler thermal performance

- Minimal system operating complexity 
The objective of the project was to demonstrate the commercial readiness of the GR-LNB technology for application to older pre-NSPS utility boilers. These older boilers have one of several common firing configurations with the wall-fired type being the most common. The specific goal was to demonstrate that high levels of $\mathrm{NO}_{x}$ reduction could be achieved over the long term with minor impacts on other areas of unit operation including combustion performance (quantified by unburned carbon-in-ash), furnace slagging or corrosion, convective pass fouling, steam capacity and final steam conditions, and other areas of unit performance. The target was a reduction of 70 percent in $\mathrm{NO}_{x}$ emissions.

This project, completed under the U.S. Department of Energy's Clean Coal Technology Program (Round 3), was sponsored by:

- U.S. Department of Energy (DOE)

- $\quad$ Gas Research Institute (GRI)

- $\quad$ Electric Power Research Institute (EPRI)

- Colorado Interstate Gas (CIG)

- Public Service Company of Colorado (PSCo)

- Energy and Environmental Research Corporation (EER)

\section{Process Design}

The technology is a co-application of two previously demonstrated technologies, GR and LNB. The co-application of GR and LNB yields greater $\mathrm{NO}_{x}$ emission reductions than either technology could achieve alone. LNBs reduce emissions of $\mathrm{NO}_{x}$ by staging the mixing of coal and air resulting in flame fuel-rich regions, longer flames, and lower peak flame temperatures. While $\mathrm{LNBs}$ reduce $\mathrm{NO}_{\mathrm{x}}$, they may yield higher levels of unburned carbon and $\mathrm{CO}$ emissions. This is the result of incomplete combustion due to burner staging of coal combustion (coal/air mixing). The LNB technology is standard, off-the shelf technology, so the emphasis in this report is placed more on the GR technology as it is integrated with the LNB technology. 
GR involves reducing the levels of coal and combustion air introduced through the primary burners and injecting natural gas above the burners (reburn zone). This is followed by the injection of overfire air (OFA) above the reburn zone. A reducing reburn zone is created in the boiler furnace wherein $\mathrm{NO}_{\mathrm{x}}$ created in the excess air primary zone is reduced to atmospheric nitrogen in the reburn zone. OFA is injection above the reburn zone to complete the combustion process. Each of these three zones has a unique stoichiometric ratio (SR, ratio of air to that theoretically required for complete combustion) as determined by the flow of coal, burner air, natural gas, and OFA. Flue gas recirculation (FGR) may be used to provide added momentum to the injected natural gas. FGR has a low $\mathrm{O}_{2}$ content and has a minor impact on the reburn and burnout zone SRs.

The process design for application of GR-LNB technology was developed using a methodology that involves the application of various experimental and analytical tools. Functional design requirements are based on the characteristics of the subject boiler, the GR-LNB process requirements, and the desired system performance goals. Process considerations that are essential to the design and practical application of the reburning system are: the reburn zone stoichiometric ratio, the temperature (or location) at which the natural gas is injected, the OFA injection location, and any impacts on boiler thermal performance. Rapid and complete mixing of the reburn fuel and OFA with the local furnace gases is critical to the successful application of the GR process.

Detailed information concerning the flow field of the subject boiler was developed by isothermal flow modeling. Flow visualization was accomplished using smoke and neutrally buoyant bubble injection. Velocity measurements were made within the model using hot wire anemometer and Kurtz probe instrumentation. The hot wire anemometer was used in combination with observations of yarn tufts to produce velocity and mass distribution profiles at various measurement planes in the model. Dispersion measurements were made to determine the degree of mixing at locations downstream of the proposed natural gas and OFA injectors. 
FGR was used initially in this demonstration to provide added momentum to the natural gas reburn fuel to achieve good furnace flue gas penetration. During long term testing, it was determined that the FGR had a minimal effect on $\mathrm{NO}_{x}$ emissions. The Cherokee Unit \#3 had a reburn zone residence time of $0.5 \mathrm{sec}$. which has been found to be sufficient in many applications to preclude the need for FGR. A second design was completed. The natural gas injectors were re-designed to increase the velocity of the injected gas (higher gas pressures were used) and the OFA ports were modified to enhance mixing. This technology is referred to as Second Generation Gas Reburning. FGR adds substantially to the capital cost of the GR system and also contributes slightly to increased superheat attemperation water spray rates. Elimination of $F G R$ is therefore an obvious benefit.

\section{Engineering Design}

Installation of a GR-LNB system involves retrofit of the equipment onto an existing boiler. Due consideration must be given to the design of the following items and areas:

- Supply of natural gas, pressure, piping size requirements

- Mass flow rate requirement for flue gas recirculation (if needed)

- Injector configuration vs. boiler structural constraints

- Cooling medium for injectors

- $\quad$ Existing burner throat size before LNB installation

- Existing windbox air pressure

- Boiler tubewall penetrations

- Equipment footprint

- Electrical power distribution

- Plant and instrument air

- $\quad$ Existing controls system 


\section{System Operation}

Control and monitoring of the GR-LNB system may be accomplished with any modern process control system. For the demonstration project a Westinghouse Electric Process Control WDPF system was used. The system consisted of a variable mix of functional units (drops) communicating freely and rapidly via the WDPF Data Highway. The WDPF sends and receives signals from various components in the GR-LNB system, in addition to interfacing with other microprocessors.

The First Generation GR system is composed of three integrated systems: (1) natural gas injection, (2) FGR, and (3) OFA injection. The natural gas flow rate is controlled to the desired value for optimum $\mathrm{NO}_{x}$ destruction. The FGR flow is controlled to a value to give the natural gas momentum for optimum distribution in the furnace. The OFA is controlled to a value to complete combustion of all unburned fuel leaving the reburning zone. The three integrated systems were interlocked, operated and monitored by the WDPF control system. In the Second Generation GR system the FGR control was eliminated.

\section{Technology Performance}

The new LNBs, installed by Foster Wheeler Energy Corporation (FWEC), reduced $\mathrm{NO}_{x}$ emissions from a pre-construction baseline of $0.73 \mathrm{lb} / 10^{6}$ Btu to $0.46 \mathrm{lb} / 10^{6} \mathrm{Btu}$ at $3.5 \% \mathrm{O}_{2}$. This was a reduction of $37 \%$ but below the target goal of $45 \%$. Also, carbon-in-ash and CO could not be maintained at acceptable levels.

When GR was introduced, the $\mathrm{NO}_{x}$ emissions level dropped to an average of $0.25 \mathrm{lb} / 10^{6}$ Btu at $3.25 \% \mathrm{O}_{2}$ providing an overall GR-LNB reduction of $66 \%$, or a $46 \%$ drop from the LNB only emissions. The gas heat input to accomplish this level of $\mathrm{NO}_{x}$ reduction was $18 \%$. With GR-LNB, both unburned carbon and CO emissions were at acceptable levels. 
Following installation of the Seeond Generation equipment, the system achieved similar reductions in $\mathrm{NO}_{x}$ emissions. The post-mod LNB's yielded a baseline $\mathrm{NO}_{\mathrm{x}}$ emission level of $0.41 \mathrm{lb} / 10^{6} \mathrm{Btu}$ at $3.5 \% \mathrm{O}_{2}$, but $\mathrm{CO}$ and unburned carbon were still high. When $\mathrm{GR}$ was introduced through the modified high velocity injectors (w/o FGR), the $\mathrm{NO}_{x}$ emissions level dropped to an average of $0.26 \mathrm{bb} / 10^{6} \mathrm{Btu}$ at $3.2 \% \mathrm{O}_{2}$ to provide an overall GR-LNB NO${ }_{x}$ reduction of $64 \%$ or a decrease of $37 \%$ from modified LNB only operation. The gas heat input to accomplish this level of $\mathrm{NO}_{x}$ reduction was $12.5 \%$. With the modified GR-LNB, both unburned carbon and $\mathrm{CO}$ emissions were also at acceptable levels. These tests confirmed that the Second Generation GR system, that excludes the need for FGR (an added capital cost), is also a very effective $\mathrm{NO}_{\mathrm{x}}$ control technique

The reburning zone operates at slightly fuel rich conditions. This suggests the possibility of increased tube wastage due to removal of the protective oxide layer and/or sulfide attack. Accordingly, the field evaluations included a comprehensive program of nondestructive (ultrasonic tube thickness) evaluations. The evaluations showed no evidence of increased tube wastage attributable to GR.

Although not considered a part of this project, the opportunity presented itself to perform testing with natural gas as the primary fuel coupled with gas reburning. The gas/gas reburning testing demonstrated a reduction in $\mathrm{NO}_{x}$ emissions of $43 \%\left(0.30 \mathrm{lb} / 10^{6} \mathrm{Btu}\right.$ reduced to $0.17 \mathrm{lb} / 10^{6} \mathrm{Btu}$ ) using $7 \%$ gas reburn heat input.

\section{Boiler Impacts}

In steam generating units, the heat released from the combustion of fuels is absorbed by heat exchangers with high efficiencies. GR operation can affect the thermal performance of the unit in two ways. First, GR affects the furnace heat release profile and second, GR operation changes local stoichiometric ratios and particulate loading resulting in minor changes in lower and upper furnace deposition patterns. The demonstrations showed that 
the overall impact of GR operation on the heat absorption profile was very minor. There was a reduction in thermal efficiency of approximately $0.8 \% @ 12.5 \%$ natural gas heat input due to the increased $\mathrm{H} / \mathrm{C}$ ratio of the natural gas compared to coal. A higher $\mathrm{H} / \mathrm{C}$ ratio translates to greater moisture (latent evaporation) heat loss to the atmosphere.

GR operation did not exacerbate slagging in the furnace. Long term operation of the GR system did not show any trend toward additional slagging or fouling beyond that which occurred when operating without GR in service. Some slagging was noted around the LNBs, but this was attributed to the abnormal functioning of the burners.

In the reburn zone, slag formed around some of the gas injection nozzles on a random basis. However, this did not cause a problem with the reburn gas injection system performance. The injection nozzles were designed with removable inspection covers and clean out ports to determine if the gas injection nozzle tips were plugged. Generally, no more than two gas nozzles per wall would be plugged at a time, and usually only one nozzle per wall would require slag removal. When a nozzle did become plugged, it was a simple matter to "rod" out the nozzle and remove the slag from the nozzle orifice.

In the OFA zone, heavy slag deposits formed around three of the six OFA injectors after about three months of operation. The slag formation was attributed to higher flue gas temperatures in this area with the GR in operation. The air injected through the OFA ports would "chill" the entrained molten ash particles so that they would stick and solidify at this location. The buildup of slag progressed over time due to a lack of sootblowers in this area of the furnace. Slag would build up on the refractory around the ports, and without sootblowers in place for removal, the deposits would continue to grow until a significant "eyebrow" would form and solidify around the port. These deposits were removed during regularly scheduled outages. 
results and the favorable results of two previous EER DOE-CCT projects involving GR, EER and the utility determined that tube wastage did not appear to be a problem.

\section{Economics}

The cost and performance data from the Cherokee project were used to estimate the costs of installation, operation and performance for commercial installation of GR-LNB onto a $300 \mathrm{MW}_{\mathrm{e}}$ power plant. The estimate is based on mature technology; i.e., a so-called "nth" plant which incorporates process improvements resulting from experience gained in earlier installations. The total cost for a Second Generation GR system, w/o FGR, including a $15 \%$ project contingency, is at $\$ 7.70$ million or $\$ 25.66 / \mathrm{kW}_{e}$ (1996 dollars). The GR and LNB system capital costs can be easily separated from one another for they are independent systems. The capital cost for the GR system only is estimated at $\$ 3.54$ million or $\$ 11.79 / \mathrm{kW}_{\mathrm{e}}$, and the LNB system capital cost is estimated at $\$ 4.16$ million or $\$ 13.87 / \mathrm{kW}_{\mathrm{e}}$.

EER conducted analyses to evaluate the fixed and variable (operating) costs of a GR system for a $300 \mathrm{MW}_{\mathrm{e}}$ coal wall-fired power plant (net heat rate of $10,000 \mathrm{Btu} / \mathrm{kWhr}$ before GR-LNB). The total annual incremental gross operating cost for the GR-LNB system, excluding fixed charges, is estimated at $\$ 2.59$ million. If an $\mathrm{SO}_{2}$ allowance credit is taken based on the reduction of fuel sulfur when firing natural gas, the net operating cost is estimated at about $\$ 2.10$ million. This $\mathrm{SO}_{2}$ credit was based on an allowance of $\$ 95 /$ ton (Feb. 1996). Variable operating cost for the GR-LNB is about $\$ 2.26$ million and the fixed cost, excluding fixed charges, is about $\$ 0.33$ million.

Based on the developed capital and fixed/variable operating costs, economic projections were made using current dollars which include an inflation rate of $4.0 \%$, and constant dollars which ignore inflation; see the table below. $\mathrm{NO}_{x}$ reduction $(64 \%$ or 3,990 TPY) costs were based on a $65 \%$ capacity factor for the unit with $12.5 \%$ of the heat input 


\section{GR-LNB PERFORMANCE AND ECONOMIC PROJECTIONS}

\section{Summary of Data}

\section{Power Plant Attributes}

Plant capacity, net

Power produced, net

Capacity factor

Plant life

Coal feed

Sulfur in coal

$$
\begin{gathered}
\text { Units } \\
\text { MWe } \\
10^{9} \mathrm{kWh} / \mathrm{yr} \\
\% \\
\mathrm{yr} \\
10^{6} \text { tons/yr } \\
\text { wt } \%
\end{gathered}
$$

Value

\section{Emissions Control Data}

Removal efficiency

Units

Value

Emissions standard (EPA 40CFR Part 76 - 12/19/96)

$\%$

Emissions without controls

$\mathrm{lb} / 10^{6} \mathrm{Btu}$

Emissions with controls

$\mathrm{lb} / 10^{6} \mathrm{Btu}$

0.73

Amount reduced

$\mathrm{lb} / 10^{6} \mathrm{Btu}$

Levelized Cost of Power

Current Dollars

Factor
0.160
1.314
1.314

1.314

Mills/kWhr

Capital Charge

Fixed O\&M Cost

Variable Operating Cost

Total Cost

$\mathrm{SO}_{2}$ Credits

Total Cost $w / \mathrm{SO}_{2}$ Credits

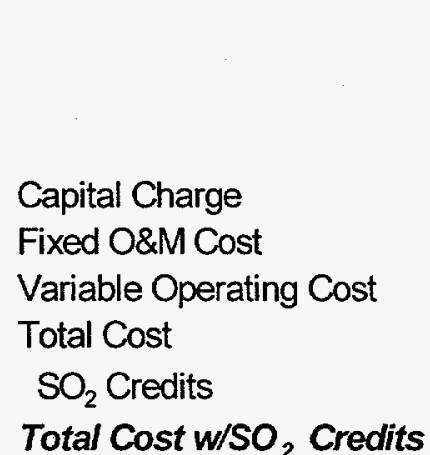

Total Cost w/SO $\mathrm{S}_{2}$ Credits
1.314

0.72

0.25

1.74

2.71

(0.37)

2.34

Levelized Cost--NOx Basis

Current Dollars

\$ton

Factor

0.160

Removed

309

109

1.314

1.314

1.314

\section{Constant Dollars}

Factor

0.124

1.000

1.000

1.000

1.79
0.56

0.19

1.32

2.07

Basis: $64 \%$ NOx reduction based on unit with 0.5 seconds reburn zone residence time

Constant Dollars

\$/ton

Factor

0.124

Removed

239

83

566

888

(122)

766
1.000

1.000 
supplied by natural gas at a gas to coal price differential of $\$ 1.00 /$ million Btu. The incremental increase in the levelized cost of power, including capital charges is estimated at $2.07 \mathrm{mills} / \mathrm{kWhr}$ in constant dollars and $2.71 \mathrm{mills} / \mathrm{kWhr}$ in current dollars.

If an $\mathrm{SO}_{2}$ credit is applied based on fuel sulfur reduction when firing natural gas, the net incremental increase in the levelized cost of power is estimated at $1.79 \mathrm{mills} / \mathrm{kWhr}$ in constant dollars and 2.34 mills $/ \mathrm{kWhr}$ in current dollars. The levelized cost of $\mathrm{NO}_{x}$ removal is estimated at $\$ 888 /$ ton and $\$ 1,161 /$ ton for the constant and current dollar projections, respectively. If an $\mathrm{SO}_{2}$ credit is applied based on fuel sulfur reduction, the net levelized cost of $\mathrm{NO}_{x}$ removal is estimated at $\$ 766 /$ ton and $\$ 1,001 /$ ton for constant and current dollar projections, respectively.

Based on the levelized cost (in constant dollars) for reducing nitrogen oxides, excluding $\mathrm{SO}_{2}$ credits, the capital charge component made up around $27 \%$ of the total cost of $\mathrm{NO}_{\mathrm{x}}$ reduction. The fixed operation and maintenance costs represented only $9 \%$, and the variable cost made up the $64 \%$ of the cost for removing $\mathrm{NO}_{\mathrm{x}}$. The variable operating cost is dominated by the differential price between natural gas and coal.

The economics developed for the $300 \mathrm{MW}_{\mathrm{e}}$ system were used to determine the economic effects of varying the selected parameters shown below:

- Fuel cost differential between gas and coal

- Wall-fired unit size

- Onstream capacity factor

- Sulfur dioxide allowance credits

The GR-LNB capital costs developed for a range of power plant sizes was based on scaling the power plant cost based on a 0.75 power factor. The effects of the above variables, including an annual $12.4 \%$ fixed charge rate, are discussed below. $\mathrm{NO}_{\mathrm{x}}$ reduction costs are based on constant dollars and include $\mathrm{SO}_{2}$ allowance credits. Of the 
four parameters that were varied, clearly the price of natural gas is the most dominant parameter regarding the cost of $\mathrm{NO}_{x}$ emission reductions.

Effect of plant size The size of plant on economics becomes less significant for unit sizes of $300 \mathrm{MW}_{\mathrm{e}}$ and greater. For example, the cost of $\mathrm{NO}_{\mathrm{x}}$ emissions for a $300 \mathrm{MW}_{\mathrm{e}}$ unit is $\$ 118 /$ ton less than a $150 \mathrm{MW}_{e}$ plant and when increasing the size to $450 \mathrm{MW}_{e}$ the cost is reduced only $\$ 56 /$ ton.

Effect of capacity factor The onstream capacity factor impact is linear. For example, the cost of $\mathrm{NO}_{x}$ emissions for a $55 \%$ capacity factor is $\$ 37 /$ ton more than that for $65 \%$ and when it increases from $65 \%$ to $75 \%$ the cost is reduced $\$ 33 /$ ton. These two values are not identical; linearity occurs with the ratio of the two capacity factors.

Effect of gas to coal price differential The price of natural gas has a linear effect on the $\mathrm{NO}_{x}$ reduction costs. For every $\$ 0.25 / 10^{6} \mathrm{Btu}$ change, either an increase or decrease in the gas to coal price differential, there is a corresponding $\$ 253 /$ ton cost effect.

Effect of $\mathrm{SO}_{2}$ allowance price The price of $\mathrm{SO}_{2}$ allowances also has a linear effect on the $\mathrm{NO}_{x}$ reduction costs. For every $\$ 50 /$ ton change, either an increase or decrease in price, there is a corresponding $\$ 64 /$ ton effect.

An independent study completed for the U.S. EPA (Contract No. 68-D2-0168) "Investigation of Performance and Cost of $\mathrm{NO}_{\mathrm{x}}$ Controls as Applied to Group 2 Boilers", compared the costs of competing $\mathrm{NO}_{x}$ control technologies. The Selective Non-Catalytic Reduction (SNCR) and Selective Catalytic Reduction (SCR) costs developed in this study were used for comparison with other $\mathrm{NO}_{\mathrm{x}}$ control technologies.

In the table that follows, the cost of Gas Reburning, Low NO Burners, Second Generation GR-LNB and Coal Reburning, developed by EER, were compared to the cost of SNCR and $S C R$, based on $\$ / \mathrm{kW}_{\mathrm{e}}$ and $\$ /$ ton of $\mathrm{NO}_{x}$ removed. The comparison is made for $300 \mathrm{MW}_{\mathrm{e}}$ wall-fired unit applications. The $\mathrm{NO}_{\mathrm{x}}$ control technologies show a cost per ton of $\mathrm{NO}_{\mathrm{x}}$ removed that ranges from approximately $\$ 230$ to $\$ 770$. Based on this comparison low $\mathrm{NO}_{x}$ burners are the least expensive. SNCR and GR-LNB are the most expensive. GR, coal 
reburning and SCR are similar when the price differential between the gas and the primary coal is $\$ 1.00 / 10^{6} \mathrm{Btu}$ (GR case).

$$
300 \mathrm{MW}_{\mathrm{e}} \text { WALL-FIRED NO} \times \text { CONTROL COMPARISON }
$$

\begin{tabular}{|c|c|c|c|}
\hline Technology & $\begin{array}{c}\mathrm{NO}_{x} \text { Reduced } \\
\%\end{array}$ & $\begin{array}{c}\text { Capital Cost } \\
\$ / k W_{e}\end{array}$ & $\begin{array}{c}\mathrm{NO}_{\times} \text {Removed } \\
\text { \$/ton } \\
\end{array}$ \\
\hline Gas Reburning ${ }^{1}$ (GR only) & 60 & 11.8 & $527^{6}$ \\
\hline Low $\mathrm{NO}_{x}$ Burners (LNBs only) & 45 & 13.9 & 227 \\
\hline GR $^{1}$-LNB (2nd Generation) & 64 & 24.6 & $766^{6}$ \\
\hline Coal Reburning ${ }^{2}$ & 50 & 28.0 & 592 \\
\hline $\mathrm{SNCR}^{3}$ & 35 & 9.0 & 700 \\
\hline $\mathrm{SCR}^{4}$ & 50 & 44 & 575 \\
\hline
\end{tabular}

(1) Natural Gas@ @ $\$ 2.47 / 10^{6}$ Btu and Coal @ $\$ 1.47 / 10^{6}$ Btu

(2) No added pulverizer requirement

(3) 50\% Urea solution @ \$0.75/gal

(4) Anhydrous Ammonia @ \$162/ton \& SCR catalyst replacement (3 yr life) @ \$350/ft ${ }^{3}$

(5) Base levelized costs using current dollars

(6) Includes a $\$ 95 /$ ton $\mathrm{SO}_{2}$ allowance credit

For $\mathrm{NO}_{\mathrm{x}}$ reduction beyond what is possible with one particular technology, it is possible to combine technologies for deeper reduction. Besides the GR-LNB technology, Advanced $G R$ is currently being developed and marketed by EER. It involves the simultaneous application of GR and SNCR. Overall $\mathrm{NO}_{x}$ reduction is expected to be in the range of 75 to 90 percent. 


\subsection{OVERVIEW}

\subsection{Purpose of the Report}

The purpose of the Guideline Manual is to provide recommendations for the application of

combined Gas Reburning and Low $\mathrm{NO}_{x}$ burners (GR-LNB) to utility boilers for obtaining deep $\mathrm{NO}_{x}$ reduction from utility boilers. The manual includes design recommendations, performance predictions versus actual field data, economic projections and comparisons with other competing deep $\mathrm{NO}_{\mathrm{x}}$ reduction technologies. The report also includes an assessment of boiler impacts.

\subsection{Basis of the Report}

A full-scale demonstration conducted as a part of the U.S. Department of Energy's Clean Coal Technology Program (Round 3) forms the basis of the Guideline Manual. The GRLNB demonstration was performed on Public Service of Colorado's (PSCo) Cherokee Unit \#3, located in Denver, Colorado. This unit is a $172 \mathrm{MW}_{\mathrm{e}}$ wall-fired boiler that fires low sulfur Colorado bituminous coal. The PSCo unit was larger than the previous units that demonstrated GR and provided an excellent design methodology scale-up test based on prior laboratory/pilot testing.

The objective of the project was to demonstrate the commercial readiness of the GR-LNB technology for application to older pre-NSPS utility boilers. These older boilers have one of several firing configurations, with the wall-fired type being the most common. The specific performance goal was to demonstrate that $\mathrm{NO}_{\mathrm{x}}$ reductions of $70 \%$ could be achieved with minor impacts on other areas of unit operation. This goal was achieved and showed that the pilot scale to full scale design methodology developed by EER was valid. 
Following design, installation and startup of the GR and LNB systems, optimum operational setpoints were established through a series of pre-planned parametric tests. Optimum conditions are defined as those providing the maximum benefit (reduction of $\mathrm{NO}_{\mathrm{x}}$ emissions) for the minimum cost (natural gas usage) when operating within established boiler constraints. Parametric testing was followed by normal operation for approximately one year.

\subsection{Reference Material}

For more details on this GR-LNB demonstration project, please refer to the following reports:

1) Evaluation of Gas Reburning and Low $\mathrm{NO}_{x}$ Burners on a Wall-fired Boiler "Design and Technical Performance Report"

2) Evaluation of Gas Reburning and Low $\mathrm{NO}_{x}$ Burners on a Wall-fired Boiler "Performance and Economics Report"

Prepared Under:

U. S. Department of Energy Cooperative Agreement DE-FC-91 PC90547 Gas Research Institute Contract No. 5090-254-1994

Electric Power Research Institute

Public Service Company of Colorado

Colorado Interstate Gas Company

Prepared by:

Energy and Environmental Research Corporation

For additional information, please refer to the technical papers listed in the references and the technical reports listed in the bibliography of this report. 
The technology evaluated for this demonstration was a combination of sequential $\mathrm{NO}_{\mathrm{x}}$ reduction techniques, low $\mathrm{NO}_{x}$ burners $(\mathrm{LNB})$ used in combination with Gas Reburning (GR). This project demonstration complemented two other full-scale GR demonstrations completed under a prior U.S. DOE CCT-1 program by EER. Previous demonstrations involved the co-application of $\mathrm{GR}$ with furnace sorbent injection $(\mathrm{SI})$ for reducing both $\mathrm{NO}_{\mathrm{x}}$ and $\mathrm{SO}_{2}$ emissions at the following sites:

- $\quad$ Illinois Power (Hennepin, IL)

Hennepin Station Unit 1

$80 \mathrm{MW}_{\mathrm{e}}$ (gross) tangentially-fired unit

GR reduced $\mathrm{NO}_{x}$ by $67 \%$ using $18 \%$ gas heat input

- $\quad$ City Water Light and Power (Springfield, IL)

Lakeside Station Unit 7

$33 \mathrm{MW}_{\mathrm{e}}$ (gross) cyclone-fired unit

GR reduced $\mathrm{NO}_{x}$ by $66 \%$ using $22 \%$ gas heat input

The GR-LNB demonstration was performed on Public Service of Colorado's (PSCo) Cherokee Unit \#3, located in Denver, Colorado. This unit is a $172 \mathrm{MW}_{\mathrm{e}}$ (gross) wall-fired boiler that uses Colorado bituminous, low-sulfur coal. The PSCo unit was larger than the previous units where GR was demonstrated and provided an excellent scale-up demonstration from laboratory testing. The target for the project was a reduction of 70 percent in $\mathrm{NO}_{x}$ emissions.

The gas reburning system was designed by EER and the low $\mathrm{NO}_{x}$ burners were provided by Foster Wheeler Energy Corporation. Based on the successful results of the program, the installed GR-LNB equipment was retained by PSCo. 
The co-application of GR and LNB yields a higher $\mathrm{NO}_{x}$ emissions reduction than either technology could achieve alone. LNBs reduce $\mathrm{NO}_{x}$ by 30 to $50 \%$, while GR nominally achieves a $60 \%$ reduction. The target $\mathrm{NO}_{x}$ reduction for this demonstration was $70 \%$. EER's portion of this work related to the GR system performance when used in combination with low $\mathrm{NO}_{x}$ burners. Since the burners were provided by Foster Wheeler Corporation, the EER GR system is stressed and addressed more comprehensively within this report than the low $\mathrm{NO}_{x}$ burners.

\section{$2.1 \quad$ Gas Reburning}

Gas Reburning (GR) is a very flexible $\mathrm{NO}_{\mathrm{x}}$ reduction technology that can be run in several ways to provide varying degrees of $\mathrm{NO}_{x}$ reduction. The GR-LNB system can be operated under three modes of operation.

\subsubsection{Modes of Operation}

Baseline mode with no reburn fuel Under this condition, although no reburn fuel is being added, there are low rates of cooling air flowing around the gas injectors and through the overfire ports. Based on maintaining the same oxygen level in the flue gas exiting the furnace as for the pre-GR-LNB application, a slight air staging occurs that will reduce $\mathrm{NO}_{\mathrm{x}}$ emissions slightly compared to pre-GR-LNB retrofit emissions. Carbon burnout under this mode of operation will be very similar to the pre-GR-LNB retrofit.

Overfire air (OFA) only By adding overfire air without the use of reburn fuel, staged combustion can be put into place to reduce $\mathrm{NO}_{\mathrm{x}}$ emissions. In this mode of operation, as the overfire air rate is increased, the air rate to the primary burners automatically decreases to maintain the $\mathrm{O}_{2}$ set point at the exit of the boiler economizer. 
With a reduced air rate to the burners, the localized burner zone becomes hotter which has the tendency to increase $\mathrm{NO}_{x}$ production under oxidizing conditions, but since there is less fuel being fired through the burners a greater percentage of heat is absorbed in the furnace walls that would cool the burner zone. Even if the localized temperatures increase, the temperature mechanism for increasing $\mathrm{NO}_{\mathrm{x}}$ emissions is more than offset by the reduced partial pressure of the oxygen in the burner zone. The lower the partial pressure of oxygen, the lower the $\mathrm{NO}_{\mathrm{x}}$ production, and in the burner zone the oxygen concentration is controlling.

With this type of staged combustion approach, overfire air is added at a point downstream of the burners where the flue gas is cool enough to minimize the production of thermal $\mathrm{NO}_{\mathrm{x}}$. With deeper staging (lowering of excess air levels in the primary burner zone) $\mathrm{NO}_{\mathrm{x}}$ emissions will reduce. The degree of staging is partially limited by the potential for higher corrosion in the hot burner zone due to higher $\mathrm{CO}$ concentrations; the deeper the staging the greater the potential for corrosion.

The other limiting factor is the carbon in the fly ash which increases with deeper staging. High carbon in ash could affect the ability of the utility to sell its fly ash to the cement industry. Overall $\mathrm{NO}_{x}$ reduction using a near optimum overfire air addition rate, taking into consideration the concerns delineated above, will yield approximately a $35 \%$ reduction compared to pre-GR retrofit operation.

Reburn mode Under full GR implementation, the combustion process is divided into three zones as illustrated in Figure 2-1. In the primary zone, the main fuel is fired through conventional burners but at a reduced rate to compensate for the reburning fuel which is injected downstream. In the reburning zone, injection of the reburning fuel consumes the excess air (oxygen) from the primary zone, producing a slightly fuel rich region where $\mathrm{NO}_{\mathrm{x}}$ is reduced by reactions with hydrocarbon radicals, carbon monoxide and hydrogen. Flue gas recirculation (FGR) may be used to provide momentum to the natural gas injection. 


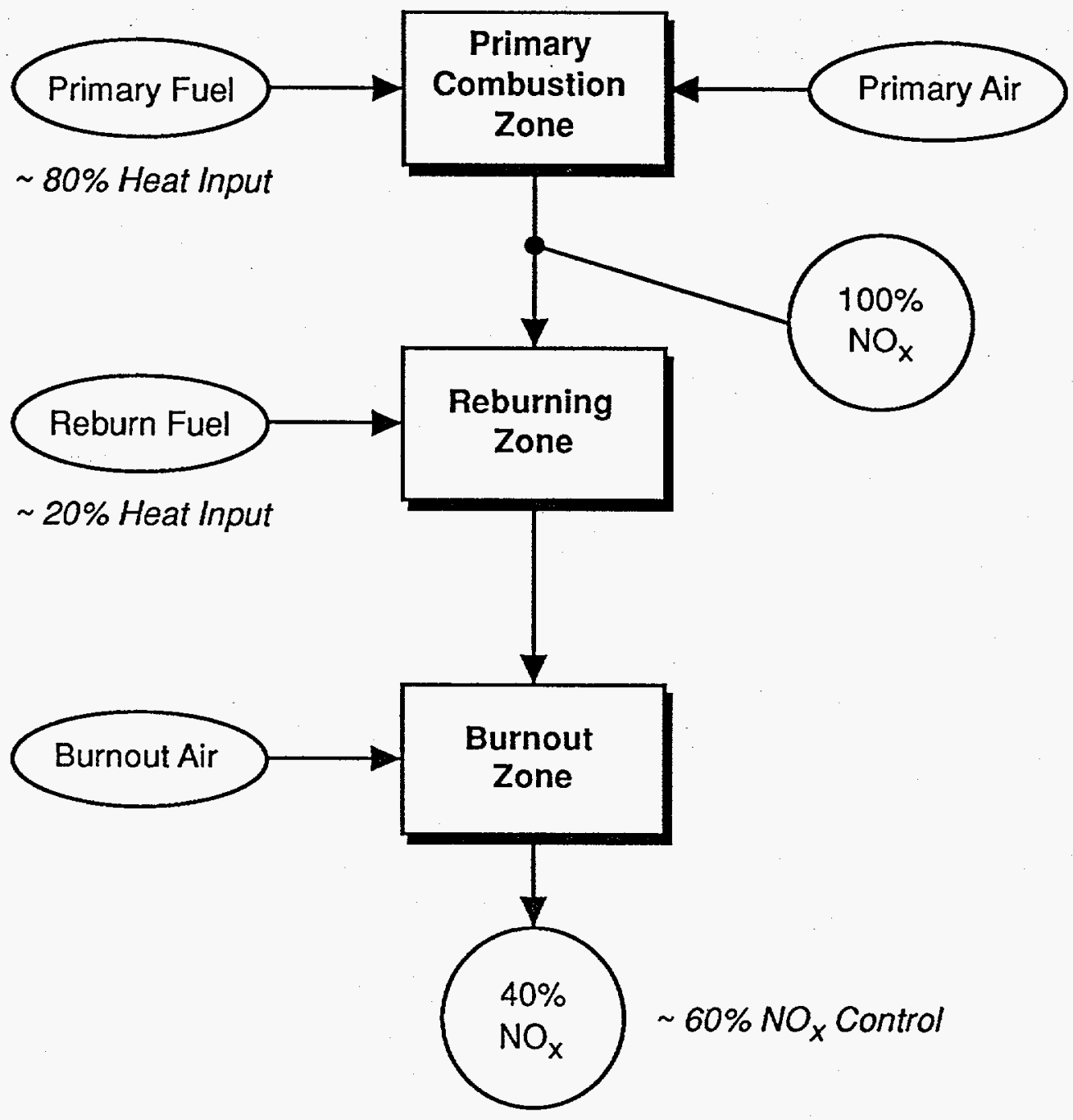

Figure 2-1. The reburning process 
FGR has a low $\mathrm{O}_{2}$ content and therefore has a minor impact on reburning and burnout zone stoichiometric ratios. OFA is added in the burnout zone to complete the combustion of the fuel gases produced in the reburning zone and to adjust the overall excess air to yield good carbon burnout. Thus, except for relatively minor changes in boiler efficiency, the total heat input to the furnace is the same as baseline operation, but is divided into two fuel streams. Similarly, the total air supplied to the furnace remains essentially unchanged but is divided into two streams, supplying air to the conventional burners and also to the OFA ports.

The three zones are described in more detail as follows:

- Primary (burner) Zone: Coal is fired at a rate corresponding to 75 to 90 percent of the total heat input, under low excess air $\left(S R=1.05\right.$ to 1.15). $\mathrm{NO}_{x}$ emissions in this zone are reduced by the lower heat release and the reduced oxygen concentrations.

- Reburn Zone: Reburn fuel (natural gas in this case) injection creates a fuel rich region wherein hydrocarbon fragments $\left(\mathrm{CH}, \mathrm{CH}_{2}\right.$, etc.) and carbon monoxide and hydrogen are formed which react with $\mathrm{NO}_{x}$, reducing it to diatomic or atmospheric nitrogen. In most applications the best reburning zone stoichiometric ratio is approximately 0.90 , achieved by injecting natural gas at a rate corresponding to about 15 to 20 percent of the total heat input. FGR may be injected with the natural gas to provide for better penetration and mixing with the furnace flue gas.

- Burnout (exit) Zone: OFA is injected higher up in the furnace to complete the combustion. OFA is typically 20 percent of the total air flow; a minimum excess air of 15 percent in maintained. OFA injection is optimized to minimize $\mathrm{CO}$ emissions and unburned carbon-in-fly ash.

With the GR system, natural gas is routed to the reburning zone of the boiler and is introduced into the boiler gas stream through a series of injection nozzles. The flow rate of gas to the reburn injectors is controlled automatically by the boiler operation control system. FGR, if used, is extracted from the boiler backpass, enhanced by a booster fan 
and injected simultaneously with the natural gas. To complete the fuel combustion, air at 500 to $600^{\circ} \mathrm{F}$ is extracted from the secondary air duct or windbox and is injected into the boiler downstream of the reburning zone through a series of OFA injection nozzles (see the GR-LNB schematic Figure 2-2). With GR, depending on initial $\mathrm{NO}_{x}$ concentrations and reburn zone residence time, $\mathrm{NO}_{x}$ reductions of 60 to $75 \%$ may be achieved.

A minimal flow of hot secondary air is maintained though the OFA injection nozzles when the GR system is not in service to keep the OFA nozzles cool and ambient air is used to cool the gas injection nozzles.

\subsubsection{GR Process Design Guidelines}

Since reburning requires no physical changes to the main combustion system, it can be applied to furnaces with virtually any firing configuration and fuel. The reburning process can be applied to all types of firing equipment including cyclone, tangential, wall, and stoker coal fired boilers. In addition, reburning can be applied to furnaces fired with any fossil fuel (coal, oil, gas, etc.). Reburning can also be applied to municipal waste incinerators, industrial boilers, and a range of industrial process furnaces.

The variables to be considered for an effective retrofit of a GR system to an existing utility boiler are many, see Table 2-1. First of all, baseline $\mathrm{NO}_{x}$ must be determined and the desired level of $\mathrm{NO}_{x}$ reduction must be set. An evaluation must be made concerning the boiler configuration as input into determining the available residence times for the Reburn and OFA zones. A detailed boiler inspection is required to determine any physical constraints imposed regarding the locations of the gas reburn piping, OFA ducting, and reburn and OFA injectors. 


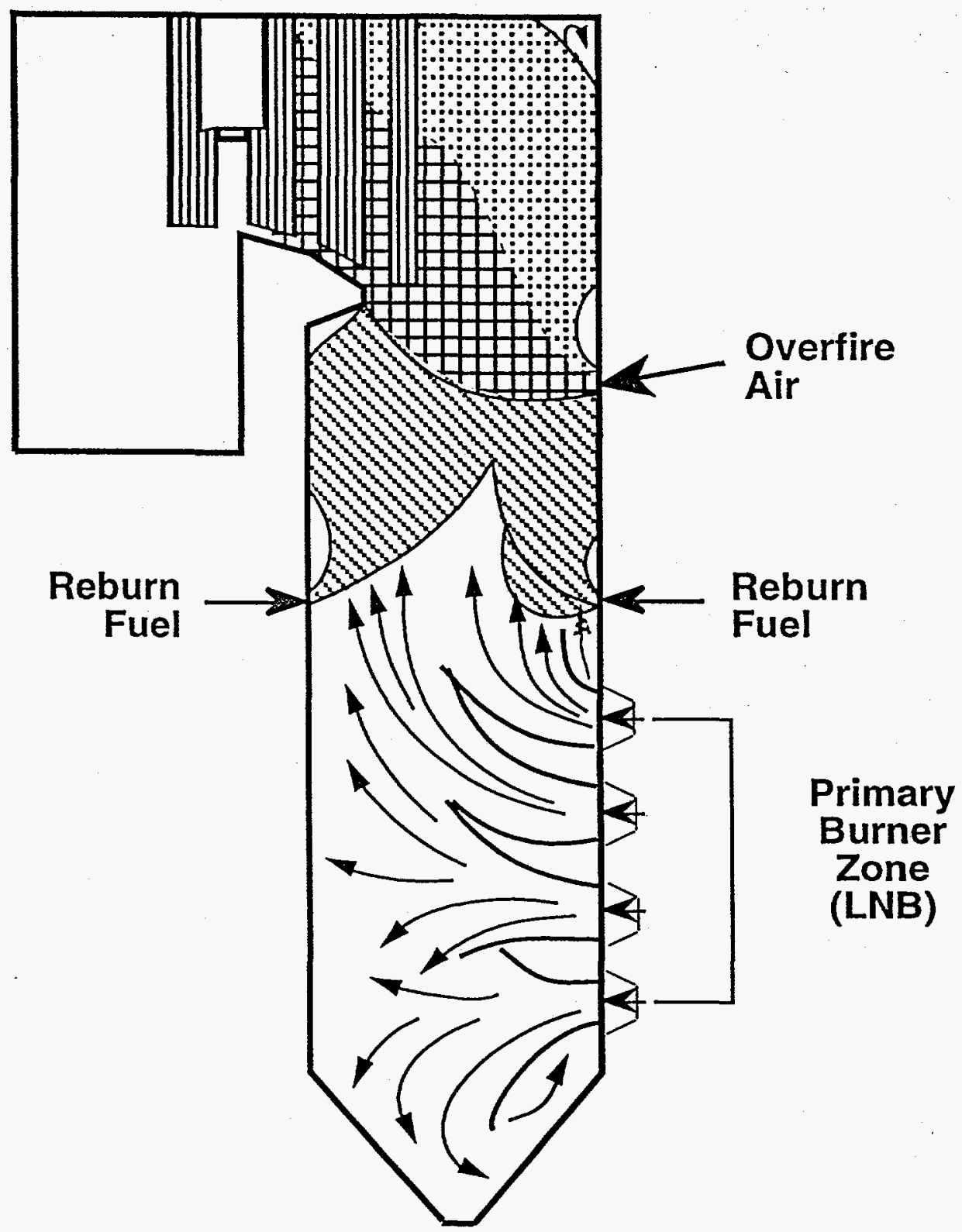

Figure 2-2. Schematic of GR-LNB Process 
TABLE 2-1. GR DESIGN GUIDELINES

\begin{tabular}{|c|c|c|c|}
\hline Parameter & Units & Value & Comments \\
\hline Primary Stoichiometry & SR & $\sim 1.10$ & $\begin{array}{l}\text { As low as possible } \\
\text { commensurate with good } \\
\text { lower furnace performance } \\
\text { and good carbon burnout }\end{array}$ \\
\hline $\begin{array}{l}\text { Reburn Injector } \\
\text { Vertical Location }\end{array}$ & NA & $\begin{array}{l}\text { Maximum temperature zone } \\
\text { above burners }\end{array}$ & $\begin{array}{l}\text { Primary burner fuel } \\
\text { combustion must be } \\
\text { essentially complete }\end{array}$ \\
\hline Reburn gas flow & $\begin{array}{l}\% \text { of total } \\
\text { heat input }\end{array}$ & $\sim 18$ & $\begin{array}{l}\text { Design for a maximum of } \\
25 \% \text { for flexibility }\end{array}$ \\
\hline $\begin{array}{l}\text { Reburn zone } \\
\text { Stoichiometry }\end{array}$ & SR & $\sim 0.90$ & $\begin{array}{l}\text { Varies with gas injection } \\
\text { rate to control } \mathrm{NO}_{\mathrm{x}} \text { and } \\
\text { primary burner zone SR }\end{array}$ \\
\hline Reburn injector array & NA & $\begin{array}{l}\text { Rapid and complete mixing } \\
\text { across furnace cross section }\end{array}$ & Site specific design \\
\hline $\begin{array}{l}\text { Reburn gas } \\
\text { carrier fluid }\end{array}$ & NA & $\begin{array}{l}\text { Flue gas recirculation (FGR) } \\
\text { is preferred }\end{array}$ & $\begin{array}{l}\text { Carrier gas with zero } \\
\text { oxygen is the best, FGR, } \\
\text { low in } \mathrm{O}_{2} \text { is the most cost } \\
\text { effective }\end{array}$ \\
\hline $\begin{array}{l}\text { Reburn zone } \\
\text { residence time }\end{array}$ & Sec. & $\begin{array}{l}0.25 \text { minimum } \\
0.50 \text { and up is best }\end{array}$ & $\begin{array}{l}\text { Above } 0.50 \text { sec., FGR may } \\
\text { not be required }\end{array}$ \\
\hline $\begin{array}{c}\text { Overfire air } \\
\text { (OFA) vertical position }\end{array}$ & NA & $\begin{array}{l}\text { Located as high in the } \\
\text { furnace as possible with } \\
\text { complete combustion prior to } \\
\text { convective pass entry }\end{array}$ & Site specific design \\
\hline $\begin{array}{l}\text { Overfire air } \\
\text { (OFA) injector array }\end{array}$ & NA & $\begin{array}{l}\text { Rapid and complete mixing } \\
\text { across the furnace cross } \\
\text { section }\end{array}$ & Site specific design \\
\hline $\begin{array}{l}\text { Overfire air } \\
\text { (OFA) zone }\end{array}$ & SR & 1.15 to 1.20 & $\begin{array}{l}\text { Sufficient to achieve } \\
\text { baseline flue gas } \mathrm{O}_{2} \\
\text { May be adjusted to affect } \\
\text { carbon burnout }\end{array}$ \\
\hline
\end{tabular}


Primary Zone The low $\mathrm{NO}_{\mathrm{x}}$ burners in the primary zone are operated in a normal manner. However, the burners should be operated in a balanced mode and with the lowest excess air commensurate with acceptable lower furnace performance considering flame stability, carbon in ash, flame impingement and waterwall corrosion. Typically the optimum air for burner operation with GR is a rate that provides for about a $10 \%$ excess air condition in the primary zone.

Reburning Zone The reburn fuel injectors should be located above the uppermost row of burners. Optimum performance is achieved by positioning the injectors at the highest possible temperature (which means a location closest to the burners) where the burner fuel combustion is essentially complete. This point can be established by field testing using infurnace measurements to establish $\mathrm{O}_{2}, \mathrm{CO}$ and carbon in ash augmented by visual flame inspection through available ports. Optionally, or in addition to this empirical approach, the burner flame zones can be analytically modeled. It may also be necessary to make some adjustments to the vertical location of the injectors to avoid buckstays, platforms or other interferences external to the boiler.

It is assumed that the objective of each utility, based on economics, will be to achieve the maximum possible $\mathrm{NO}_{x}$ reduction with the least amount of gas reburn fuel. The optimum condition for achieving this typically occurs when the rate of reburn fuel is set to yield about a 0.90 stoichiometric air/fuel ratio in the reburn zone. Based on the $10 \%$ excess air example for the primary zone, a $90 \%$ theoretical air in the reburn zone will require a reburn fuel rate that provides about $18 \%$ of the total boiler fuel input. To provide a margin of comfort regarding the optimum rate, the system should be designed to handle somewhat more gas flow, say $25 \%$. It should be recognized that the gas flow rate is a variable and will be adjusted during operation as $\mathrm{NO}_{x}$ control needs vary; higher gas rates yield higher $\mathrm{NO}_{\mathrm{x}}$ reductions and vice versa. 
Once the vertical position for the gas injectors has been established, the injector array can be designed. The injectors must be designed to achieve uniform and complete mixing of the reburn gas across the full boiler cross section. The rate of mixing should be accomplished in minimum time so as to maximize reburn zone residence time. The variables to adjust to achieve this include the number and position of reburn injectors and injection design parameters (mass flow rate of gas and any carrier gas, injection velocity, and injection angle). A number of analytical and empirical techniques are used to design the injector array; see Section 2.1.3.

A carrier gas, such as FGR, in certain applications can help to maximize the $\mathrm{NO}_{\mathrm{x}}$ reductions of a GR system. Two injection techniques were demonstrated, one using FGR with low pressure natural gas and one using a high pressure natural gas injector without FGR. Carrier gas is used to increase the penetration and rate of mixing of the natural gas throughout the reburn zone. A carrier gas may be required to provide adequate penetration in large furnace boxes or for applications where the reburn zone residence times are short $(<0.50 \mathrm{sec}$.$) .$

The carrier gas has the following impacts on reburning:

- $\quad$ Provides rapid and effective mixing, the momentum of the injected gas can be enhanced by injecting the gas along with a carrier medium.

- Oxygen in the carrier medium is deleterious to reburn performance. The reason is that optimum $\mathrm{NO}_{x}$ reduction is achieved under fuel rich conditions. As oxygen is added to the reburn zone via the carrier gas, additional reburn gas must be injected to consume this oxygen. This can result in a significant increase in the amount of natural gas required to achieve a specific $\mathrm{NO}_{x}$ emissions level. Since the natural gas cost is the most significant component of the operating cost, this has the potential to adversely affect economics. Three carrier mediums can be considered: air, steam and flue gas. Air has $21 \% \mathrm{O}_{2}$ and therefore is a poor choice based on gas consumption. Similarly a reburn injector, configured as a burner with air injected along with the fuel, requires more gas. Steam doesn't introduce $\mathrm{O}_{2}$; however, it has to be produced which requires both energy and water 
treatment. Flue gas is typically the best carrier medium. It has low $\mathrm{O}_{2}$ (typically $3 \%$ ) and requires no energy to produce. It does require a dust collector, fan and duct work.

- Provides the advantage of being able to control injection parameters independent of the natural gas flow. Typically, the FGR carrier flow rate significantly exceeds the gas flow rate. Therefore as the gas flow rate varies, the injection velocity and flow rate are nearly constant. This allows for good mixing of the reburn fuel with the furnace gases as the natural gas flow is turned down. Alternately, by varying the carrier medium flow, mixing conditions can be adjusted independent of the gas injection rate. This provides operational flexibility.

The reburn zone residence time is also an important GR design parameter. Residence time refers to the time of passage of combustion products flowing through the reburn zone from the point of gas injection to the point of overfire air injection. Once the gas has been mixed with the flue gas, most of the $\mathrm{NO}_{x}$ reduction occurs within 100 milliseconds.

Although $\mathrm{NO}_{x}$ reduction reactions occur rapidly, due to limited mixing rates, longer residence times result in additional $\mathrm{NO}_{x}$ reduction. Allowing for mixing times, a residence time on the order of 0.25 seconds is adequate to achieve good performance (this was the residence time available for the CCT-1 GR demonstration on CWLP's 33 MWe cyclonefired unit. A residence time of 0.50 seconds and greater provides for good $\mathrm{NO}_{x}$ reduction performance. Cherokee Unit \#3 had a reburn zone residence time of 0.50 seconds.

EER uses a $\mathrm{NO}_{x}$ model to calculate the $\mathrm{NO}_{x}$ reduction for a specific application. It is applied considering the finite mixing rates. It should be noted that in some boilers there is significant flow separation. For example in the cyclone unit tested in this program at CWLP, a large recirculation region was present in the upper furnace. The residence time of concern for reburning is the residence time passing through the non-separated region.

Overfire Air The vertical position of the overfire air ports is established by balancing the need to maximize reburn zone residence time (which suggests ports higher in the furnace) 
and the need to ensure complete combustion prior to the convective pass (which suggests ports lower in the furnace). An oxidation model is applied to evaluate the conditions necessary to essentially complete combustion prior to the convective pass.

The overfire air injection rate should be sufficient to raise the stoichiometric ratio of the combustion products to an excess air condition typical of baseline operation ( $3-4 \%$ excess $\mathrm{O}_{2}$ ). It should be noted that in a conventional single stage combustion system, the overall excess air is the same as the burner excess air. In such a system, the operating excess air is established by the operators considering its impact on burner performance, ash deposition in the lower and upper furnace, steam temperature and carbon burnout.

In a reburning system, the burner performance is de-coupled from the overall excess air. This provides the boiler operators with enhanced flexibility to adjust overfire air. By designing an overfire air system for rapid and complete mixing, it may be possible to operate the unit at excess air levels lower than baseline while still achieving good carbon burnout.

Once the vertical position has been established, the overfire air injector array can be designed. The overfire air injector performance impacts carbon burnout and more specifically the minimum excess $\mathrm{O}_{2}$ necessary to achieve burnout.

The overfire air injectors must be designed to achieve uniform and complete mixing of the overfire air across the full boiler cross section in minimum time. The variables to adjust to achieve this include the number and position of the overfire air injectors, and injection parameters (injection velocity and injection angle). A number of analytical and empirical techniques can be used to design the injector array as indicated in Section 2.1.3 that follows. 


\subsubsection{GR Process Design Tools}

The design of the GR-LNB system was completed according to a standardized methodology developed by EER. It includes the use of tools such as an isothermal physical flow model, computational heat transfer model, and kinetics ( $\mathrm{NO}_{x}$ reduction) model. The overall approach to the GR system design is illustrated in Figure 2-3.

The process design began with a site characterization of the host unit in a brief field test. The data generated in this test included emissions (normal $\mathrm{NO}_{x}$ and $\mathrm{O}_{2}$ levels), furnace gas temperatures, velocity measurements at available monitoring ports, and detailed boiler operating and steam cycle data. An extensive pre-exisiting data base and field data formed the basis for developing preliminary GR process and injector specifications.

A two or three dimensional heat transfer code was then used to evaluate the impacts of $\mathrm{GR}$ on the boiler gas temperature profile and heat transfer characteristics. The heat transfer code in conjunction with a boiler performance code were used to evaluate the mean gas temperature profile, heat absorptions by the heat exchangers, temperatures of the heat exchanger surfaces, steam generation rate, and final steam temperature.

A reduced scale isothermal physical flow model was built and fitted with the preliminary GR injection scheme. The natural gas/FGR and OFA injector configurations were evaluated for dispersion and mixing and optimized for these parameters through an iterative procedure. After flow rates and injection details of the reburn fuel and OFA were finalized, the kinetics code was run to predict the final $\mathrm{NO}_{\mathrm{x}}$ level. The process design was completed by evaluating potential impacts on various areas of boiler performance such as slagging, fouling, tubewall wastage, baghouse performance, ash disposal, and overall auxiliary power consumption cost impacts. 


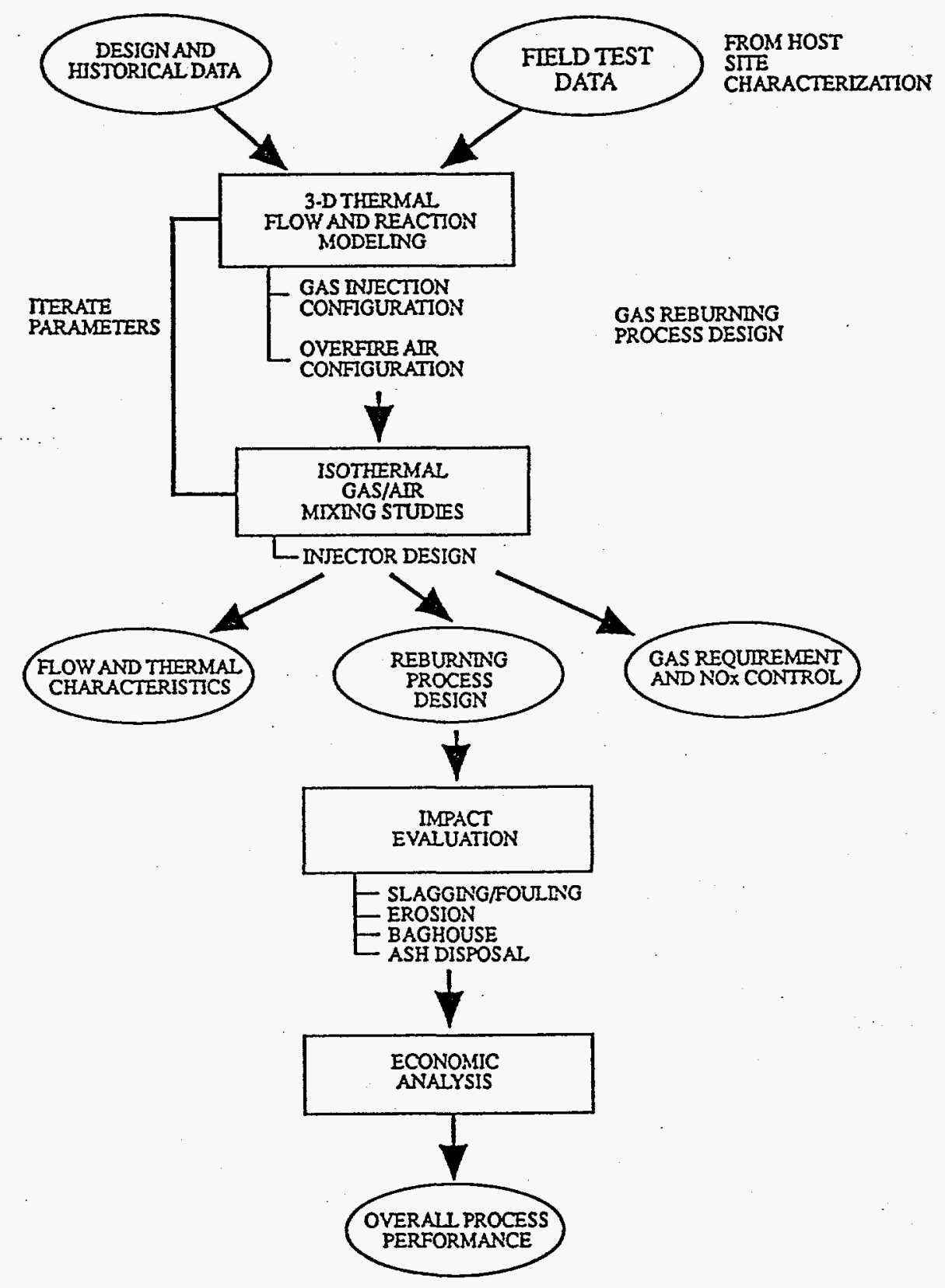

Figure 2-3. Technical approach to process design 
A $1 / 15$ scale isothermal physical flow model of the Cherokee Unit \#3 boiler was constructed. The model was of Plexiglas construction and was designed to match the velocity profile and pressure drop coefficient of each heat exchanger to those of the full-scale unit. The injection configurations for the reburn fuel with FGR and OFA were evaluated for dispersion and mixing using visual and tracer dispersion mapping techniques. Visual jet mixing patterns were observed using smoke and neutrally buoyant soap bubbles. Tracer dispersion was determined through injection of methane and final tracer mapping at selected planes of interest.

A two dimensional steady state heat transfer code was used to evaluate the impacts of GR on the heat transfer characteristics. The model divided the furnace into a grid of radial/axial zones. The heart of the code was a radiation heat transfer model which used a semistochastic approach to follow the radiative beams through the processes of emission, reflection and absorption within a prescribed numerical tolerance. The model also calculated convective heat transfer in the sections of the boiler where radiation heat transfer was dominant. The boiler performance code developed a steam side energy balance, but also calculated flue gas side temperature changes in parts of the boiler where convective heat transfer dominated. The output of both of the codes was the mean gas temperature profile in the furnace, heat absorption by each heat exchanger, temperature of deposit surfaces, and impacts on steam flow rate and temperature.

A $\mathrm{NO}_{x}$ control code was run using the temperature profile and mixing rate data as inputs. This code was programmed with the kinetics of chemical reactions involved in hydrocarbon combustion and fixed nitrogen reactions to yield final predicted $\mathrm{NO}_{\mathrm{x}}$ emissions/reductions. This code includes 200 fundamental reactions and has been extensively validated with field measurements. 


\subsubsection{GR Comparison of Theory with Practice}

In three electric utility retrofits, GR has been applied to boilers with very different gross capacities and firing arrangements: an $80 \mathrm{MW}_{\mathrm{e}}$ tangentially fired unit, a $33 \mathrm{MW}_{\mathrm{e}}$ cyclonefired unit, and a $172 \mathrm{MW}_{\mathrm{e}}$ wall-fired unit, see Figure 2-4. The results of these demonstrations have largely validated the design methodology and have provided insight into the influence of $\mathrm{GR}$ on $\mathrm{NO}_{x}$ emissions and boiler performance. In all three cases, $\mathrm{NO}_{x}$ control goals have been met or exceeded.

Due to the substantial design differences among boilers and furnaces, reburning must be custom designed to match site specific factors. The objective of EER's design methodology is to develop a site specific reburning system that maximizes the $\mathrm{NO}_{x}$ control potential of the system taking into account site specific constraints, and to project the impacts of the design on $\mathrm{NO}_{x}$ emissions and boiler performance.

Under U.S. DOE CCT projects, EER applied Gas Reburning to three coal fired utility boilers. The site specific GR designs are discussed below.

\section{Hennepin Station Unit \#1}

An integrated gas reburning-sorbent injection (GR-SI) system was designed for Illinois Power's Hennepin Station Unit \#1. Unit\#1 is tangentially fired with three burner elevations. It has a nominal capacity of $80 \mathrm{MW}_{\mathrm{e}}$ (gross).

The GR system was designed to operate with or without the SI system in operation. The Hennepin furnace had good access between the upper row of burners and the furnace nose. This allowed the GR system to be designed with a reburning zone residence time of 0.55 seconds. The reburning fuel was injected along with FGR through tilting nozzles on the furnace walls near the corners at the top of the windbox. The overfire air ports were located on the furnace walls near the corners below the nose. 


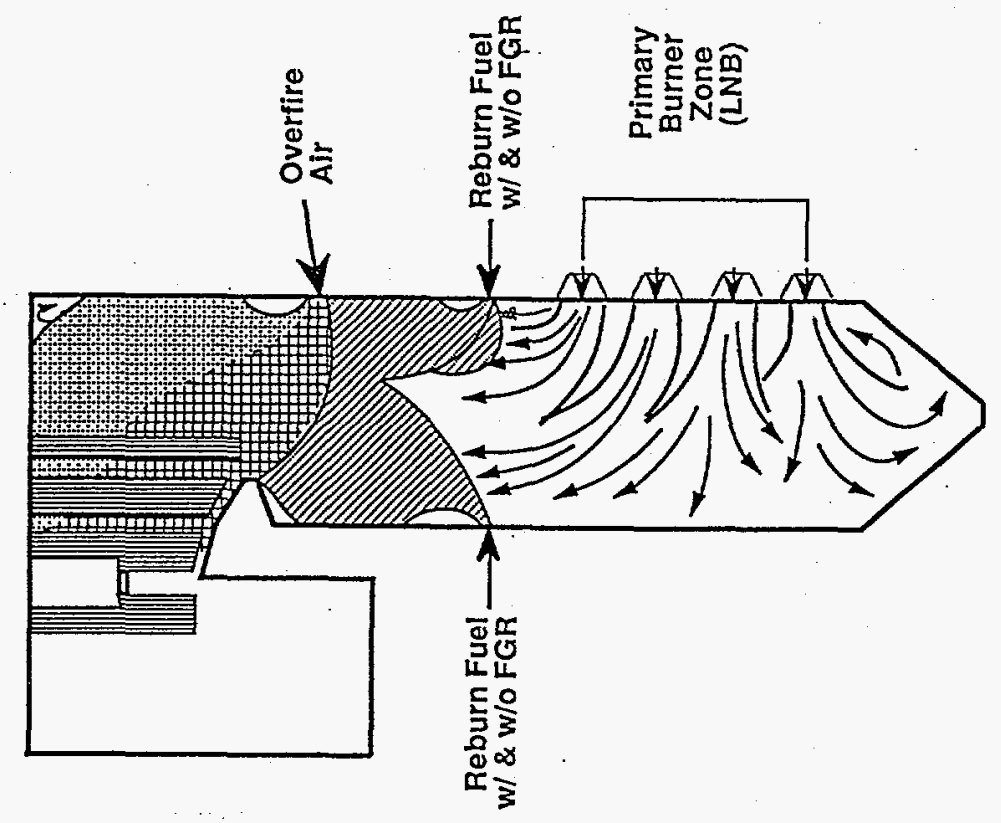

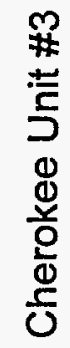
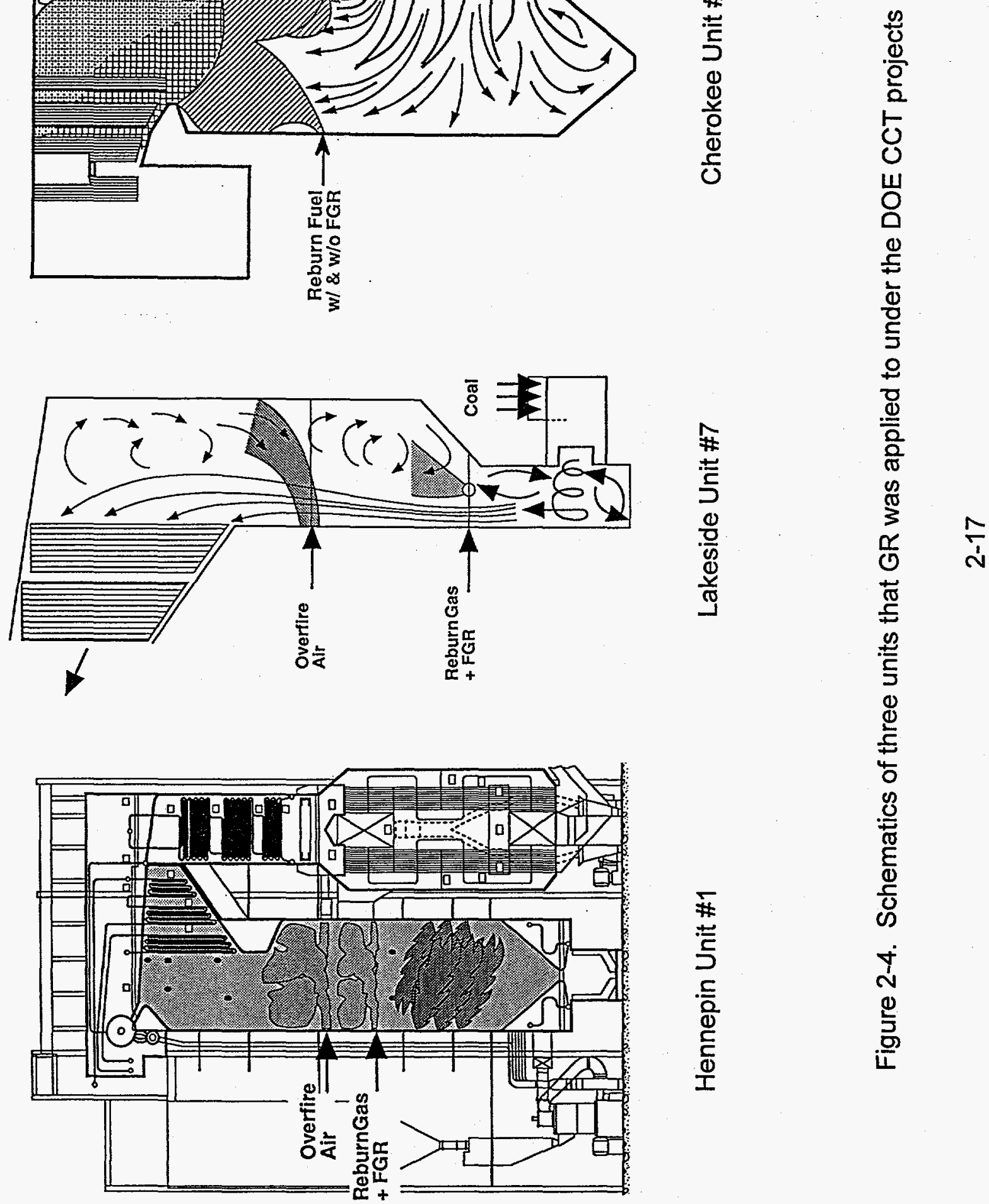


\section{Lakeside Station Unit \#7}

City Water, Light and Power's Lakeside Station is located in Springfield Illinois. Unit 7 is a cyclone-fired unit with a capacity of $33 \mathrm{MW}_{\mathrm{e}}$. The boiler is equipped with two cyclone burners which discharge into a secondary furnace. As with the Hennepin unit, EER designed an integrated GR-SI system for the Lakeside unit, although the reburning system could be operated with or without the SI system in operation. This application was the most challenging of the three and illustrates the potential to configure gas reburning to complex situations. The two counter-rotating cyclones discharge into a refractory lined well. Within the well, the combustion products transition into a jet moving up the rear wall. This high velocity region and the divergence of the furnace walls produce a large recirculation zone extending across most of the furnace. As a result, the available residence time in the reburning zone was limited to 0.25 seconds.

The gas and FGR injectors were located along the rear wall and side walls at the top of the refractory well. Although the penetration distance was short, fast mixing was required due to the limited reburning zone residence time. Overfire air was injected from the rear wall in the upper furnace. This also posed a challenge since any overfire air which penetrated through to the recirculation zone could be transported down to the reburning zone.

\section{Cherokee Station Unit \#3}

A GR system was retrofitted to Unit \#3 of Public Service Company of Colorado's Cherokee Station. Unit \#3 is front wall fired with 16 burners and has a gross capacity of $172 \mathrm{MW}_{\mathrm{e}}$. The retrofit involved integration of Foster Wheeler low $\mathrm{NO}_{x}$ burners with the GR system. The GR system was designed using the baseline $\mathrm{NO}_{x}$ performance of the unit and the projected $\mathrm{NO}_{\mathrm{x}}$ reduction performance of the Foster Wheeler burners. In the First Generation GR system that was installed and tested, the reburning fuel was injected with the FGR through ports on the front and rear furnace walls above the top burner row. In the Second Generation system that was later installed and tested, the FGR was eliminated. Overfire air was injected through ports on the front wall only just below the nose. This configuration provided a reburning zone residence time of 0.5 seconds. 


\section{Thermal Performance}

The use of GR is expected to have some impact on boiler performance. The addition of the reburning fuel to the furnace above the primary heat release zone effectively shifts a portion of the heat absorption into the upper furnace. In addition, the use of air or flue gas as a carrier for the reburning fuel can also impact the distribution of heat absorption between the furnace and the convective pass. Boiler efficiency can also be influenced by changes in the hydrogen/carbon ratio of the reburning fuel and in carbon in ash.

Thermal performance models were used to evaluate the potential effects of reburning on the operation of each of the three demonstration boilers. The predicted impact of gas reburning on the mean gas temperature profile and heat absorption distribution for the Cherokee boiler are shown in Figures 2-5. The model predictions compared well to field data. It is also seen that the overall impact of gas reburning on the furnace thermal profile is minimal. The results shown indicate that the heat absorption pattern is modified such that more heat is absorbed in the reheater and superheater sections and less heat is absorbed in the radiant furnace. These impacts do not strongly influence boiler operation as long as sufficient attemperation capacity exists, as it did at each of the three demonstration sites.

The overall impacts of reburning on unit performance was found to be moderate and well within the control capabilities of each of the boilers. Due to the use of natural gas as a reburning fuel, a slight reduction in boiler efficiency was experienced. During long term testing on each of the units, the reductions in boiler efficiency ranged from 0.5 to 1.7 percent.

\section{$\mathrm{NO}_{x}$ Control Performance}

Prior to retrofitting reburning to each of the boilers, the emissions control performance was estimate using a kinetic model of the reburning process. For the Hennepin unit a $\mathrm{NO}_{\mathbf{x}}$ reduction of 62 percent was projected. For the Lakeside boiler with the shorter reburning zone residence time the $\mathrm{NO}_{x}$ control performance was projected at 60 percent reduction 


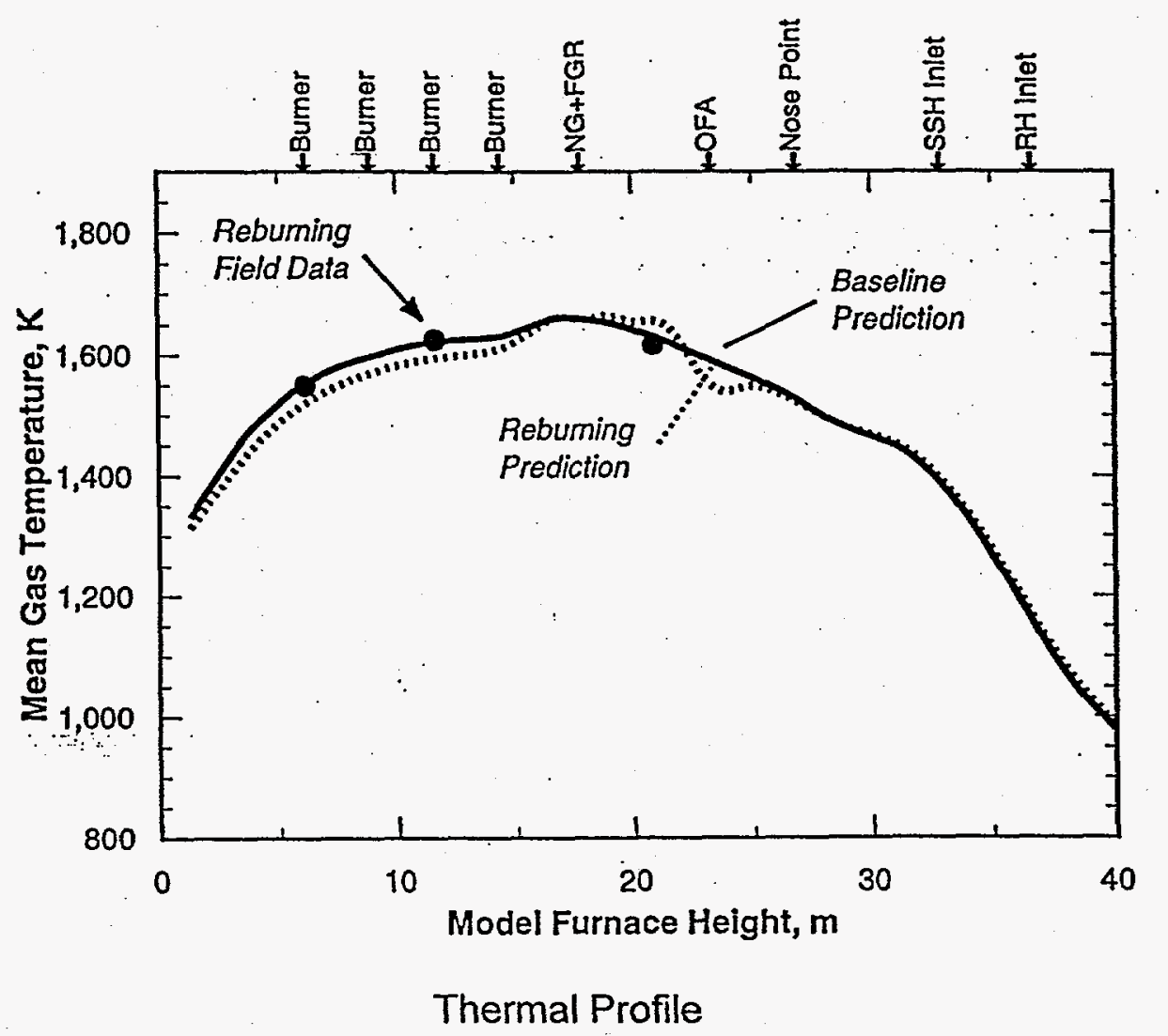

Model Predictions

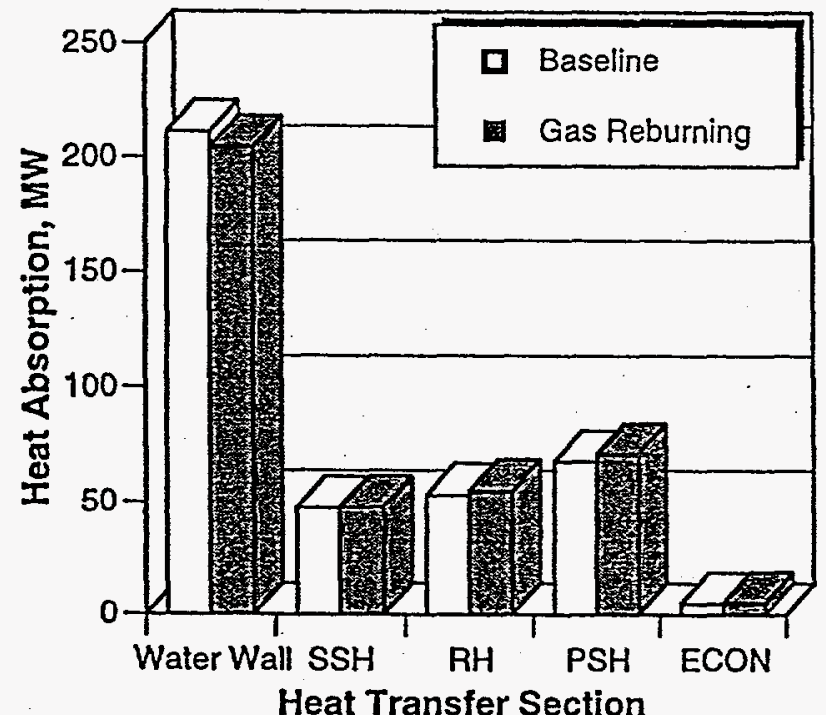

Field Data

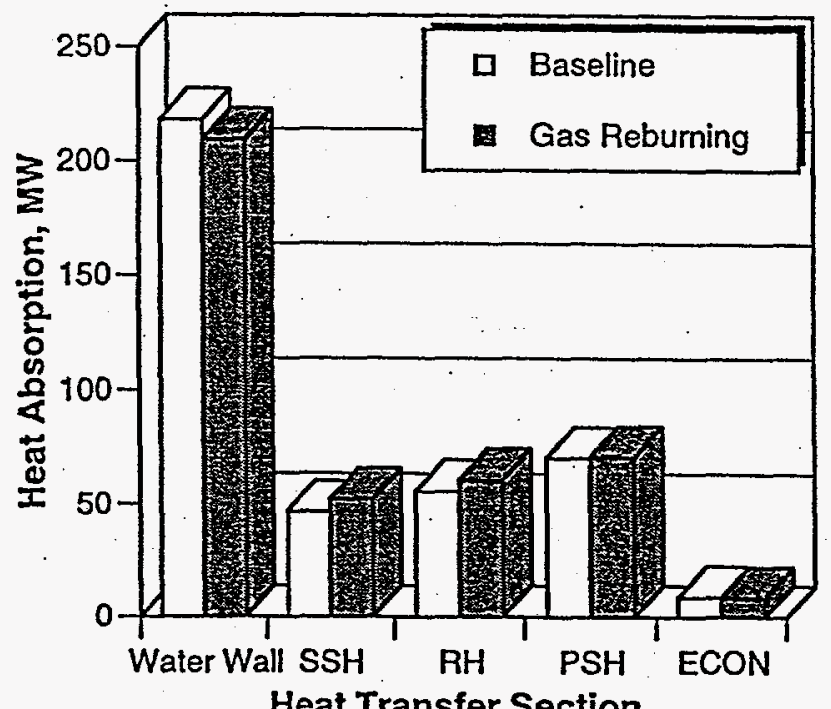

Heat Transfer Section

Heat Absorption Distribution

Figure 2-5. Impacts of GR on Cherokee Unit \#3 thermal profile and heat absorption 
even though the initial $\mathrm{NO}_{x}$ levelwas higher than that of the Hennepin unit. At Cherokee, $\mathrm{NO}_{\mathrm{x}}$ emissions were expected to be controllable to $70 \%$ when reburning was used in conjunction with low $\mathrm{NO}_{x}$ burners.

Hennepin Unit \#1 Prior to the retrofit, $\mathrm{NO}_{\mathrm{x}}$ emissions from the Hennepin unit were 0.75 $\mathrm{lb} / 10^{6} \mathrm{Btu}$. Following startup and optimization of the reburning system, the plant personnel operated the GR system following the normal load dispatch which involved a significant level of cycling. Figure 2-6 shows the measured field $\mathrm{NO}_{x}$ emissions compared to the predicted level of $\mathrm{NO}_{x}$ reduction (62\%). The average measured $\mathrm{NO}_{x}$ emission level, over long term testing, was $0.245 \mathrm{lb} / 10^{6} \mathrm{Btu}$, a $67 \%$ reduction from baseline.

Lakeside Unit \#7 Since this is a cyclone-fired unit that has a hotter barrel/furnace, baseline $\mathrm{NO}_{x}$ emissions were higher than that of the Hennepin Unit $\left(0.95 \mathrm{lb} / 10^{6} \mathrm{Btu}\right)$. Even so, this unit was small ( $33 \mathrm{MW}_{\mathrm{e}}$ ) and had a lower baseline $\mathrm{NO}_{\mathrm{x}}$ than larger (hotter) cyclone units which can range up to $2.0 \mathrm{lb} \mathrm{NO} / 10^{6} \mathrm{Btu}$. As at Hennepin, GR was operated by the plant in normal commercial service following optimization tests. This boiler is typically operated as a peaking unit during winter and summer months.

Figure 2-7 shows the predicted $\mathrm{NO}_{x}$ emissions based on reburn zone stoichiometric ratios showing baseline and GR field data and EER prediction curves. The prediction band represents the impacts of the distribution of time-temperature histories experience by the reburning fuel in the complex flow fields illustrated in Figure 2-4.

Two sets of model predictions are compared: one set in which the effects of entrainment of overfire air into the reburning zone is taken into account, and one in which this phenomenon is neglected. Relatively good agreement between the model predictions and the field data have been obtained using this modeling technique. The good agreement between the model predictions and the measured results indicates that all major parameters which influence reburning performance are correctly accounted for in the model. 


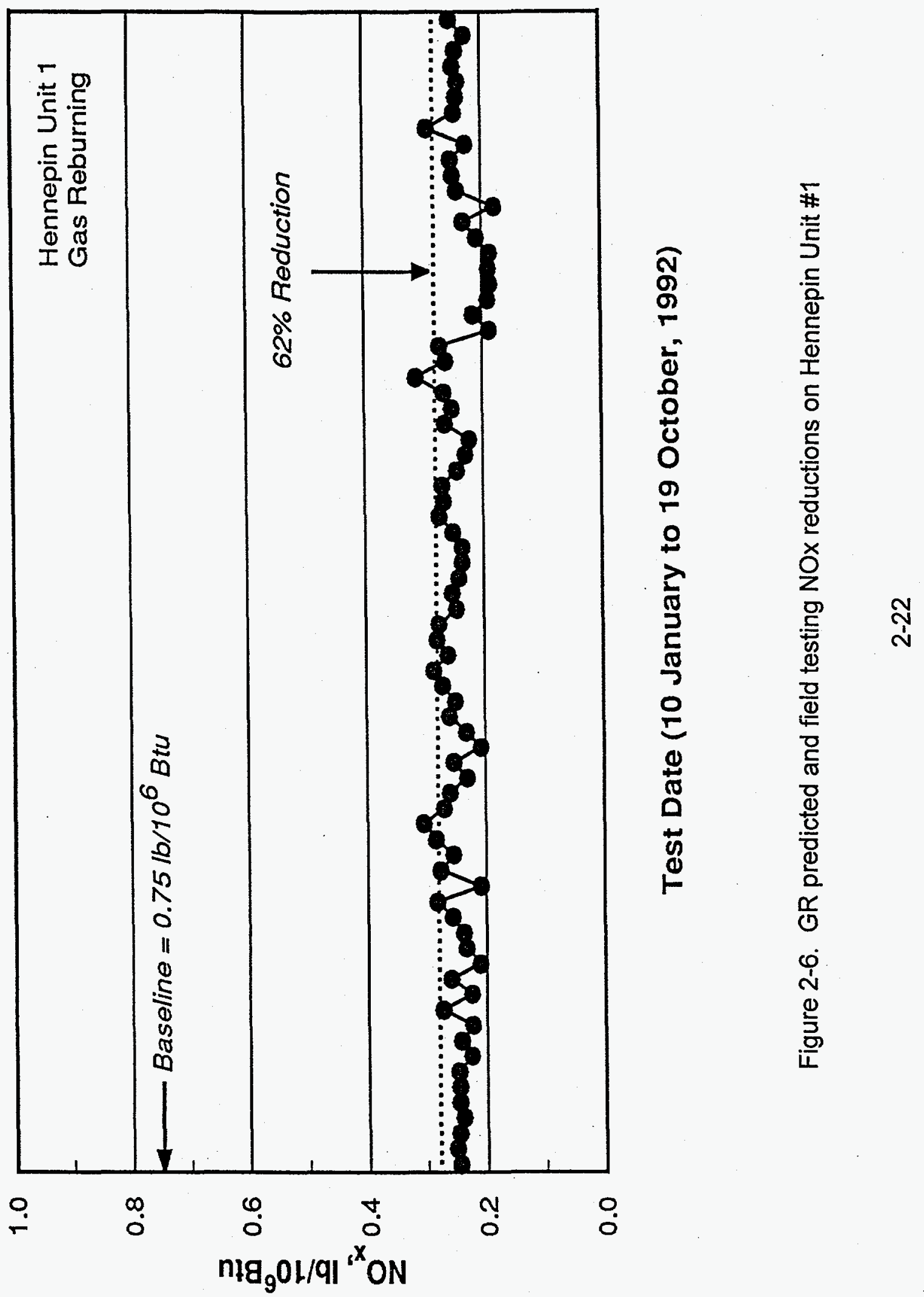




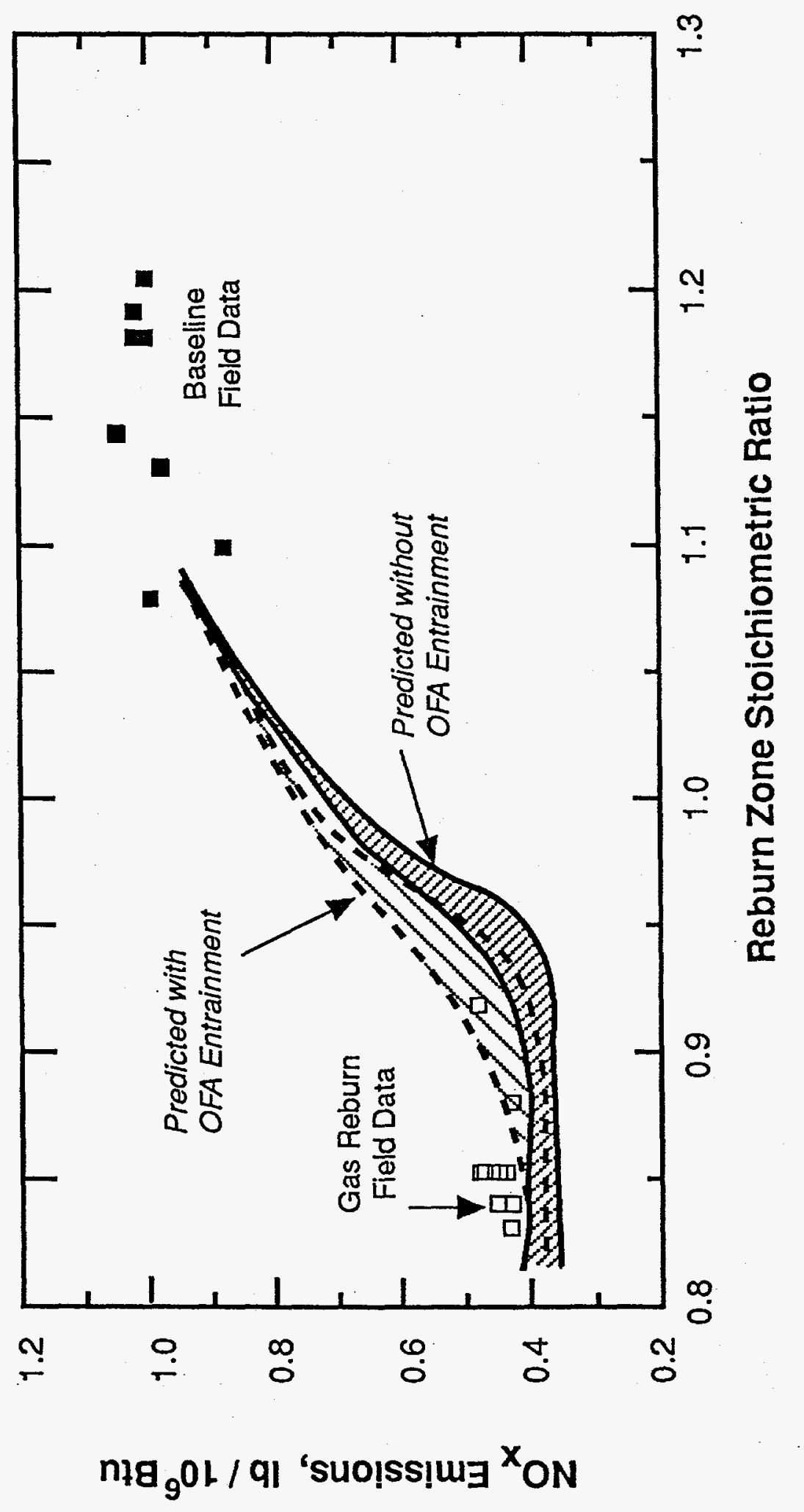

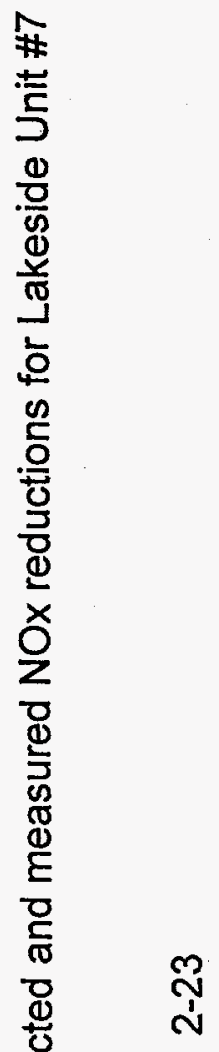


Figure $2-8$ shows the predicted-(60\% reduction) versus field $\mathrm{NO}_{x}$ reductions for the long term test on this unit. The average field data emissions were $0.344 \mathrm{lb} \mathrm{NO} / 10^{6} \mathrm{Btu}$, a $66 \%$ reduction from baseline.

Cherokee Unit \#3 $\mathrm{NO}_{x}$ emissions from the Cherokee boiler were $0.73 \mathrm{lb} / 10^{6}$ Btu prior to the retrofit of any equipment, and were reduced to $0.48 \mathrm{lb} / 10^{6} \mathrm{Btu}$ by the initial design of the low $\mathrm{NO}_{x}$ burners. Figure 2-9 shows the $\mathrm{NO}_{x}$ emissions measured during the long term tests where the unit was operated under normal dispatch conditions. For this period, the average emissions were $0.26 \mathrm{lb} / 10^{6} \mathrm{Btu}$, a $64 \%$ reduction from baseline. The level of NOx emission reduction was lower than that projected $(70 \%)$ for the combined use of GR-LNB due to the lower than expected levels of control provided by the low $\mathrm{NO}_{x}$ burners.

Following the initial tests of the Cherokee unit, the gas reburning system was modified to eliminate flue gas recirculation to the nozzles to boost the reburning fuel momentum. The modified nozzles used high velocity gas injection to provide the energy necessary for reburning fuel mixing. In addition to this modification, the overfire air ports were modified to provide improved carbon monoxide control at low reburning fuel flow rates, and the low $\mathrm{NO}_{x}$ burners were modified to improve carbon in ash. Figure 2-10 compares the $\mathrm{NO}_{x}$ emissions from the initial and modified systems. The results are similar, with the modified systems performing slightly better at higher reburning zone stoichiometric ratios (less reburn gas).

Field Results Comparison Figure 2-11 compares the field data of $\mathrm{NO}_{x}$ emissions for the three GR installations as a function of reburn gas heat input. The variation in the baseline data for the installations are the result of varying excess air levels (i.e., the higher the $\mathrm{O}_{2}$ concentration in the flue gas, the higher the $\mathrm{NO}_{x}$ emissions). For all three installations, $\mathrm{NO}_{x}$ decreases as the reburn gas heat input increases. For the tangential and wall-fired units, the slope of the curve is relatively flat over the reburn fuel heat input range of 10 to $20 \%$, while for the cyclone unit (with shorter reburning zone residence time), $\mathrm{NO}_{\mathrm{x}}$ declines significantly by increasing the reburn gas heat input from 10 to $20 \%$. 


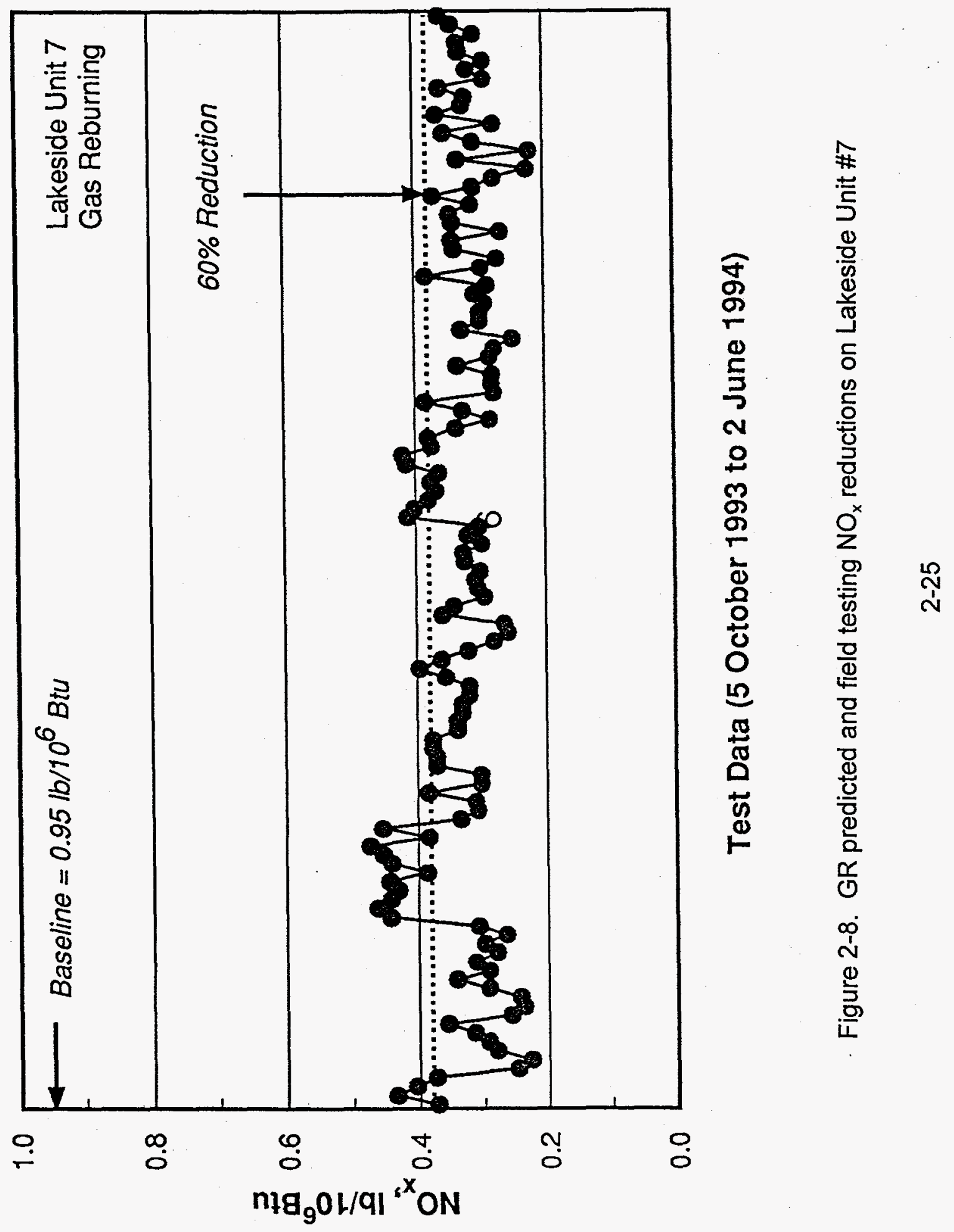




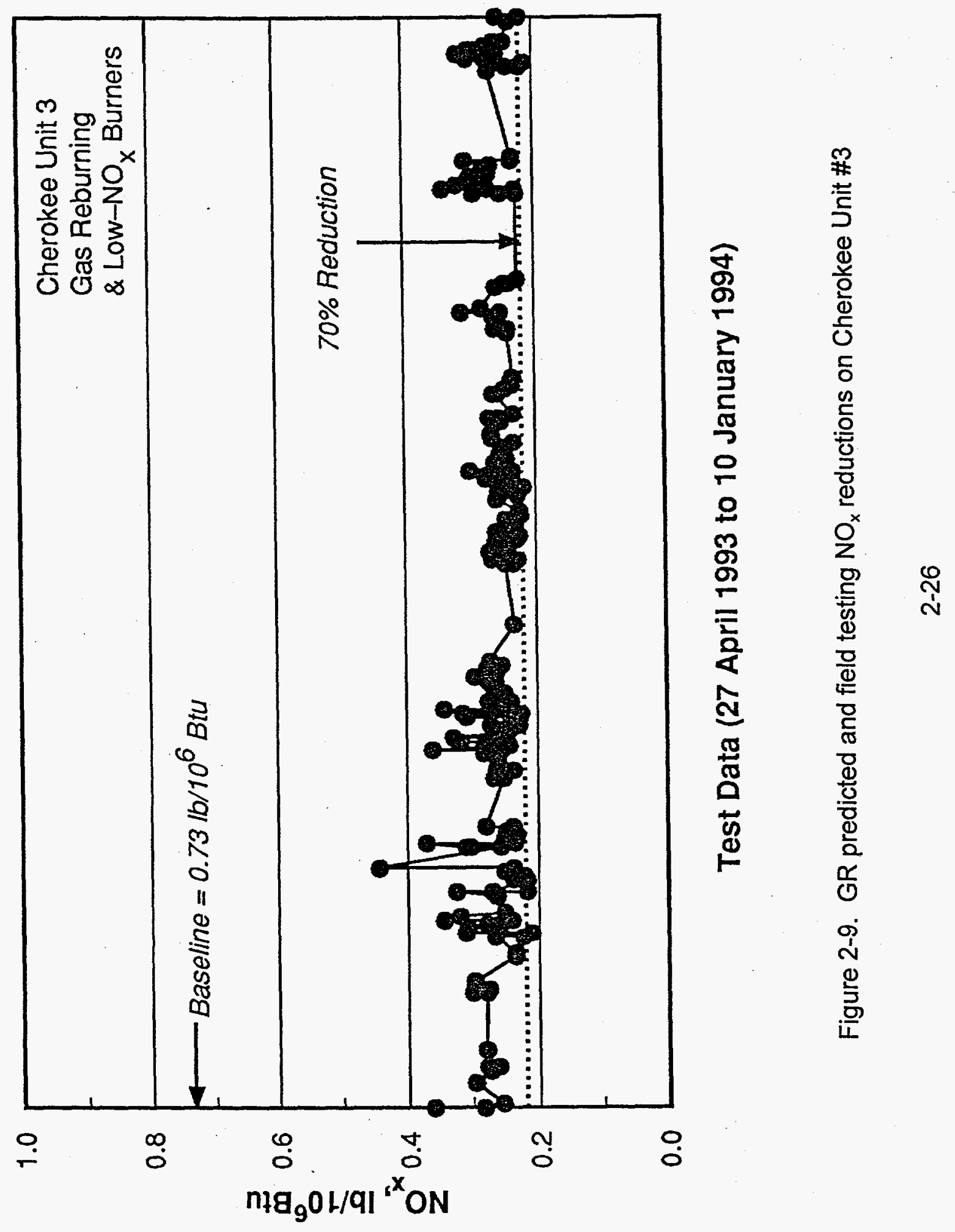




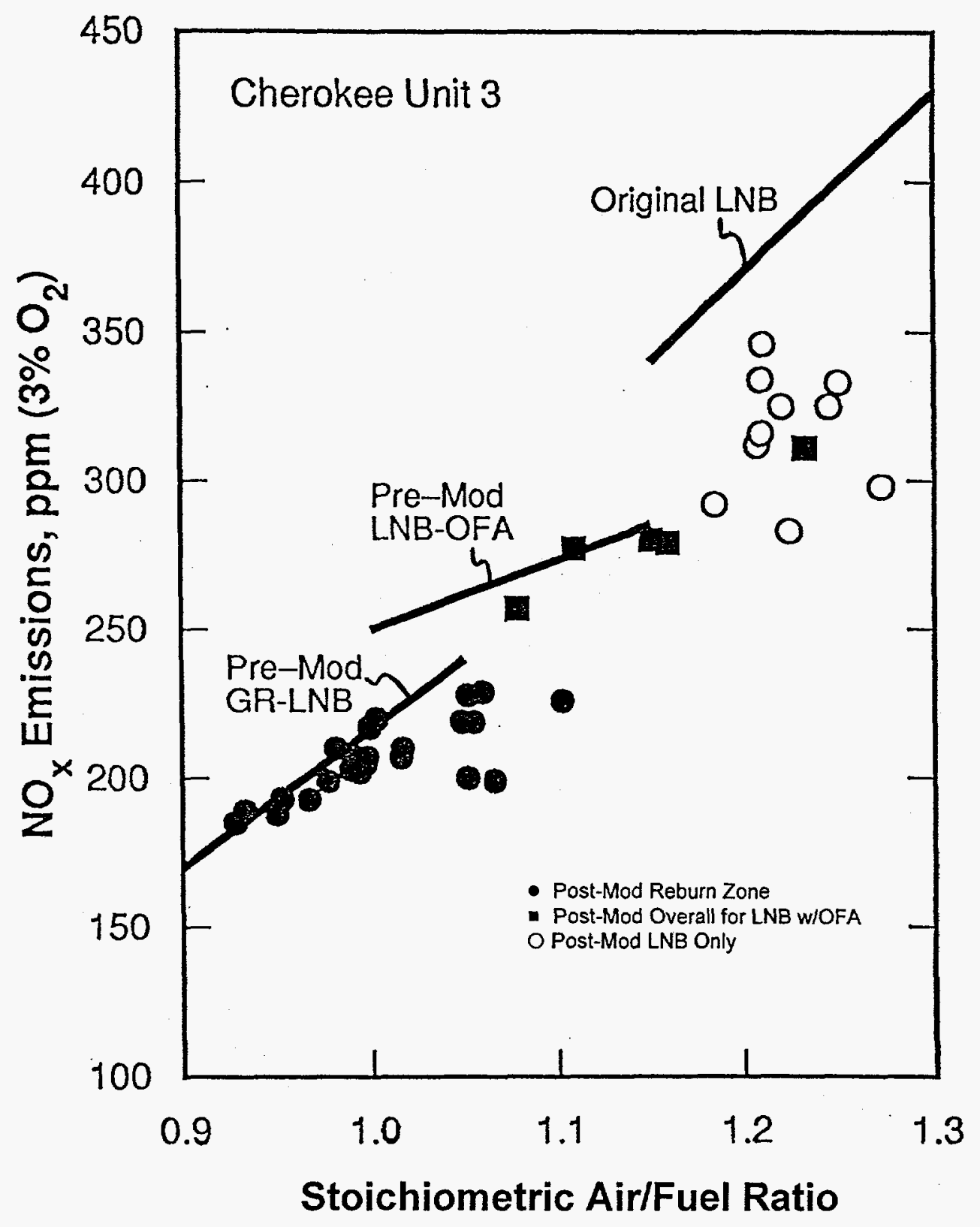

Figure 2-10. $\mathrm{NO}_{x}$ reduction performances of Cherokee GR-LNB Modifications 


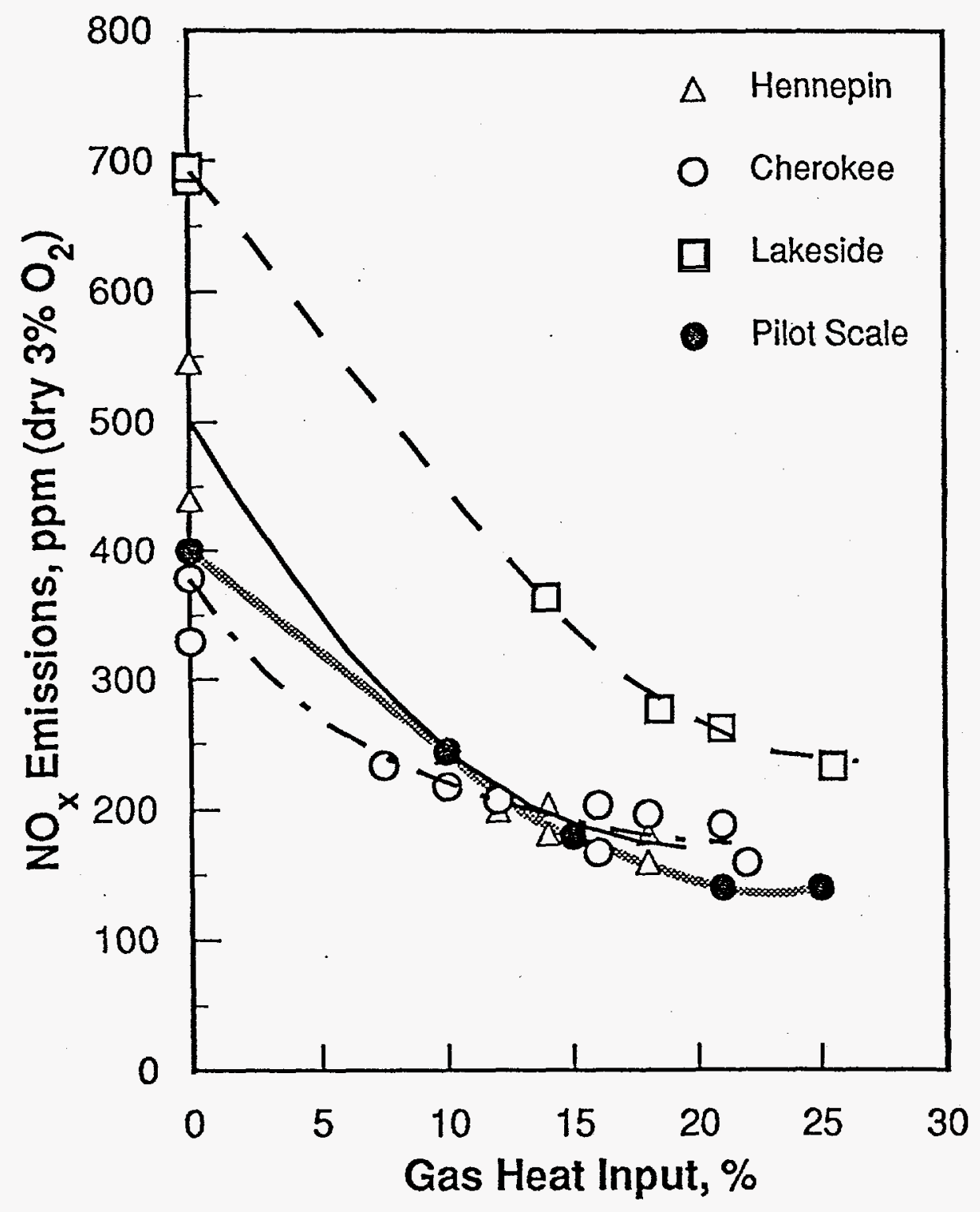

Figure 2-11. $\mathrm{NO}_{\mathrm{x}}$ reduction performances of pilot unit and three $\mathrm{GR}$ demonstrations 


\section{Conclusions}

A design methodology has been developed that permits reburning to be applied to boilers of different sizes and firing configurations, including tangentially, wall- and cyclone-fired boilers. The methodology has been used to successfully design reburning systems for three utility boilers covering the range of 33 to $172 \mathrm{MW}_{\mathrm{e}}$. The impacts of reburning on boiler performance and emissions have been predictable to a large extent. The overall impacts of reburning on unit performance have been found to be moderate, and well within the control capabilities of each of the boilers. No significant operational or durability problems were encountered. $\mathrm{NO}_{\mathrm{x}}$ reductions exceeded 60 percent at each of the sites.

The results of these three field evaluations have validated EER's design methodology. Based on these successes, EER has completed a GR system installation on a $108 \mathrm{MW}_{\mathrm{e}}$ tangentially fired unit (New York State Electric \& Gas). In addition, EER has completed a a reburning system using micronized coal as the reburn fuel. This micronized coal reburn system was installed on a $50 \mathrm{MW}_{\mathrm{e}}$ cyclone-fired unit (Kodak). EER is currently starting up a GR system that was applied to a Tennessee Valley Authority cyclone-fired unit and are working on the designs for two cyclone-fired unit applications for Baltimore Gas \& Electric.

\subsection{Low NO${ }_{x}$ Burners}

LNBs reduce $\mathrm{NO}_{x}$ emissions by staged combustion. This is accomplished through the mixing of coal and air producing a fuel-rich region within the flame zone and also producing longer flames to lower the peak flame temperatures. These burners generally use dual concentric secondary/tertiary air registers to accomplish this. Different air swirl patterns are applied to these two zones to create the reducing zone and longer flames.

LNB retrofits may involve increasing the burner throat. Larger burner throat diameters generally favor a more gradual coal/air mixing that translates to lower $\mathrm{NO}_{x}$ emissions. If the throat is increased certain furnace tubes will have to be removed and new bent tubes 
installed. If the burner throat diameter is adequate to achieve the desired $\mathrm{NO}_{\mathrm{x}}$ reduction then only minor modifications, such as a change in refractory, may be required. Conventional burners (not low $\mathrm{NO}_{x}$ designs) may also be modified rather than replaced to provide for lower $\mathrm{NO}_{x}$ emissions. While $\mathrm{LNBs}$ reduce $\mathrm{NO}_{x}$, they can also yield higher levels of unburned carbon-in-ash and higher emissions of $\mathrm{CO}$ than conventional burners. Foster Wheeler Energy Corporation's Controlled Flow/Split Flame low $\mathrm{NO}_{x}$ burners were installed and tested on Cherokee Unit \#3. 


\subsection{ENGINEERING DESIGN}

The GR-LNB system is designed to reduce $\mathrm{NO}_{\mathrm{x}}$ emissions by $70 \%$. Further, it is to be designed in such a way as to minimize potentially harmful impacts, such as furnace wall corrosion and superheater tubewall erosion. The gas reburning and low $\mathrm{NO}_{x}$ burner technologies, although there are synergies in operation, are totally independent $\mathrm{NO}_{x}$ control technologies, i.e., one can be applied without the other. For this reason the engineering designs are discussed separately.

\subsection{Gas Reburning System}

The First Generation GR system is comprised of three subsystems: natural gas injection, FGR injection, and OFA injection. These subsystems are integrated to provide the proper fuel, FGR and air flows into the appropriate regions of the furnace to reduce $\mathrm{NO}_{x}$ and to supply the heat needed for steam generation at the units rated capacity. In the Second Generation GR system, FGR is eliminated. It is comprised of only two subsystems: natural gas injection and OFA injection. These subsystems are integrated to provide the proper fuel and air flows into the appropriate regions of the furnace to reduce $\mathrm{NO}_{\mathrm{x}}$ and to supply the heat needed for steam generation at the unit's rated capacity.

\subsubsection{Natural Gas System}

For full scale electric utility GR applications, whether First or Second Generation GR technology is used, approximately 15 to 25 percent of the total heat input to the furnace is supplied by natural gas for the reburning process. Based on this gas heat input, one can roughly size the volumetric rate $(\mathrm{scfm})$ requirements for the natural gas to be supplied to the furnace. Standard piping design practices in conjunction with the rate requirements are used to size supply and distribution piping from existing headers within the facility and also, in some applications, pipelines off site. 
Gas line pressures are designed to accommodate the volumetric requirements while maintaining reasonable pipe sizes. Normal pressures are 100 psig in headers, 20 psig at the control valve trains, and $1-4$ psig at the injection nozzles.

Studies conducted by EER determined the effect of penetration and mixing in the reburn zone. It was found that the natural gas had to be injected in such a way so that it would cover the cross-sectional area normal to flue gas flow in order for the reburn process to be most effective. Also, if the injection momentum of the natural gas was not sufficient, the injected fuel would simply follow a flow path adjacent to the boiler wall where it was injected. On GR installations with FGR as the inert to assist penetration and mixing of the natural gas with the furnace gases, the natural gas pressure supplied to the injection nozzles ( 15 to 20 " W.C.) is slightly higher than the pressure of the flue gas at the nozzle. In the Second Generation GR process where FGR is eliminated, higher gas pressures ( $\sim 30$ to $40 \mathrm{psig}$ ) are delivered to the gas injection nozzles to provide the necessary momentum to adequately penetrate the furnace flue gases and provide for good mixing.

To survive the high temperatures of the furnace environment, both water-cooled metal and high temperature ceramic GR injection nozzle designs have been used. Nozzle provisions when using FGR should also be made to resist erosion from fly ash. Cooling fans are required to provide cooling air to the injection nozzles during non-operation of the GR system and to provide seal air for positive pressure units.

Control of natural gas flow into the furnace is critical not only for optimizing the GR process, but for maintaining boiler firing control and safety. GR itself is a chemical process that is different from combustion, but natural gas flow into the boiler is treated as another fuel input. Specific equipment and design recommendations with regard to gas firing are available in the National Fire Protection Association (NFPA) Standards 85B, "Prevention of Furnace Explosions in Natural Gas-Fired Multiple Burner Boiler-Furnaces", and 85C, "Prevention of Furnace Explosions/Implosions in Multiple Burner Boiler-Furnaces". 


\subsubsection{Flue Gas Recirculation System}

The mass flow rate of natural gas injected into the reburning zone does not always have sufficient momentum to penetrate into the furnace flue gases for adequate mixing. As such, an inert gas may be added to the smaller rate of natural gas before injection into the furnace via several high velocity jets. The combination of the higher velocity with a higher mass flow will then provide the necessary momentum for good in-furnace mixing.

The logical source of the inert gas is the combustion flue gas at the boiler exit. At this location in the process, oxygen levels in the flue gas are at their lowest since air heater leakage downstream may significantly increase the oxygen concentration of the flue gas. The temperature of the flue gas extracted at this location eliminates the need for preheating the gas. Note that injection of low temperature gas streams into the furnace may quench the reburning process and contribute to ash and slag formations known as "eyebrows" at the openings.

Selection of the GR nozzle configuration (size, jet velocity, number, and location) is based on furnace gas flow modeling with prime consideration being given to penetration and mixing with the furnace combustion gases. As with any of the process streams, FGR flow must be metered to control the reburn process. A venturi is the preferred metering device since it can accommodate the ash loading and high temperatures $\left(600^{\circ} \mathrm{F}\right)$. A clean air purge assembly is attached that prevents fly ash obstructions in the pressure sensing lines.

\subsubsection{Overfire Air (OFA) System}

OFA is injected into the boiler to complete combustion of the reburn fuel. OFA is typically 15-20 percent of the total air flow. When applying reburning, it is desirable to minimize the overall excess air level to maintain high thermal efficiencies. However, the OFA must also be adjusted to minimize CO emissions. The OFA flow capacity is bound by (1) the 
minimum air requirements to consume the remaining combustibles and (2) the maximum air available from the windbox.

The penetration and mixing of the OFA has to cover the entire cross-sectional area of the furnace perpendicular to the upward flowing furnace gas to achieve acceptable CO emission levels leaving the OFA or burnout zone. Each furnace of varying size will have a certain required minimum OFA pressure to provide the penetration and mixing desired. The injection angle may be pointed downward in some cases to provide for a longer time for penetration and mixing of the OFA into the upward flowing furnace gas. The OFA ports are normally cooled with an air supply from a small fan.

\subsection{Low NO $\times$ Burners}

There are many low $\mathrm{NO}_{x}$ burner manufacturers in the world and EER is one of them. Since EER does not have formal design information on its competitors' low $\mathrm{NO}_{x}$ burners, the burners discussed here are the EER FlamemastEER ${ }^{\mathrm{TM}}$ low $\mathrm{NO}_{\mathrm{x}}$ burners only. In 1987, EER participated in a joint development program with Elkraft Power, a Danish utility, and Burmeister \& Wain Energi (BWE), a Danish boiler and combustion system manufacturer, to develop a reliable, high quality, high performance low $\mathrm{NO}_{\mathrm{x}}$ burner capable of reducing $\mathrm{NO}_{x}$ emissions by $50 \%$. The burner developed is shown in Figure 3-1. These low $\mathrm{NO}_{\mathrm{x}}$ burners have been installed in both Europe and North America. The burner has similar components and yields similar $\mathrm{NO}_{\mathrm{x}}$ performance results compared to other commercial low $\mathrm{NO}_{\mathrm{x}}$ burners. The mechanical construction of the burner is unique and has several advantages over other low $\mathrm{NO}_{x}$ burners. The key features of the design include:

- Variable combustion air supply through separate secondary and tertiary passages

- Variable swirl on both the tertiary and secondary air

- Flameholder attached to the coal nozzle 


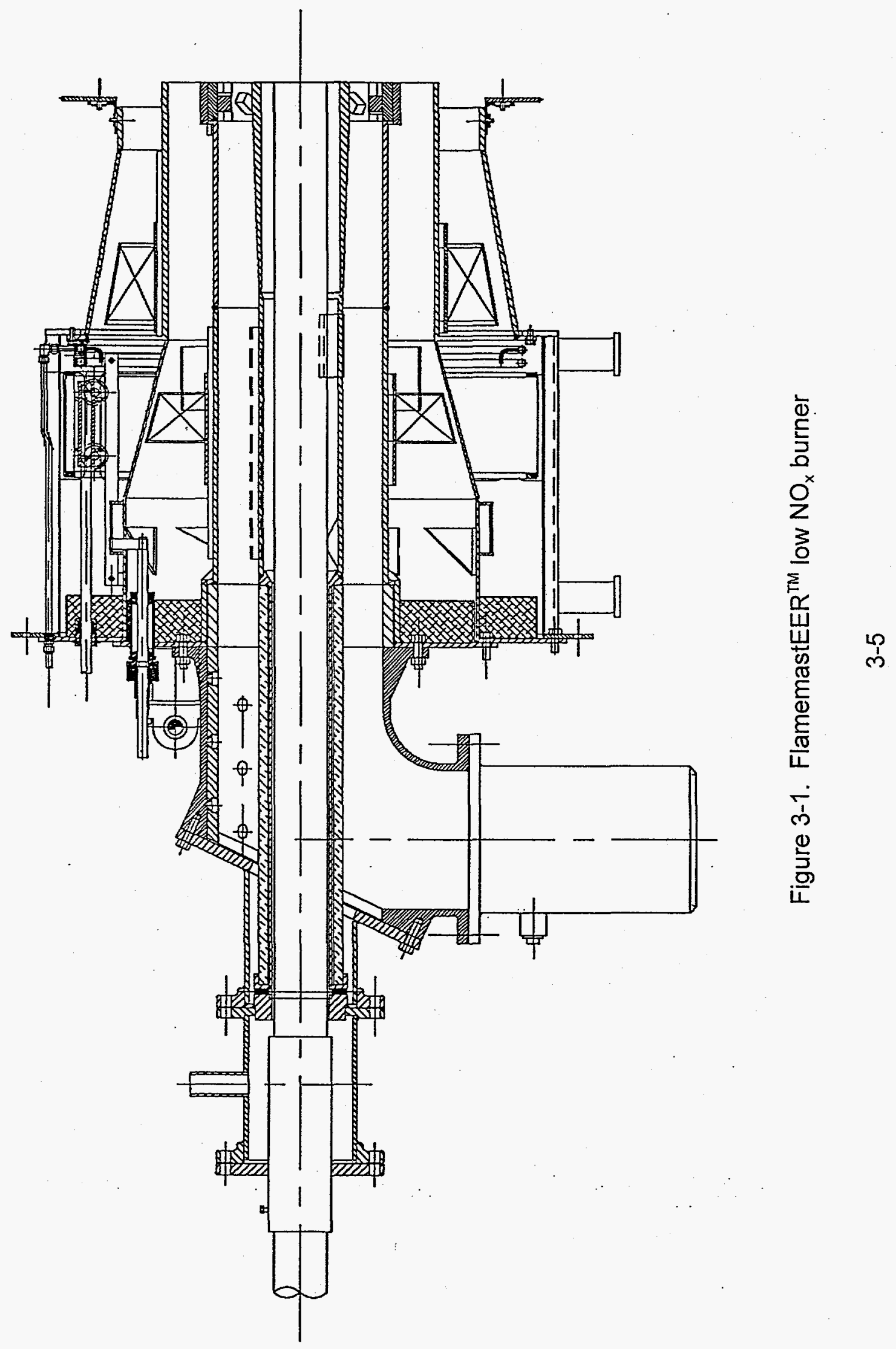


Mechanically, the burner has been designed to minimize the number of moving parts. Those parts which do move slide axially, eliminating complex linkages and gears. The secondary and tertiary swirl control vanes, called turbolators, move back and forth within conical passages of the burner. As the turbolators are moved toward the narrow end of the cone more air passes through the vanes, increasing the amount of swirl. As the turbolator is moved in the opposite direction, the air follows the path of least resistance and by-passes the vanes, resulting in less swirl. The amount of combustion air entering each burner is controlled by a sliding ring damper. Similarly, the split between secondary and tertiary (outer zone) air is controlled by a second ring damper. The parts of the burner which are subjected to a high heat flux are fabricated from a high strength, heat resistant alloy.

By setting the air distribution between the secondary and tertiary zones and by moderating the tertiary air swirl the burner flame is lengthened across the firing depth. The longer, cooler flame in combination with reducing zones within the flames represents the main variables to reduce $\mathrm{NO}_{x}$ emissions. The low primary air/coal velocity and flameholder are designed to provide good flame stability and acceptable flame characteristics for a wide range of operating conditions and fuel characteristics. The flameholder establishes local recirculation zones and promotes local mixing between the coal and the secondary air. This leads to a rapid devolatilization of the coal and liberation of fuel nitrogen in a low excess air environment resulting in reduced $\mathrm{NO}_{\mathrm{x}}$ formation.

With deregulation of the electric utility Industry approaching, many utilities are looking for lower cost alternatives to reduce $\mathrm{NO}_{\mathrm{x}}$ emissions. Justifying new low $\mathrm{NO}_{x}$ burners on a boiler that is $30-40$ years old and has limited remaining life is difficult. EER has developed a technique to modify existing conventional burners to reduce $\mathrm{NO}_{x}$ emissions, and rather than buying new burners for a GR-LNB retrofit the burner modification approach provides the utility with a lower cost option. Modifications are usually 2 to 4 times less expensive than new low $\mathrm{NO}_{\mathrm{x}}$ burners. 
Units which are the best candidates for burner modifications include:

- Older units where the expense of new burners is difficult to justify over the remaining boiler life.

- Units operating under a system-wide $\mathrm{NO}_{x}$ averaging strategy, where compliance on all boilers is not essential, and where burner modification offers an economical option for smaller units.

- Units requiring greater than $55 \% \mathrm{NO}_{x}$ reduction, where burner modifications can provide an economical NO reduction. GR, SNCR, SCR, or other technologies may then be coupled with it to provide the deep $\mathrm{NO}_{x}$ reduction required.

- Units with first generation low $\mathrm{NO}_{x}$ burners where only moderate additional $\mathrm{NO}_{x}$ reduction is required.

- Units with conventional burners firing sub-bituminous or other highly reactive coals.

The modifications to be performed for each application will vary widely according to the type of burner, the $\mathrm{NO}_{x}$ reduction required, and site specific information such as coal, burner area heat release rate, etc. To perform an initial evaluation, specific site information is required. After completing preliminary calculations, based on site information, the next step is usually a windbox inspection of the existing burners. Some projects then require a reduced scale isothermal modeling study of the existing burner to determine the exact detailed modifications. Other projects that are similar to previous jobs or only require a small $\mathrm{NO}_{\mathrm{x}}$ reduction do not require modeling.

The goal of modeling is to determine the specific modifications required to simulate the burner mixing rates and exit aerodynamics of EER's commercial LNB. The hardware modifications are usually configured so that the existing burner does not have to be removed from the windbox, which is a major advantage when old boilers contain asbestos. 


\subsection{Furnace / Boiler - -}

\subsubsection{Bent Tube Openings}

Depending on results of the process design, application of the GR-LNB technology may require as many as thirty tube wall penetrations to be made in the furnace water walls to accommodate the GR injection nozzles and the furnace gas temperature monitoring equipment. Each water wall opening may require from four to eight bent tubes to be installed, possibly affecting over one hundred of the water wall tube circuits.

Further, for certain low $\mathrm{NO}_{\mathrm{x}}$ burner applications a larger burner throat diameter may be required which would also require the bending of more furnace wall tubes. In considering the application of GR-LNB, the impact of the bent tube openings on circulation and steam generation in the lower furnace water walls should be investigated.

\subsubsection{Combustion Air (Overfire Air Source)}

Air required for the OFA system is usually taken from the combustion air system. It has been preheated and may have a sufficient velocity head for injection through the OFA nozzles into the furnace gases. Process design information will provide the necessary OFA flow and velocity head requirements. The existing combustion air supply system is reviewed in terms of fan capacity and available velocity head. Available velocity head can be increased by closing dampers that supply air to the primary combustion zone. However, the capacity of the forced draft fan(s) may be limiting. If capacity is available but the velocity head is not sufficient, a booster fan will be required for the OFA supply. The LNBs are replacement burners and as such, the existing combustion air supply will normally require only minor modifications. 


\subsubsection{FGR Source}

FGR is used as an inert propellant for natural gas in the reburning process. Flue gas is drawn after the last heat transfer tube bank (economizer or boiler bank) so as to not affect steam temperatures, and prior to the air heater since leakage there increases the oxygen level of the FGR. The configuration of the duct work leading from the boiler outlet to the air heater inlet should be reviewed with respect to a location for the flue gas tap. The tap should be located such that access to the center of the flue gas duct is possible to minimize tramp air entry. Tramp air (from casing leaks on balance draft units) and seal or cooling air from burners or other furnace water wall penetrations enters the flue gas and follows the furnace and duct walls. The flue gas tap should also be located to allow placement of a multi clone dust collector as close to the gas source as possible. Since the gas is cleaned of particulate immediately after being extracted from the boiler exit, problems with ash accumulation and erosion in the FGR duct work are eliminated.

\subsubsection{Equipment Footprint}

Installation of GR-LNB systems will require the placement of equipment, duct work and piping in a boiler house that may already be space limited. Following is a list of major GRLNB equipment, duct work and piping for which space requirements should be considered in a GR-LNB retrofit:

\section{GR System}

- $\quad$ GR and OFA bent tubes for injection ports

- Natural gas metering, control, and shut-off valve station, and supply, distribution and vent piping

- $\quad$ FGR fan (if required), cooling fans, multi clone ash collector, flow measuring venturi, and interconnecting duct work

- OFA duct work and booster fan (if required) 


\section{$\underline{\text { LNB System }}$}

- $\quad$ May require larger burner throat diameter thus straight furnace wall tube sections may have to be replaced with bent tube sections

\section{Ancillary Equipment}

- New electrical power transformers and motor control centers

- $\quad$ Existing ductwork/piping modifications to accommodate the new GR piping and OFA ductwork

\subsection{Balance of Plant}

\subsubsection{Electrical Power Distribution}

GR-LNB equipment may be supplied power from the plant's auxiliary power system. However, the existing capacity of the electrical distribution and control system must be reviewed in light of the GR-LNB process needs. The primary electrical power consumers are cooling fan and OFA booster fan (if required) motors. Critical equipment such as cooling and booster fans, boiler controls, and turning gear should be supplied from motor control centers having redundant feeds to insure un-interruptible supply.

\subsubsection{Plant and Instrument Air}

GR-LNB system equipment, controls, and instrumentation will require dry instrument quality air for control valve operation, and also seal and cooling air. If the furnace is a positive pressure design, plant air will be required for the aspirated boiler waterwall penetrations. Existing plant and instrument air systems should be reviewed in terms of capacity and air quality (oil and water content) to determine if the needs of the proposed GR-LNB equipment can be met. 


\subsubsection{Controls}

Process control equipment and instrumentation installed as part of the GR-LNB system will undoubtedly be state-of-the-art digital equipment. A wide variety of boiler control equipment exists in use at utilities representing various generations of pneumatic, analog, and digital control equipment. Equipment installed on any one unit may be a mixture of these technologies, e.g., pneumatic, analog and digital field devices tied to microprocessorbased digital bench board equipment in the control room.

Consideration must be given to the control scheme for the new process equipment, especially in regard to interface capabilities relating to safety interlocks, firing control, and safety trips. If the interface capability is present, the utility may opt to add the new process equipment to the existing control equipment provided necessary input/output space is available or can be added, or add additional control equipment for GR-LNB operation which interfaces with the existing boiler controls. Particular attention must be paid to proper buffering and isolation of the two control systems so that the integrity and reliability of the existing boiler control system is maintained, but the transfer of data is also maintained between systems to ensure proper control strategy. Lacking the proper interface capability, an upgrade of the entire control room equipment may be warranted.

Since the GR process relies on setting precise stoichiometric ratios in the main burner, reburn, and burnout zones, above average combustion air control methods are required. Control systems that operate from an air-to-coal curve (lbs. of air per lb. of coal) do not lend themselves well to retrofit of the GR technology. This control method does not make adjustments for changes in coal heating value, moisture content, and air density, and actual stoichiometric ratios may differ from those desired. Since with GR, natural gas replaces a portion of the coal input to the unit, complicated control schemes are required on units operating under an air-to-fuel curve. The addition of boiler $\mathrm{O}_{2}$ trim into the air control scheme can overcome these awkward limitations and optimize the GR process. 
$\mathrm{O}_{2}$ trim is provided by in-situ flue-gas oxygen analyzers located at the boiler outlet. State of the art control systems allows $\mathrm{O}_{2}$ trim to be biased for the oxygen not participating in the combustion and burn-out processes which enters the flue gas via tramp air sources (wall box seal air or casing leakage). 


\subsection{SYSTEM OPERATION -}

\subsection{Control System}

Control and monitoring of the GR-LNB system is not complicated and may be accomplished with any modern control system that can be integrated into an existing boiler control system. The design of the GR-LNB control system is based on the following criteria:

- All normal operations that are required to start, stop, or modulate the various pieces of equipment shall be performed in the control room.

- Sufficient information shall be displayed in the control room to enable the operator to determine the status of all equipment. The operator interface shall be designed so that the above information is displayed in a manner to enable rapid understanding of system status.

- Certain operations shall be interlocked to prevent inadvertent operation of equipment when such operation may present an operating hazard or other undesirable condition.

- $\quad$ Certain shutdown procedures shall be initiated automatically by the control system when such operations are deemed necessary for safety or good operating practice.

- Microprocessor based technology shall be used for the controls and interlocks.

- Operator interface shall be of the keyboard-CRT type with custom graphics.

- The system will readily interface with existing plant instrumentation and be of a design that will enable operator familiarity and understanding with a minimum of training.

Interlocks are included which are designed to start the equipment in an orderly fashion and prevent the operator from allowing the unit's safety to become compromised either through erroneous operation or due to equipment failure. All major commands issued by the 
control system are verified by a feedback signal. Trip signals are continuously monitored and will prevent startup or shutdown of equipment already in operation.

\subsection{Operation}

\subsubsection{GR System}

The First Generation GR system is composed of three integrated systems: (1) natural gas injection, (2) FGR, and (3) OFA injection. The natural gas flow rate is controlled to the desired value for optimum $\mathrm{NO}_{x}$ destruction. The FGR flow is controlled at a rate that provides adequate natural gas momentum for optimum mixing in the furnace. The OFA is controlled to a rate to complete combustion of all unburned fuel leaving the reburning zone. The three integrated systems are interlocked, operated and monitored by the control system. With the Second Generation GR system the FGR is eliminated but the gas injection and OFA control remain the same.

The control logic for natural gas injection consists of a flow controller which receives a calculated set point from the boiler master and the natural gas flow transmitter. A comparison is made in the fuel controller between the set point and feedback signals and the controller output modulates the natural gas control valve to reduce any error to zero. The boiler master controls gas flow with coal flow to obtain the Btu input needed over the load range. A percentage of the boiler master signal is calculated and becomes the set point for the desired natural gas flow.

The desired FGR (when applied) flow control set point is a calculated value determined from the boiler master signal. This set point signal is compared with the actual value of FGR flow rate in a PID controller which acts upon any detected error signal. The control system will automatically adjust the FGR fan to reduce the error to zero. 
Control of the OFA system consists of sending a set point signal calculated from the boiler master signal to a controller where it is compared with the total of the OFA air flows. The OFA nozzles are modulated to reduce any detected difference in the set point and total OFA flow to zero. The control system compares the signals from the OFA flow transmitters to balance the flow of air.

Another control feature of the GR system is the cross limit between the OFA flow and natural gas flow. The set point for natural gas is compared with the OFA flow. If the natural gas flow set point is greater than the amount of OFA flow required for complete combustion of natural gas, the control system will decrease the natural gas set point to a value that permits complete combustion of the natural gas by the OFA. If the natural gas flow is greater than the OFA flow, the set point signal for OFA is increased to a value that will permit complete combustion of the natural gas. The above sequence is called cross limiting between the fuel (natural gas) and OFA and is very similar to the cross limiting features in the main combustion control between the coal feed and secondary air flow.

There is another cross limit between the FGR flow and the natural gas flow. If the FGR flow falls below a value that insures optimum penetration of the natural gas into the boiler (i.e., good mixing with the products of the coal combustion process), the set point for natural gas flow will be reduced to a safe value.

\subsubsection{LNB System}

The low $\mathrm{NO}_{\mathrm{x}}$ burners are operated as an independent system to $\mathrm{GR}$ with the exception of the permissive regarding the flame scanners. A select number of burner flame scanners must see a flame before the GR system may be put in service. The opposite is true also; if there are not enough burners sensing a flame the GR system will automatically shut down. 
The burners are controlled from the boiler master control system. The main secondary air flow dampers to each burner row are controlled by load demand. With the FlamemastEER ${ }^{\mathrm{TM}}$ burners, the air swirl settings for the secondary and tertiary air are normally set manually during initial startup and then the main damper to each row of burners is controlled by the pulverizer coal rate set point. There is one other variable that is normally changed when GR is combined with LNBs and that is the excess air to the burners. The LNBs under GR operation will normally be run at about 10 per cent excess air compared to 15 to $20 \%$ excess air with LNBs only.

\subsection{Optimization}

\subsection{1 $\quad$ GR System}

Optimization of the GR system is performed using a series of parametric tests to characterize the independent reburning variables and associated responses of the system at various boiler loads. By using these data, the appropriate set points can be established for a range of $\mathrm{NO}_{x}$ emissions reductions. Prior to optimization, baseline tests are performed in order to establish both the pre- and post-installation boiler conditions without $\mathrm{GR}$ in operation. Five independent variables are involved in the parametric tests including:

- $\quad$ Boiler load -- A sufficient number of load conditions must be tested to develop the curve generators for the control system that enable automatic load-following.

- Percentage of total heat input proportioned to natural gas The coal flow is reduced in direct proportion to the natural gas injected into the reburning zone.

- $\quad$ Percentage of total flue gas used in FGR The FGR system (if required) is used to provide momentum to the injected natural gas for optimum mixing with the boiler flue gas. The level of FGR can directly impact the $\mathrm{NO}_{x}$ conversion capabilities of the system. It has a greater impact for those applications where there are short reburn zone residence times $(<0.5 \mathrm{sec}$.). 
- $\quad$ Percentage of total combustion air used at OFA OFA impacts the ability to burnout the combustibles in the reburn zone gas.

- $\quad$ Primary zone stoichiometric ratio $\left(\mathrm{SR}_{1}\right)$ A low $\mathrm{SR}_{1}$ is optimal for $\mathrm{NO}_{\mathrm{x}}$ reduction. However, the utility must establish the lower limit of $\mathrm{SR}_{1}$ that minimizes the potential for corrosion in the bottom of the boiler. Flame appearance must also be acceptable. For cyclone boilers, there will be little change in $\mathrm{SR}_{1}$ due to the operational fuel-to-air ratio constraints characteristic of cyclones. The optimum $\mathrm{SR}_{1}$ therefore will be in the range of 1.05 to 1.15 , depending on boiler type.

Dependent variables include:

- $\quad$ Reburning zone stoichiometric ratio $\left(\mathrm{SR}_{2}\right) \mathrm{SR}_{2}$ is directly proportional to the natural gas heat input for an established $S R_{1}$ condition. At a zero gas condition, $\mathrm{SR}_{2}$ is equal to $\mathrm{SR}_{1}$. As gas is introduced, $\mathrm{SR}_{2}$ decreases. The optimum level of $\mathrm{SR}_{2}$ is around 0.90 .

- Burnout zone stoichiometric ratio $\left(\mathrm{SR}_{3}\right)$ All combustion air not used in the primary zone becomes OFA. Depending on the excess air level selected by the utility, $\mathrm{SR}_{3}$ will be approximately 1.15 .

Stoichiometric ratios are calculated using boiler data collected during testing. The following additional data are used to measure boiler emissions and assess operating characteristics:

- $\quad$ Stack emissions These include $\mathrm{NO}_{\mathrm{x}}, \mathrm{O}_{2}, \mathrm{CO}$, and $\mathrm{CO}_{2}$.

- Control room data Data are used to calculate the stoichiometric ratios, thermal efficiency and heat absorption.

- Coal samples Samples are evaluated to determine coal fineness, composition and volatility.

- $\quad$ Ash samples Samples are evaluated to determine carbon-in-ash and loss of ignition.

- In-furnace measurement HVT tests are used to characterize the temperature and flow stratifications in the boiler for comparison with process design models. The HVT is also used to assess $\mathrm{CO}$ distribution.

- Visual observation The potential for slagging and fouling of boiler tubes and other areas of the boiler are assessed. 
Parametric testing is performed using a pre-planned test matrix. The matrix involves various combinations of the five dependent variables listed above to determine the effects on $\mathrm{NO}_{\mathrm{x}}$ emissions and other boiler responses. Evaluation of these results plus consideration of any unique boiler operating constraints are required to approximate the optimal set points for reburning operation. Additional tests are performed using minor adjustments to the dependent variables to fine tune the system. Once the set points are established for various load conditions, the data are entered into the control system providing for an automatic load following capability.

\subsubsection{LNB System}

Optimization of the LNB system is performed in the field during startup wherein the LNB secondary and tertiary air swirl settings are optimized to yield low $\mathrm{NO}_{\mathrm{x}}$ emissions and good carbon burnout over the boiler load range. Normally the longer the coal flame, the less $\mathrm{NO}_{x}$ produced. Considering carbon in the fly ash, the shorter the flame the better the carbon burnout and the lower the carbon monoxide $(\mathrm{CO})$ emissions. Therefore, the final swirl settings for the secondary and tertiary air zones are dictated by these two aspects of combustion.

Another parameter that affects $\mathrm{LNB} \mathrm{NO}_{x}$ reduction performance and carbon burnout is the amount of excess air used. Normally, the lower the excess air, the higher the $\mathrm{NO}_{\mathrm{x}}$ reduction but the higher the carbon in ash and flue gas $\mathrm{CO}$. Therefore, the concentration of oxygen at the exit of the boiler is also a critical operating parameter for the LNB system. A finer grind of coal will normally allow the furnace exit oxygen concentration to be reduced slightly and that will improve $\mathrm{NO}_{\mathrm{x}}$ reduction but also provide for good carbon burnout and low $\mathrm{CO}$ emissions. 


\section{0}

TECHNOLOGY PERFORMANCE

The objective of the test program was to demonstrate the effectiveness of combined GRLNB technology in reducing $\mathrm{NO}_{x}$ emissions from a wall-fired power generating unit. This section presents the results of the demonstration showing the data from both short-term parametric/optimization and long-term tests. The presentation includes First Generation and Second Generation GR plus the results of gas w/gas reburning tests.

\subsection{Baseline Testing}

Baseline testing on Cherokee Unit \#3 was conducted prior to the GR-LNB retrofit. The testing was designed to monitor the daily operation of the boiler and auxiliary equipment under predetermined load conditions in a manner consistent with normal operation. The parameters which were varied during testing were excess $\mathrm{O}_{2}$ and load. No attempt was made to optimize the operation of the boiler before testing, since the purpose was to document the "as found" condition.

A detailed Baseline Test Report was prepared during Phase I and submitted for record. The $\mathrm{NO}_{\mathrm{x}}$ emissions data from the report are summarized in Figures 5-1 for full load conditions, adjusted to a dry $3 \% \mathrm{O}_{2}$ basis.

At near full load (150 $\mathrm{MW}_{\mathrm{e}}$ net) the average emissions measured were:

$\begin{array}{ll}\mathrm{NO}_{x} & 541 \mathrm{ppm}\left(0.73 \mathrm{lb} / 10^{6} \mathrm{Btu}\right) \\ \mathrm{SO}_{2} & 355 \mathrm{ppm} \\ \mathrm{CO} & 67 \mathrm{ppm} \\ \text { Carbon-in-ash } & 4.4 \mathrm{wt} \%\end{array}$



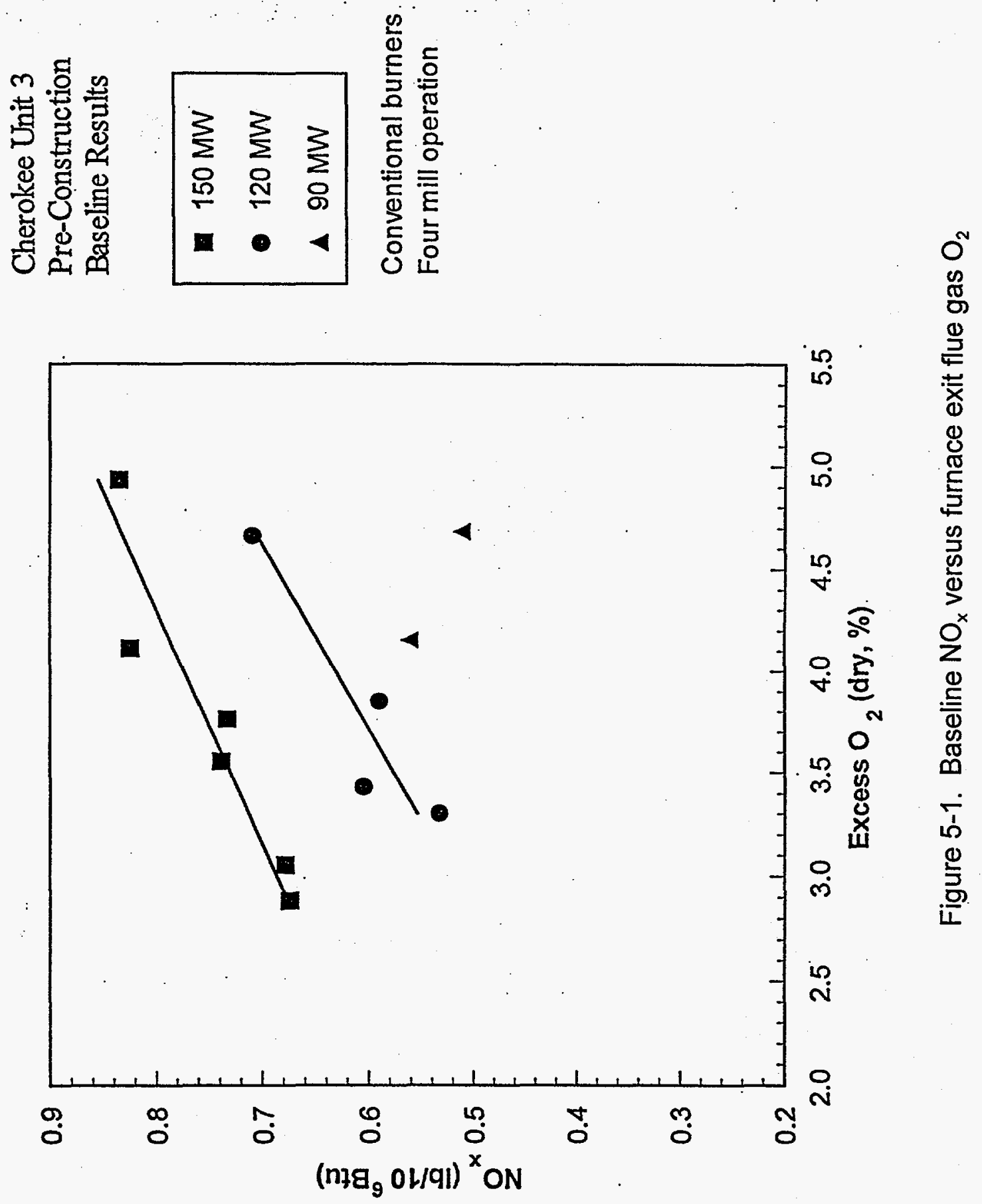
$\mathrm{NO}_{x}$ The baseline $\mathrm{NO}_{x}$ emission levels were considered reasonable and comparable to other wall-fired units of similar design, size and age. As expected, $\mathrm{NO}_{x}$ emissions increased as excess $\mathrm{O}_{2}$ increased.

$\mathrm{SO}_{2}$ The baseline $\mathrm{SO}_{2}$ emission levels were reflective of the low-sulfur coal that was fired.

CO The baseline $\mathrm{CO}$ emission levels increased as excess $\mathrm{O}_{2}$ was decreased. During the tests, in some cases, the $\mathrm{CO}$ emission rates were high. It was believed that the high $\mathrm{CO}$ levels were caused by coal fineness out of specification on three of the four mills and the use of wet coal due to rain occurring during the test program.

$\mathrm{CO}_{2}$ The $\mathrm{CO}_{2}$ levels were typical for the fuel fired.

Carbon-in-ash The carbon-in-ash levels increased with decreasing excess air, but were generally less than $5 \%$.

\section{$5.2 \quad$ LNB Baseline}

The existing sixteen burners were replaced with FWEC internal fuel-staging LNBs. The burners employ dual combustion air registers which allow for control of air distribution at the burner, providing independent control of the ignition zone and flame shape. $A \mathrm{NO}_{x}$ reduction of $45 \%$ from baseline was projected at the full load condition.

The purpose of the baseline test series was to (1) compare the performance with that of the original boiler equipment, and (2) establish stabilized conditions prior to the start of each GR-LNB parametric test. The $\mathrm{NO}_{\mathrm{x}}$ reduction results of the test series is presented in Figure 5-2. 


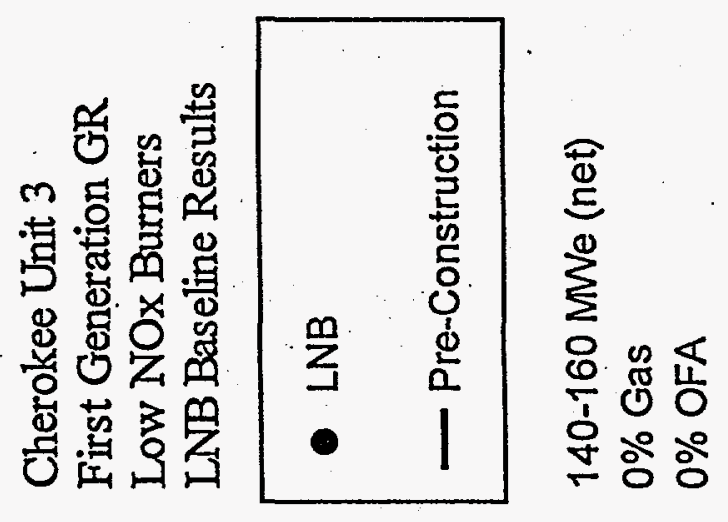

ถึ

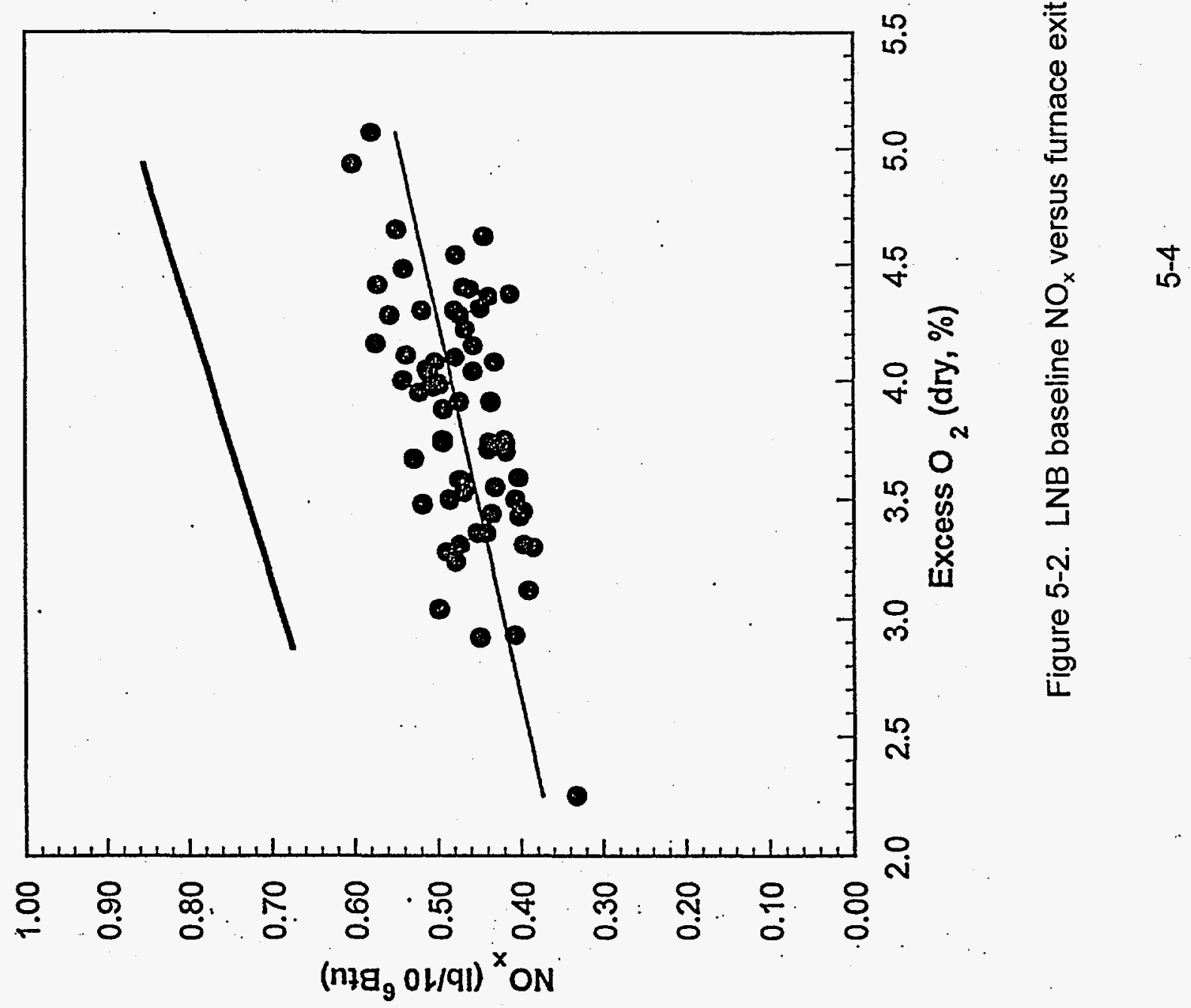


The $\mathrm{NO}_{\mathrm{x}}$ emissions, carbon-in-ash and $\mathrm{CO}$ emissions for LNB only operation are shown below, summarizing the average results and comparing them to the original equipment baseline values:

\begin{tabular}{|c|c|c|c|}
\hline Furnace exit $\mathrm{O}_{2}$ & $3 \%$ & $4 \%$ & $\underline{5 \%}$ \\
\hline \multicolumn{4}{|l|}{$\mathrm{NO}_{\mathrm{x}}\left(\mathrm{lb} / 10^{6} \mathrm{Btu}\right)$} \\
\hline baseline & 0.68 & 0.77 & 0.86 \\
\hline LNB & 0.42 & 0.49 & 0.54 \\
\hline$\%$ change & $-38 \%$ & $-36 \%$ & $-37 \%$ \\
\hline \multicolumn{4}{|l|}{ Carbon-in-ash } \\
\hline baseline & $5 \%$ & $5 \%$ & $4 \%$ \\
\hline LNB & $8 \%$ & $5 \%$ & $2 \%$ \\
\hline \multicolumn{4}{|l|}{$\mathrm{CO}(\mathrm{ppm})$} \\
\hline baseline & $<300$ & $<50$ & $<50$ \\
\hline LNB & $<1000$ & $<500$ & $<100$ \\
\hline
\end{tabular}

The data show that the LNBs reduced $\mathrm{NO}_{x}$ emissions by about $37 \%$. However, carbon-inash and $\mathrm{CO}$ could not be maintained at acceptable levels at the normal excess air level $\left(\sim 3 \% \mathrm{O}_{2}\right)$. By boosting the excess air, the carbon-in-ash and $\mathrm{CO}$ could be lowered to approximately baseline conditions, but at the expense of higher $\mathrm{NO}_{\mathrm{x}}$ emissions. Note that the targeted LNB reduction in $\mathrm{NO}_{x}$ emissions (45\%) was not achieved; the achievement of this level of reduction with LNBs served the basis EER used for predicting an overall $70 \%$ reduction for the GR-LNB system.

The combustion air to the LNBs was varied to establish the relationships between primary zone stoichiometric ratio $\left(\mathrm{SR}_{1}\right)$ and boiler emissions and performance. If $\mathrm{SR}_{1}$ could be reduced, the level of $\mathrm{NO}_{x}$ reduction per amount of reburn fuel added would increase. In addition, reducing $\mathrm{SR}_{1}$ results in lower $\mathrm{NO}_{\mathrm{x}}$ emissions from the burners. The normal operating $\mathrm{SR}_{1}$ for the LNBs was approximately 1.23. When this ratio is lowered there is a reduced level of oxygen available that decreases the formation of fuel bound and thermal $\mathrm{NO}_{x}$ in the primary zone. 
$\mathrm{SR}_{1}$ has a lower limit (unique foreach boiler) to avoid localized pockets of oxygen deficient flue gas, otherwise known as reducing atmospheres, which could result in accelerated corrosion in the lower furnace. It should be noted that there were no indications of reducing atmospheres in the burner zone of the furnace and no evidence of accelerated boiler tube corrosion rates at any time during the test program.

The test results for the series are displayed in Figure 5-3 $\mathrm{NO}_{x}$ versus $\mathrm{SR}_{1}$. As expected, $\mathrm{NO}_{\mathrm{x}}$ emissions were lower when $\mathrm{SR}_{1}$ was reduced. The rate of reduction tapered off as $\mathrm{SR}_{1}$ fell below 1.10. CO for the most part remained below $150 \mathrm{ppm}$, demonstrating that as $\mathrm{SR}_{1}$ is reduced, $\mathrm{CO}$ can be controlled by the OFA ports. A negative impact was the higher level of carbon-in-ash (greater than 7\%). A goal of the GR technology was to avoid increasing the unburned carbon.

\subsection{GR-LNB (First Generation GR)}

The test program was designed to (1) evaluate the impacts of GR-LNB on gaseous emissions, boiler performance and operability, and operating costs, and (2) to determine the boiler set points required to reduce the $\mathrm{NO}_{\mathrm{x}}$ emissions to the program goal of $70 \%$. This section presents the results of the parametric/optimization tests performed on the First Generation GR (w/FGR) system.

Optimization of the GR system was accomplished by systematically varying the process parameters of the system which affect overall $\mathrm{NO}_{\mathrm{x}}$ emissions. The results of each parametric variation was used to establish the basis for the next parametric variation in succession. Thus the testing proceeded in logical fashion until all parameters were varied and their effects evaluated. 

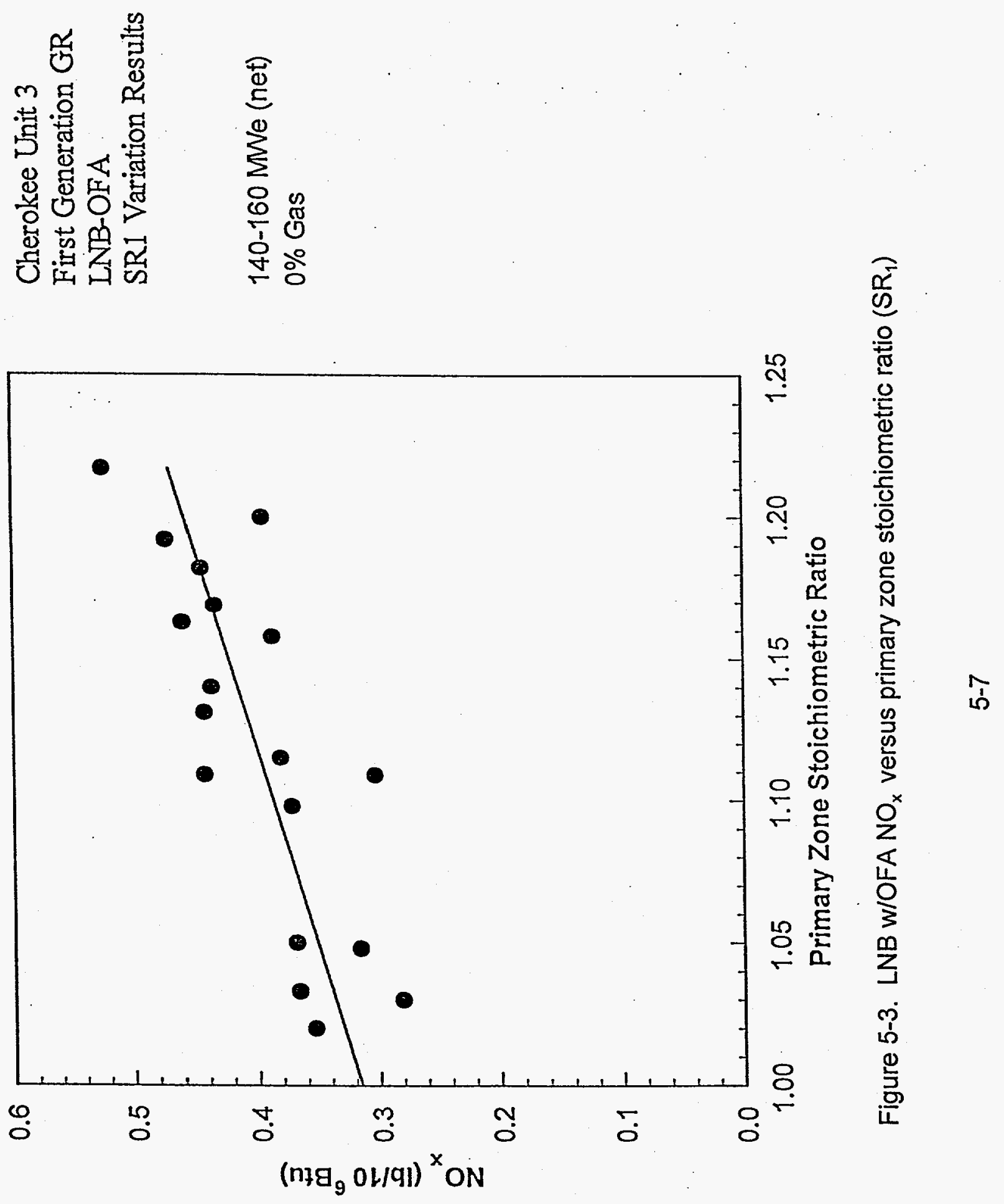
The sequence of testing was as follows:

- $\quad$ LNB emissions were measured without GR in operation and compared to the original baseline.

- $\quad$ The excess air fired in the burners was varied to determine the minimum excess air level at which the burners could be operated commensurate with maintaining acceptable carbon loss and $\mathrm{CO}$ emissions. These tests were performed with and without the OFA system in operation.

- The natural gas was varied to determine the relationship between $\mathrm{NO}_{x}$ emissions and gas heat input. The impact on carbon-in-ash was also assessed. The test series was used to study the effects of changes to the reburn zone stoichiometric ratio on reburn performance.

- The OFA was varied to determine the relationship between $\mathrm{CO}$ and excess air. The test series was used to identify the optimum overall excess air levels for reburn operation.

The majority of the tests were performed at near full load $\left(150 \mathrm{MW}_{\mathrm{e}}\right)$. However, a significant number of tests were performed at reduced load (120 and $90 \mathrm{MW}_{\mathrm{e}}$ ).

\subsubsection{Gas Heat Input Variation}

The tests of variable gas heat input were designed to establish its relationship with $\mathrm{NO}_{\mathbf{x}}$ emissions. $\mathrm{SR}_{2}$ is influenced by the amount of combustion air directed into the primary zone and the amount of gas injected into the reburn zone, measured as a percentage of total heat input to the boiler. Normally, the stoichiometric ratio of the flue gas exiting the primary zone is greater than 1.0. As natural gas is injected into the boiler, this ratio decreases and eventually creates a substoichiometric zone $\left(\mathrm{SR}_{2}<1.0\right)$ that is conducive to $\mathrm{NO}_{\mathrm{x}}$ reduction. As the oxygen concentration in the flue gas entering the reburn zone decreases, less gas is required to reach the optimum reburn zone stoichiometric ratio. Note that $\mathrm{SR}_{2}$ is directly proportional to the gas heat input. 
Small scale results have shown that overall $\mathrm{NO}_{x}$ reductions are highest when $\mathrm{SR}_{2}$ is in the region of 0.90 . Reducing the stoichiometric ratio below this level does not generally produce a significantly higher $\mathrm{NO}_{x}$ reduction. The natural gas flow rate is determined by the lowest attainable operating SR level of the LNBs (including mills out-of-service), and the boiler load.

Figure 5-4 presents the relationship between $\mathrm{NO}_{x}$ emission and gas heat input. Increasing the amount of reburn fuel lowers $\mathrm{NO}_{x}$ emissions. However, the greatest reburning benefit occurs within the first $10 \%$ of gas heat input.

Limited carbon-in-ash data are available. However, the results show that at the more desirable (lower) $\mathrm{SR}_{1}$ the carbon-in-ash is no worse than that of the LNBs. Also, lower values of carbon-in-ash were observed at the higher gas heat input levels.

\subsubsection{Overfire Air (OFA) Variation}

OFA is injected into the boiler to complete combustion of the reburn fuel. OFA is typically 15-20 percent of the total air flow. When applying reburning, it is desirable to minimize the overall excess air level to maintain high thermal efficiencies. However, the OFA must also be adjusted to minimize CO emissions. The OFA flow capacity is bound by (1) the minimum air requirements to consume the remaining combustibles and (2) the maximum air available from the windbox. The OFA variation tests showed, as anticipated, minimal effects on $\mathrm{NO}_{\mathrm{x}}$ emissions.

\subsubsection{Flue Gas Recirculation (FGR) Variation}

In the parametric tests the rate of carrier flue gas was varied from 4,000 to $14,000 \mathrm{scfm}$. The maximum design flow for the reburn fuel carrier flue gas was $3.4 \%$ of total boiler flue gas flow, nominally $12,000 \mathrm{scfm}$. 


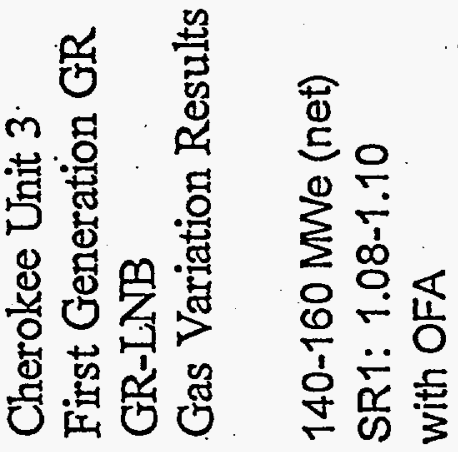

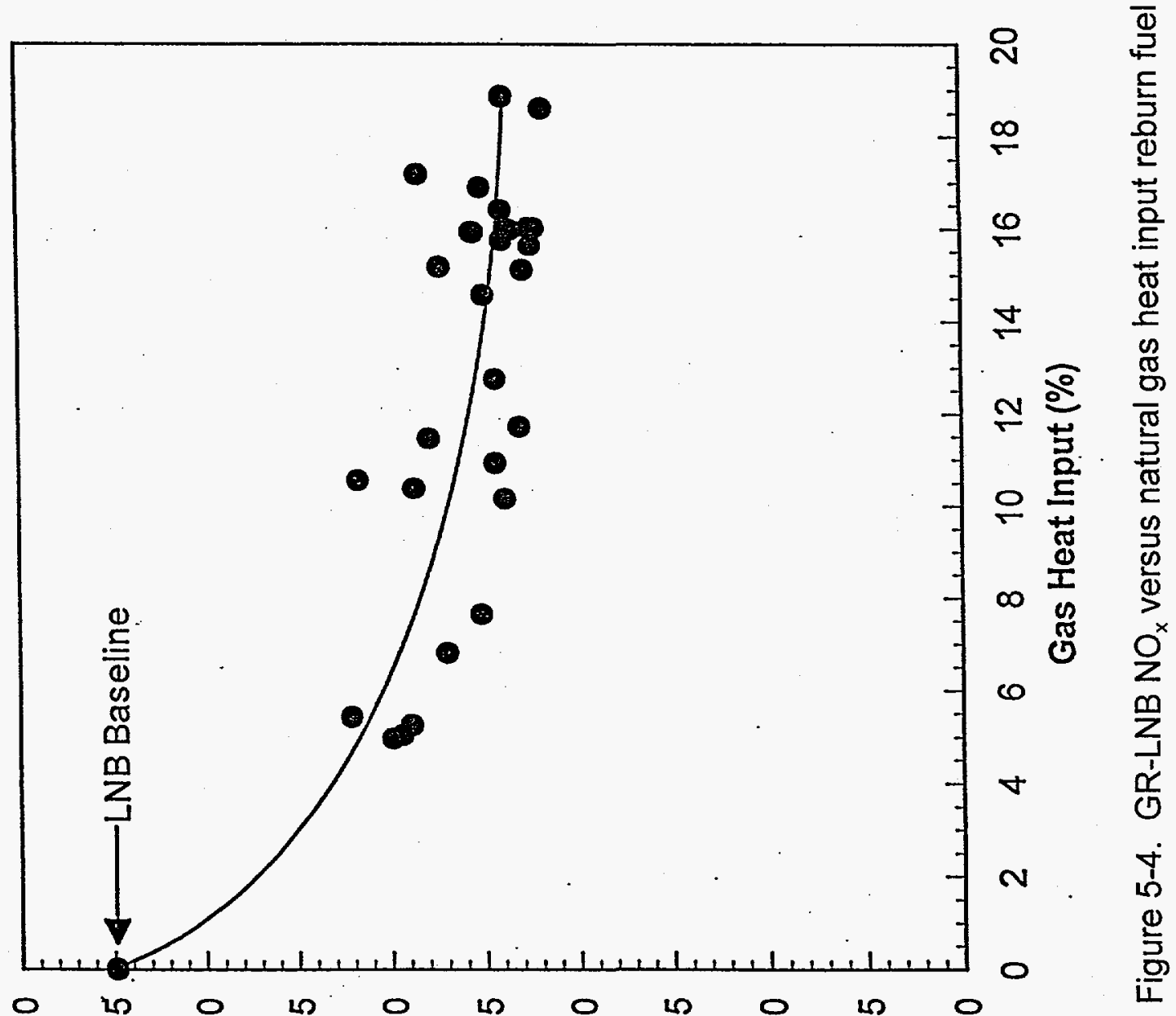

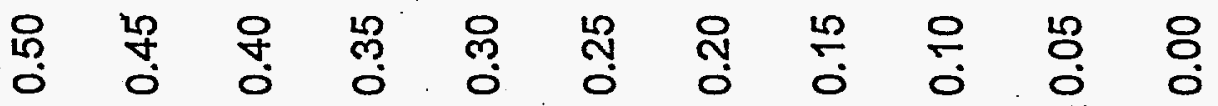
$\left(\mathrm{n}^{\prime} \mathrm{g}_{\mathrm{g}} \mathrm{0L/q1}\right)^{\mathrm{x}} \mathrm{ON}$ 
The effects of the FGR variation are displayed in Figure 5-5. The data show that the quantity of FGR which was injected into the reburn zone had little effect on $\mathrm{NO}_{\mathrm{x}}$ emissions. In the initial stages of the parametric test program, $10,000 \mathrm{scfm}$ was identified as the optimum amount of FGR, but later tests showed that 4,000 scfm was sufficient for good penetration of the reburn fuel into the furnace.

Use of the minimum 4,000 scfm rate of FGR resulted in only slightly less $\mathrm{NO}_{\mathrm{x}}$ reduction. It was demonstrated that any FGR rate in the range of $4,000 \mathrm{scfm}$ to $14,000 \mathrm{scfm}$ (maximum obtainable) could be used for the purpose of reburn fuel injection and for cost reasons, the lower the rate the better. The use of FGR resulted in higher steam attemperation water flow due to the release of heat higher up in the furnace.

\subsubsection{Assessment of Results}

The goals of the GR-LNB project were as follows:

- Reduce $\mathrm{NO}_{x}$ emissions by $70 \%$ from baseline which corresponds to a $\mathrm{NO}_{x}$ emissions level of $0.22 \mathrm{lb} / 10^{6} \mathrm{Btu}(94 \mathrm{mg} / \mathrm{MJ})$

- Maintain the operational integrity of the unit during operation of the GR-LNB system

- Hold CO emissions to acceptable levels (100 ppm or lower)

- Verify the long term operability of the combined technology while operating in the normal power generating mode of unit control by load dispatch over long periods of time

A series of parametric tests were performed to determine the optimum boiler set points that would achieve these goals. The parametric test results are discussed as they were used to establish these set points. 

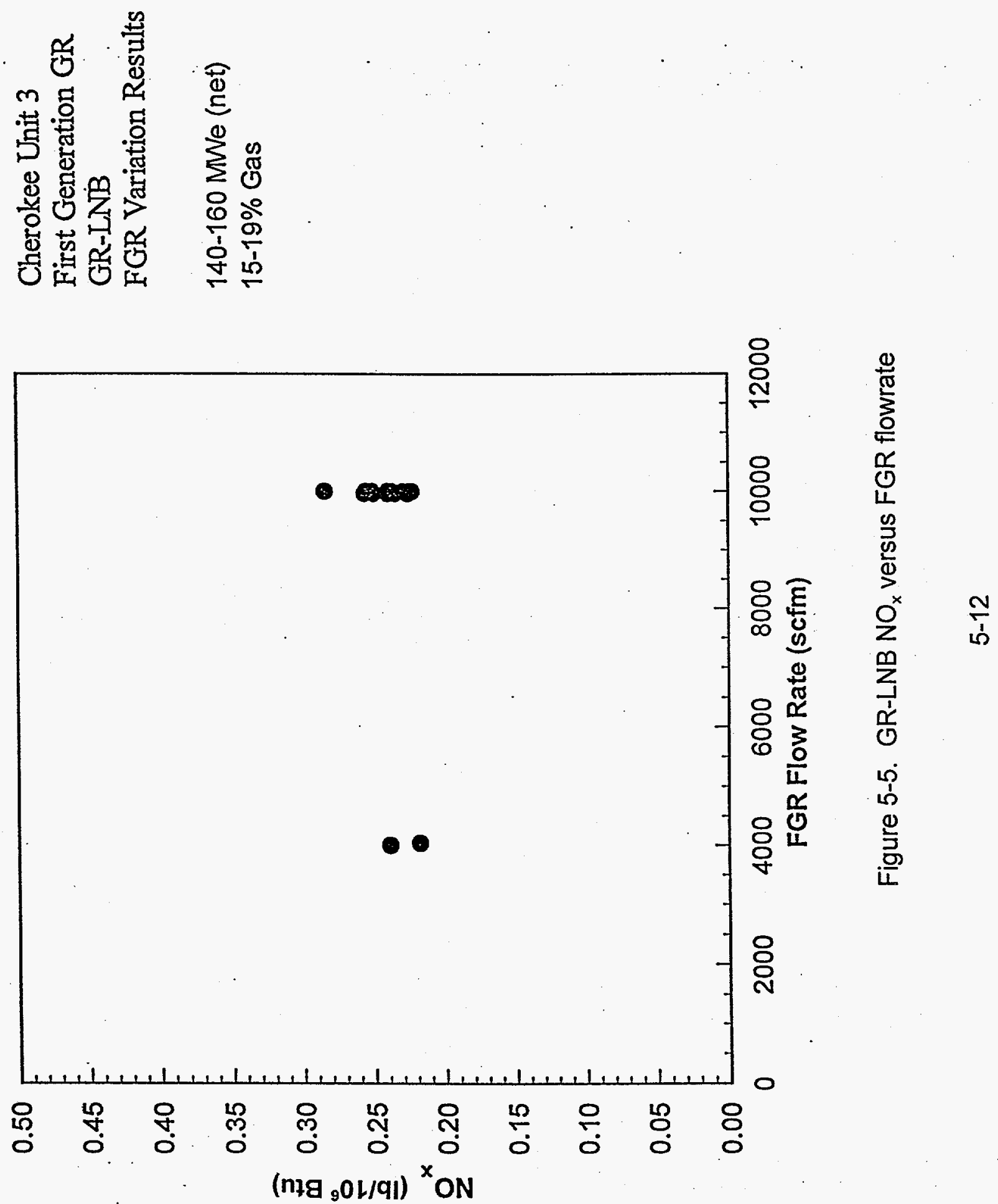
A series of tests were performed with LNBs only and with GR-LNB to determine the lower limit of $S R_{1}$. Note that the lowest attainable level of $S R_{1}$ results in the minimum natural gas usage required to reach the optimum $\mathrm{SR}_{2}$. However, $\mathrm{SR}_{1}$ is lowered at the expense of higher carbon-in-ash. The results of these tests indicated that the optimum $\mathrm{SR}_{1}$ was 1.08 with a carbon-in-ash level of 4.5 wt \%.

As expected, higher gas levels (15-19\%) were required to achieve the $\mathrm{NO}_{x}$ reduction goal. Carbon-in-ash levels were also lower at higher gas levels. To achieve the targeted $\mathrm{SR}_{2}$ level of 0.90 , a gas heat input of $18 \%(4,850 \mathrm{scfm})$ was required. Although a $70 \%$ reduction in $\mathrm{NO}_{x}$ was achieved for short periods of time, the average was $65 \%$. Significantly higher gas heat inputs were required to consistently maintain a $70 \%$ reduction.

Tests of the OFA system indicated that CO was controllable to less than $100 \mathrm{ppm}$ with a $\mathrm{SR}_{3}$ of approximately 1.15 . This corresponds to an air flow of $68,000 \mathrm{scfm}$, which is about $30 \%$ of total air flow to the unit. At low gas flow, $\mathrm{CO}$ emissions were found to be high. Low gas operation requires reduced OFA flow, leading to reduced jet penetration and mixing and elevation of $\mathrm{CO}$ emissions. $\mathrm{CO}$ emissions were also high during operation with LNBs only.

The SR in each zone could vary by about \pm 0.02 with equally effective $\mathrm{NO}_{\mathrm{x}}$ reduction results. The variation in SRs is primarily attributable to the process control systems on the unit. The output of the forced draft (FD) fans that supply combustion air to the unit could easily vary by $\pm 2 \%$ which could produce a variance of \pm 0.02 in the furnace zone SR's. This is not considered an abnormal condition and could occur in most power plants. During the controlled parametric tests, process outputs such as combustion air flow from the FD fans could be adjusted manually. In this way, the desired furnace SRs could be controlled to a target average. 
The results of the parametric testing were used to establish the operating conditions that would yield the desired test objectives. For full load, these conditions were as follows:

$\begin{array}{ll}\mathrm{SR}_{1} & 1.08 \\ \mathrm{SR}_{2} & 0.90 \\ \mathrm{SR}_{3} & 1.15 \\ \text { Gas heat input } & 18 \% \\ \mathrm{FGR} & 4,000-10,000 \mathrm{scfm} \\ \mathrm{OFA} & 68,000 \mathrm{scfm} \\ \mathrm{O}_{2} & 3.25 \% \\ \mathrm{NO}_{\times} & 0.25 \mathrm{lb} / 10^{6} \mathrm{Btu}(107 \mathrm{mg} / \mathrm{MJ}) \\ \mathrm{NO}_{x} \text { reduction } & 66 \% \\ \text { CO } & 43 \mathrm{ppm} \\ \text { Carbon-in-ash } & 4.50 \%\end{array}$

The combined technology GR-LNB proved to be effective, but the total $\mathrm{NO}_{x}$ reduction was not as great as could have been achieved with better LNB performance. LNBs reduced $\mathrm{NO}_{\mathrm{x}}$ emissions by $37 \%$ but never achieved the anticipated reduction of $45 \%$ over the normal load range of 80 to $150 \mathrm{MW}_{\mathrm{e}}$. This diminished the potential $\mathrm{NO}_{\mathrm{x}}$ reduction that could be obtained for the combined GR-LNB system. An estimated $5 \%$ to $10 \%$ decline in the overall system $\mathrm{NO}_{x}$ reduction potential was attributable to the substandard LNB performance.

Also, the sluggish action of the combustion air control valve (old pneumatic type) did not keep the excess air at or near the desired levels during the long term test phase. This resulted in higher than desired excess air levels at times that yielded higher $\mathrm{NO}_{\mathrm{x}}$ emissions. Based on the results of the parametric tests, nominal operating conditions for long term testing were established as follows:

$\begin{array}{ll}\mathrm{SR}_{1} & 1.10 \\ \mathrm{SR}_{2} & 0.90 \\ \mathrm{SR}_{3} & 1.20 \\ \text { Gas heat input } & 18 \%\end{array}$


The long term test series lasted for approximately nine months. During this time the average $\mathrm{NO}_{x}$ reduction was $65 \%$ (Figure 5-6), while $\mathrm{CO}$ was maintained below an emission level of $100 \mathrm{ppm}$. The goal of $70 \% \mathrm{NO}_{x}$ reduction was achieved for short periods when the combustion controls were in manual mode for better control of excess air to the unit. When the unit was operated in the load-following mode, the nominal operating parameters were difficult to maintain and there was a continual variation from the desired operating conditions. The reaction time for changes in the GR set points was about 20 minutes after the demand signal was received. As mentioned, this was due to an antiquated pneumatic bellows arrangement on the combustion air flow valve that did not react quickly enough to changes in air flow demand.

\subsubsection{Reduced Load Testing}

One objective of this project was to demonstrate a GR system that would be effective for $\mathrm{NO}_{\mathrm{x}}$ reduction throughout the entire operating range of the boiler while in load-following mode under dispatch control. Optimization tests were conducted at loads from 60 to 150 $\mathrm{MW}_{\mathrm{e}}$, but it became apparent that the effective operating load range of the boiler was at loads of $70 \mathrm{MW}_{\mathrm{e}}$ and higher. The boiler load range for practical operation of the GR system was 80 to $150 \mathrm{MW}_{\mathrm{e}}$. This was due to the difficulty in maintaining stable loads while operating below $80 \mathrm{MW}_{\mathrm{e}}$ and the necessity to operate the boiler at high levels of excess air to maintain final superheat and reheat steam temperatures.

Boiler load impacts $\mathrm{GR}$ performance in terms of the primary zone $\mathrm{NO}_{x}$ emission level and the furnace gas temperature profile. As load was reduced, the $\mathrm{NO}_{\mathrm{x}}$ formation in the primary zone was reduced as a result of less fuel being burned, and temperatures throughout the furnace were lower due to the reduced thermal input to the boiler. To maintain the main and reheat steam outlet temperatures at reduced loads, excess air was increased, shifting some of the heat transfer within the boiler from the radiant section (furnace tube walls) to the convection passes (superheat/reheat tube banks). 


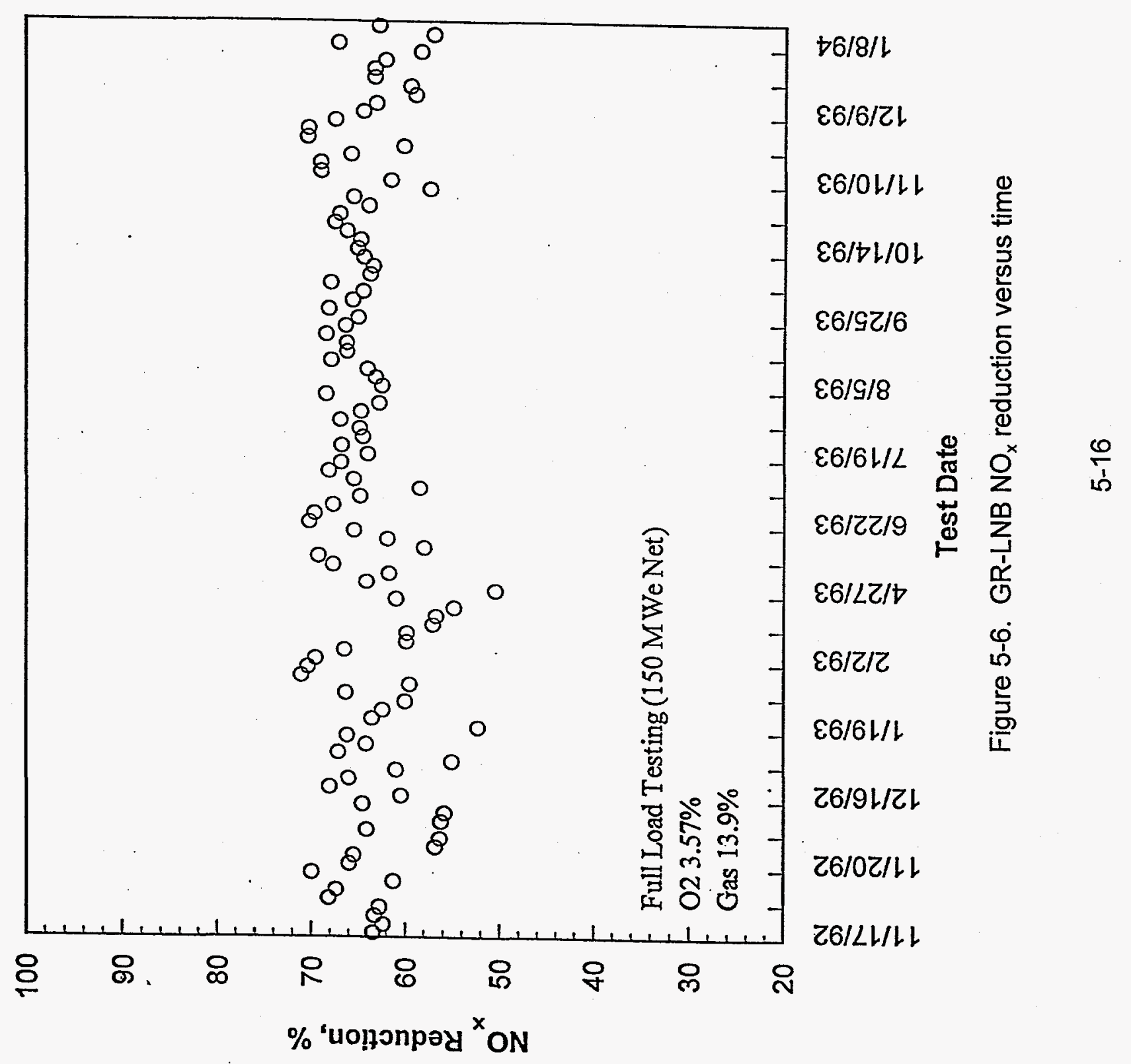


Design data showed that lower $\mathrm{NO}_{\mathrm{x}}$ levels and lower gas temperatures entering the reburning zone resulted in a decrease in the overall $\mathrm{GR}$ system $\mathrm{NO}_{x}$ reduction performance on a percentage basis from baseline levels. This was confirmed during the optimization testing.

Figure 5-7 shows $\mathrm{NO}_{\mathrm{x}}$ emission levels as a function of gas heat input for the boiler operating load range. The results show that $\mathrm{NO}_{x}$ emission reductions decreased as load was reduced. However, $\mathrm{NO}_{x}$ emission levels remained near $0.20 \mathrm{lb} / 10^{6} \mathrm{Btu}$.

At Cherokee Unit \#3, the normal mode of operation is to have all four mills in service at full load and to have three mills in service for loads below $120 \mathrm{MW}_{\mathrm{e}}$. Operation with less than three mills resulted in unstable boiler operating conditions. The burners are fed by mills $\mathrm{D}$ to $\mathrm{A}$, from the top row to the bottom row. Tests were conducted at $120 \mathrm{MW}_{\mathrm{e}}$ and 150 $M_{\mathrm{e}}$ with $\mathrm{D}$ mill and its associated top row of burners out of service to determine the operational effects of combustion staging in combination with GR. To obtain full load with D mill out of service, it was necessary to inject a total of about $20 \%$ natural gas in the GR system.

The effect of combustion staging at full load was about a six percent improvement in $\mathrm{NO}_{\mathrm{x}}$ reduction, from $66 \%$ with four mill operation to $72 \%$ with three mill operation. A greater $\mathrm{NO}_{x}$ reduction was expected from combustion staging with $\mathrm{GR}$, but the previously discussed performance problems with the LNBs probably prevented combustion staging from being more effective in reducing $\mathrm{NO}_{x}$ emissions. Also, excess air fluctuations were experienced during testing which probably had a negative impact on the results. An indication of combustion problems during the three mill operation test was high carbon-inash which ranged from 6 to $9 \%$. 

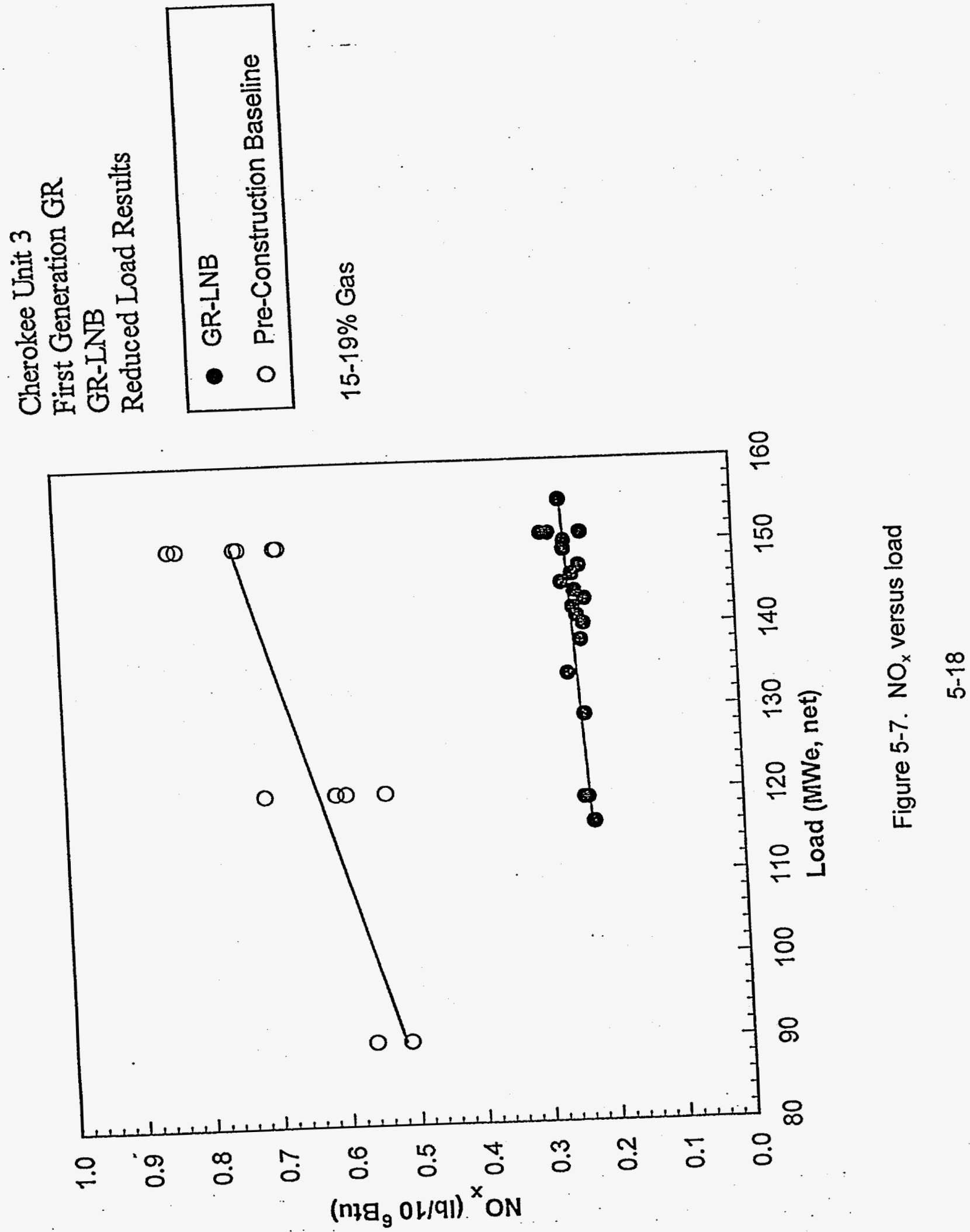
Limited testing was conducted_at three mill operation because of Unit \#3 operational problems and the requirement by dispatch management for full load operation during the time period scheduled for this testing.

\section{$5.4 \quad$ GR-LNB (Second Generation GR)}

FGR was used initially to provide momentum to the natural gas to achieve optimum boiler penetration and mixing. However, it was determined that the FGR had minimal effect on $\mathrm{NO}_{x}$ emissions. Certain problems associated with the FGR ash removal system made it attractive to consider a re-design of the gas injection system in order to eliminate the need for FGR altogether. The small amount of FGR required to transport the gas into the boiler, along with the lower amount of gas required for effective $\mathrm{NO}_{x}$ reduction, led to this decision.

It was determined that a gas injection pressure in the range of 1 to 5 psig would adequately penetrate and cover the cross-sectional area of the furnace to provide the necessary reducing conditions in the reburn zone. This eliminated the need for the FGR booster fans, duct work, and the multiclone dust collectors. The elimination of FGR will result in significant cost savings on future GR system installations.

A second series of tests was added to evaluate the modified configuration and judge its impact. This technology is referred to as Second Generation GR and is described as follows:

- The FGR system, originally designed to provide momentum to the natural gas, was removed. The change would result in reduced capital costs on future designs.

- Natural gas injection was optimized at $13 \%$ gas heat input, compared to the First Generation operating value of $18 \%$. FGR elimination required incorporation of high velocity jet injectors that made good use of the available 
natural gas pressure. The change resulted in reduced operating cost due to lower gas usage.

- The OFA ports were modified to provide higher jet momentum, especially at low total flows.

- $\quad$ The OFA ports were also modified to provide air swirl capability and velocity control. The modification was designed to improve lateral coverage of the furnace and turbulence in mixing with unburned fuel. This change provided CO control at lower gas levels, which was a concern with the First Generation design.

Prior to startup of the modified system, Foster Wheeler performed some modification work on the LNBs in an attempt to improve their $\mathrm{NO}_{x}$ reduction performance. The first tests following startup characterized the LNBs without GR in operation.

\subsubsection{LNB Modifications}

At the start of each Second Generation GR parametric test, the conditions of the boiler were stabilized before the data were taken. Data taken at the end of these startup periods were used as baseline data, since only LNBs were in operation during the start of each test. The results were used to compare the performance of originally-installed LNBs with the modified LNBs. Figure 5-8 presents a chart of $\mathrm{NO}_{x}$ versus excess air for LNB operation. Compared to the originally-installed LNB's and at an excess air level of $3.5 \%$, the $\mathrm{NO}_{x}$ emissions showed a favorable improvement of $11 \%$.

Compared to the conventional burners at the same excess air, the $\mathrm{NO}_{\mathrm{x}}$ emissions were reduced by $44 \%$, which was an improvement from the LNB baseline. However, the CO and carbon-in-ash levels were still unacceptably high. CO was in the 100-200 ppm range and carbon-in-ash was as high as $8 \%$. Also, long flames persisted in the upper furnace region. Although the burner modifications now reduced $\mathrm{NO}_{\mathrm{x}}$ emissions to the near target level of $45 \%$, the performance was unacceptable from a $\mathrm{CO}$ and carbon-in-ash standpoint. 

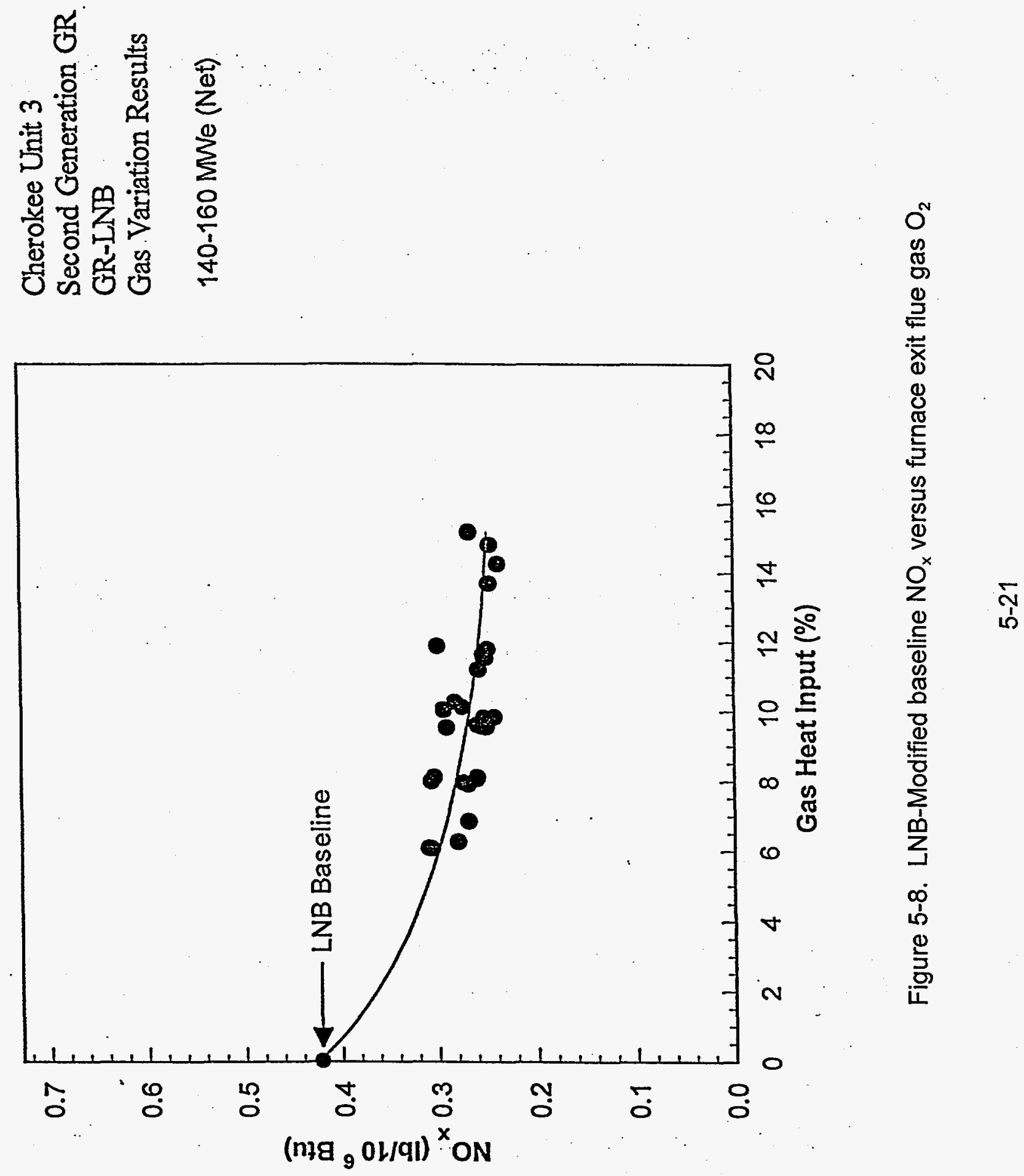


\subsubsection{Modified GR-LNB System}

The results of the Second Generation GR-LNB test series are shown in Figure 5-9. The $\mathrm{NO}_{x}$ vs. gas heat input plot shows increased $\mathrm{NO}_{x}$ reduction as the level of gas increases, again similar to First Generation GR. At a gas heat input level of $12.5 \%$, the $\mathrm{NO}_{x}$ level was $0.26 \mathrm{lb} / 10^{6} \mathrm{Btu}$ ( $64 \%$ reduction). Carbon-in-ash levels were at or below the preconstruction baseline levels when the excess $\mathrm{O}_{2}$ was above $3.5 \%$. CO levels were somewhat higher than First Generation GR, but approximated the pre-construction levels when excess $\mathrm{O}_{2}$ was above $3.5 \%$.

Extended GR-LNB tests were conducted to verify the system performance. The tests were conducted both at constant loads and with the system under dispatch operation, where unit load was adjusted in order to meet the varying plant electrical output requirements. The load would vary from about 80 to $155 \mathrm{MW}_{e}$ based on grid demand. The tests ranged in duration from one hour to several days. The results of long term testing are presented in Figure 5-10. As the figure shows, there was no relative change in $\mathrm{NO}_{\mathrm{x}}$ emissions reduction between First and Second Generation GR, even with a reduced gas level.

\subsubsection{Assessment of Results}

FGR was used initially to provide momentum to the natural gas to achieve good boiler penetration. During long term testing it was determined that the FGR had minimal effect on $\mathrm{NO}_{x}$ emissions. Therefore, a second test series was added to evaluate the modified configuration and gage its impact. This Second Generation GR modifications included:

\footnotetext{
- Removal of the FGR system

- Installation of high velocity gas injectors
} 

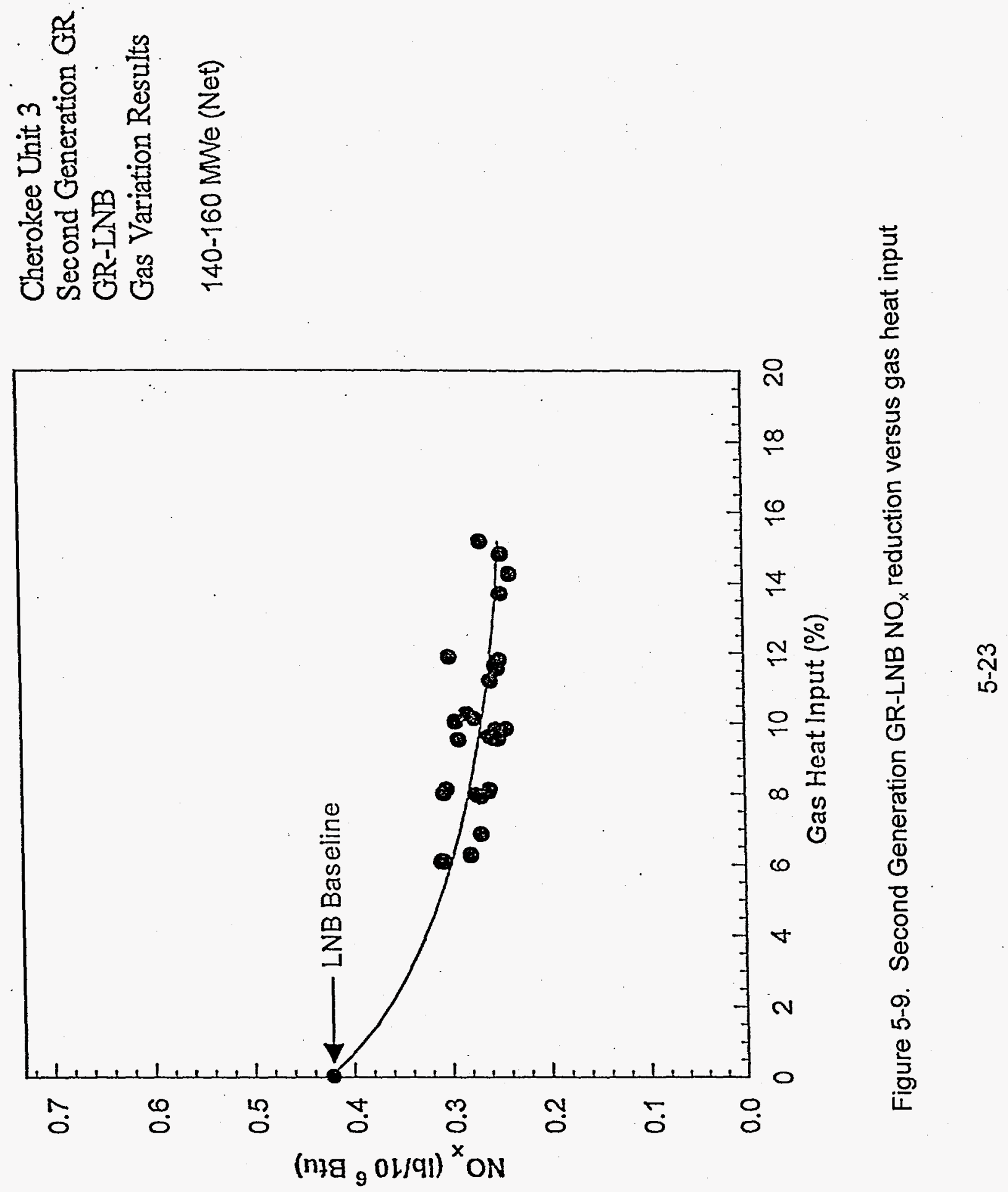


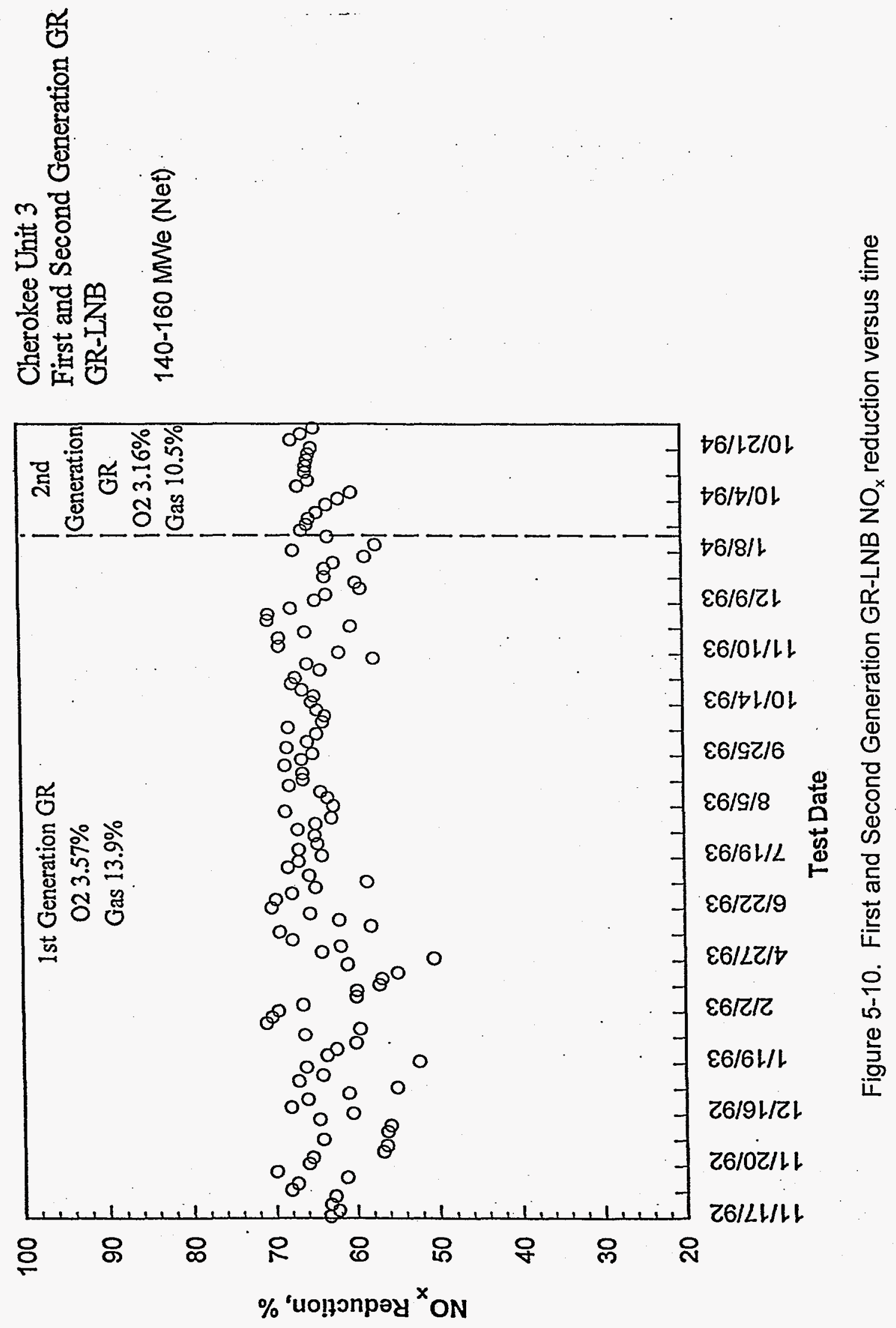


- Modifications to the OFA ports to provide higher jet momentum, air swirl capability and velocity control. The modifications were designed to improve furnace lateral coverage and turbulence in mixing with unburned fuel. This change provided CO control within acceptable limits at the lower gas levels.

The Second Generation GR was designed to provide performance and economic benefits compared to the First Generation GR. These include:

- Reduced capital cost through elimination of the FGR system

- Reduced operating cost through reduction in the gas heat input

- The same $\mathrm{NO}_{\mathrm{x}}$ reduction as First Generation $\mathrm{GR}$ with less gas

- Reduced levels of $\mathrm{CO}$ at low natural gas flows

Through LNB equipment modifications the $\mathrm{NO}_{x}$ emission reductions increased somewhat. No change was indicated in $\mathrm{CO}$ emissions. There was only a slight reduction in GR-LNB $\mathrm{NO}_{x}$ emissions from an average of $65 \%$ to an average of $64 \%$ but with less natural gas. At higher gas levels, $68 \%$ was achieved. A gas heat input of $12.5 \%$ was selected for Second Generation GR testing, which was a reduction of $5.5 \%$ from First Generation GR. The $\mathrm{SR}_{2}$ setting of 0.90 was maintained, but $\mathrm{SR}_{1}$ was reduced to compensate for the reduced level of gas heat input. Compared to LNB only, $\mathrm{CO}$ emissions were reduced when the GR system was in service. The results show that modified GR-LNB technology achieved excellent emissions reductions and all goals of the Second Generation GR system were achieved. The test results are summarized below:

First Gen.

Gas heat input

Baseline $\mathrm{NO}_{\mathrm{x}}$

Average $\mathrm{NO}_{x}$ reduction (LNB)

Average $\mathrm{NO}_{x}$ reduction (GR-LNB)
$18 \%$

$0.73 \mathrm{lb} / 10^{6} \mathrm{Btu}$

$37 \%$

$65 \%$
Second Gen.

$12.5 \%$

$0.73 \mathrm{lb} / 10^{6} \mathrm{Btu}$

$44 \%$

$64 \%$ 


\subsection{Gas/Gas Reburning Testing}

A limited amount of GR testing was performed with the boiler operating on $100 \%$ natural gas (no coal) to determine the reduction in $\mathrm{NO}_{\mathrm{x}}$ and assess the impact on $\mathrm{CO}$ emissions. The primary fuel (natural gas) was fired through the LNBs and gas also injected into the reburning zone. No equipment modifications were made to operate in this configuration.

The $\mathrm{NO}_{x}$ emissions results for full load are presented in Figures 5-11 and 5-12. The data show a reduction from a baseline of $0.30 \mathrm{lb} / 10^{6} \mathrm{Btu}$ to $0.17 \mathrm{lb} / 10^{6} \mathrm{Btu}(43 \%)$ at a reburning gas heat input of $7 \%$. For the most part, $\mathrm{CO}$ emissions were below $100 \mathrm{ppm}$. The baseline ( $100 \%$ gas/no reburning) and optimum gas/gas reburning conditions for full load were as follows:

$\begin{array}{lcc} & \text { Baseline } & \text { Optimum } \\ \mathrm{SR}_{1} & 1.15 & 1.03 \\ \mathrm{SR}_{2} & 1.15 & 0.94 \\ \mathrm{SR}_{3} & 1.16 & 1.17 \\ \text { Reburn Gas heat input } & 0 \% & 7 \% \\ \mathrm{O}_{2} & 3.06 \% & 2.36 \% \\ \mathrm{NO}_{\mathrm{x}} & 0.30 \mathrm{lb} / 10^{6} \mathrm{Btu} & 0.17 \mathrm{lb} / 10^{6} \mathrm{Btu} \\ \mathrm{NO}_{\mathrm{x}} \text { reduction } & 0 \% & 43 \% \\ \mathrm{CO} & 2 \mathrm{ppm} & 32 \mathrm{ppm}\end{array}$

At mid-load $\left(120 \mathrm{MW}_{\mathrm{e}}\right.$ ) the $\mathrm{NO}_{\mathrm{x}}$ was reduced from $0.22 \mathrm{lb} / 10^{6}$ Btu to $0.11 \mathrm{lb} / 10^{6} \mathrm{Btu}$ at $8 \%$ reburning gas heat input and $\mathrm{CO}$ at $80 \mathrm{ppm}$. At low load the $\mathrm{NO}_{x}$ was reduced from 0.10 $\mathrm{lb} / 10^{6} \mathrm{Btu}$ to $0.06 \mathrm{lb} / 10^{6} \mathrm{Btu}$ at $6 \%$ reburning gas heat input and $\mathrm{CO}$ at $52 \mathrm{ppm}$.

The normal test configuration was injection of reburning gas through the 8 rear wall injectors. However, some full-load injector biasing testing was performed. Shifting half of the gas to the front wall showed no change in $\mathrm{NO}_{\mathrm{x}}$ emissions, although an increase in $\mathrm{CO}$ was observed. When using all 16 injectors ( 8 front and 8 rear) and $12 \%$ gas, $\mathrm{NO}_{x}$ emissions remained the same as for $7 \%$ gas, but the $\mathrm{CO}$ emissions increased dramatically. 

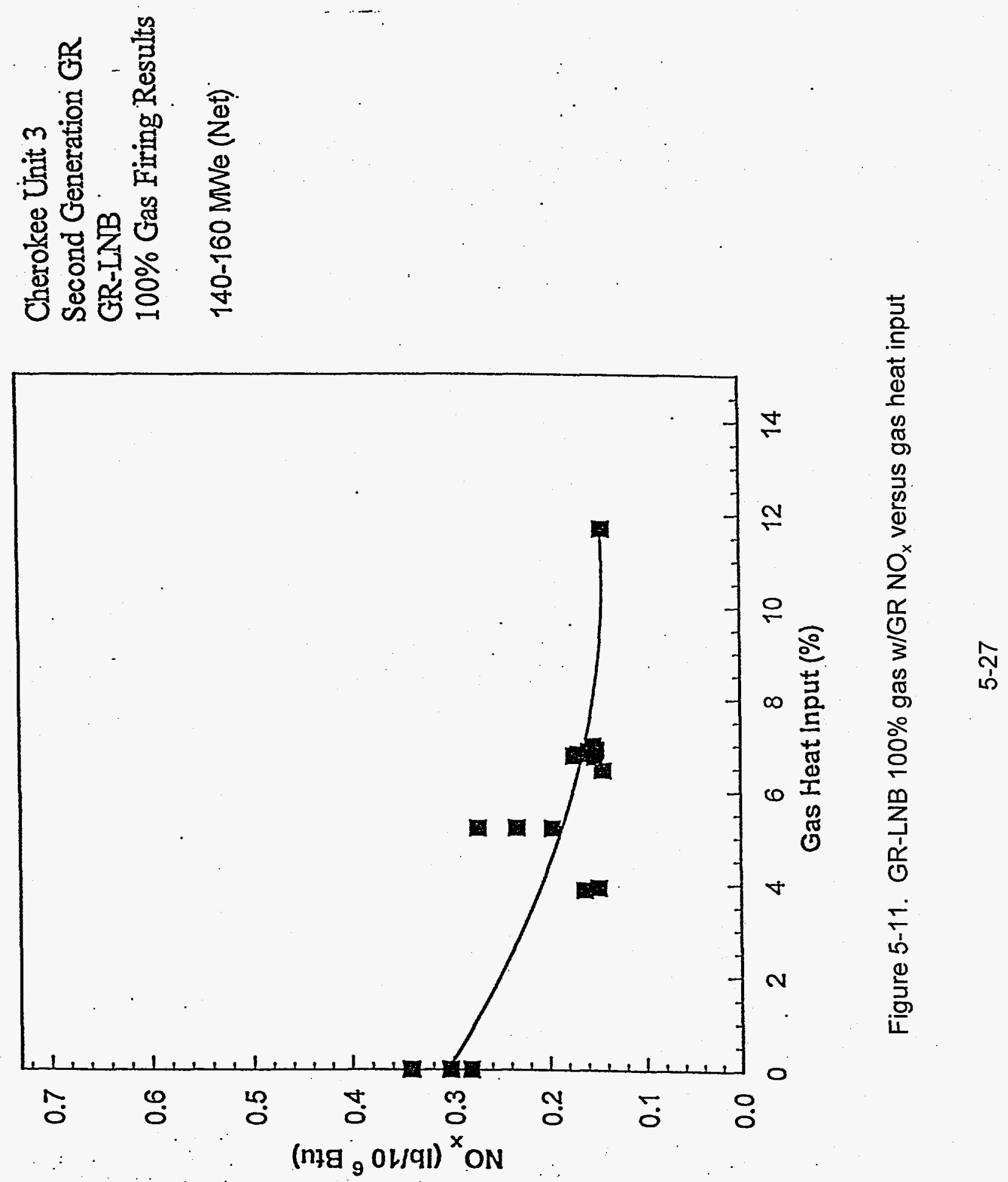
Lower load biasing tests showed similar results. Therefore, the optimum configuration was to use the 8 rear wall injectors only.

The gas-firing with gas reburning results showed that a reduction in $\mathrm{NO}_{x}$ emissions can be achieved using reburn technology on a $100 \%$ gas-fired system while maintaining levels of CO emissions below $100 \mathrm{ppm}$. 


\subsection{BOILER IMPACTS}

\subsection{Thermal Performance}

The impacts of GR-LNB on boiler thermal performance and efficiency were projected in the process design study. The study predicted that the unit would produce steam at its rated capacity during GR-LNB, but with a slightly lower thermal efficiency. Also, there would be minor changes in the heat absorption profile.

During the parametric and long term testing, data were collected to compare the GR-LNB results with baseline data and also for comparison with the projections. Tables 6-1 through 6-3 present these data for both First and Second Generation LNB and GR-LNB operation over the boiler load operating range. The data were collected and evaluated to ensure that the unit operated under full load at its rated capacity with proper steam temperatures and to verify that there were no adverse impacts on steam conditions/heat absorption.

Furnace Exit $\mathrm{O}_{2}$ The average $\mathrm{O}_{2}$ observed during non-test baseline conditions prior to installation of the GR-LNB system was $3.2 \%$. Following installation of the LNBs, the unit was operated at $2.85 \%$ under full load but was returned to the $3.2 \% \mathrm{O}_{2}$ level following LNB modifications to lower $\mathrm{CO}$ emissions during the LNB only tests. For both the First and Second GR-LNB system operations the excess $\mathrm{O}_{2}$ under full load conditions was controlled at about $2.6 \%$.

Steam Side Temperatures As predicted in the process design, increases were observed in both the main and reheat steam temperatures. This was due to the modified heat distribution in the boiler when the GR system is in operation. The increase was lessened with Second Generation GR since the amount of gas heat input was reduced. Steam temperatures were adequately controlled through steam attemperation. 
TABLE 6-1. THERMAL PERFORMANCE SUMMARY (Full Load - $150 \mathrm{MW}_{\mathrm{e}}$ )

\begin{tabular}{|c|c|c|c|c|}
\hline \multirow{2}{*}{ Thermal Parameters } & \multicolumn{2}{|c|}{ LNB } & \multicolumn{2}{|c|}{ GR-LNB } \\
\hline & 1 st Gen. & 2nd Gen. & 1st Gen. & 2nd Gen. \\
\hline \multicolumn{5}{|l|}{ Process variables } \\
\hline Exit Plant 02 & 2.85 & 3.21 & 2.63 & 2.60 \\
\hline Gas heat input (\%) & & & 13.72 & 10.23 \\
\hline OFA ( $\%$ total air) & & & 19.86 & 22.30 \\
\hline \multicolumn{5}{|l|}{ Steam side temperatures (deg. F) } \\
\hline Main steam temperature & 969 & 971 & 992 & 985 \\
\hline Hot reheat temperature & 945 & 946 & 984 & 964 \\
\hline Attemperator outlet temperature (deg. F) & 774 & 782 & 778 & 785 \\
\hline \multicolumn{5}{|l|}{ Heat transfer $\left(10^{\wedge} 6 \mathrm{Btu} / \mathrm{hr}\right)$} \\
\hline Furnace & 743 & 747 & 712 & 737 \\
\hline Secondary superheater & 164 & 160 & 173 & 165 \\
\hline Reheater & 163 & 157 & 169 & 153 \\
\hline Primary superheater & 231 & 238 & 231 & 239 \\
\hline Air heater & 193 & 192 & 190 & 184 \\
\hline Economizer & 29 & 30 & 29 & 31 \\
\hline \multicolumn{5}{|l|}{ Cleanliness factors } \\
\hline Furnace & 1.028 & 1.025 & 1.009 & 1.026 \\
\hline Secondary superheater & 1.038 & 0.999 & 1.118 & 1.045 \\
\hline Reheater & 0.901 & 0.861 & 0.958 & 0.849 \\
\hline Primary superheater & 1.034 & 1.053 & 1.067 & 1.077 \\
\hline Air heater & 1.045 & 1.032 & 1.061 & 1.005 \\
\hline Economizer & 1.022 & 1.047 & 1.024 & 1.075 \\
\hline Econ. gas outlet temp. (deg. F) & 699 & 707 & 713 & 707 \\
\hline \multicolumn{5}{|l|}{ Heat loss (\%) } \\
\hline Dry gas & 5.00 & 4.90 & 4.80 & 4.60 \\
\hline Moisture from fuel & 1.11 & 1.11 & 0.96 & 0.99 \\
\hline Moisture from combustion & 4.26 & 4.25 & 5.14 & 4.90 \\
\hline Combustible in refuse & 0.61 & 0.61 & 0.53 & 0.55 \\
\hline Radiation & 0.19 & 0.19 & 0.21 & 0.20 \\
\hline Unmeasured & 0.83 & 0.81 & 0.86 & 0.83 \\
\hline ASME' heat loss efficiency (\%) & 88.00 & 88.13 & 87.51 & 87.93 \\
\hline Net heat rate (Btu/kWh) & 10,208 & 10,153 & 10,104 & 10,103 \\
\hline
\end{tabular}


TABLE 6-2. THERMAL PERFORMANCE SUMMARY (Mid Load - $120 \mathrm{MW}_{\mathrm{e}}$ )

\begin{tabular}{|c|c|c|c|c|}
\hline \multirow{2}{*}{ Thermal Parameters } & \multicolumn{2}{|c|}{ LNB } & \multicolumn{2}{|c|}{ GR-LNB } \\
\hline & 1 st Gen. & 2nd Gen. & 1st Gen. & 2nd Gen. \\
\hline \multicolumn{5}{|l|}{ Process variables } \\
\hline Exit Plant $\mathrm{O} 2$ & 3.07 & 3.80 & $3.30^{\circ}$ & 3.33 \\
\hline Gas heat input (\%) & & & 14.25 & 9.39 \\
\hline OFA ( $\%$ total air) & & & 21.32 & 22.87 \\
\hline \multicolumn{5}{|l|}{ Steam side temperatures (deg. F) } \\
\hline Main steam temperature & 974 & 964 & 989 & 969 \\
\hline Hot reheat temperature & 926 & 910 & 958 & 941 \\
\hline Attemperator outlet temperature (deg. F) & 760 & 777 & 773 & 771 \\
\hline \multicolumn{5}{|l|}{ Heat transfer $\left(10^{\wedge} 6 \mathrm{Btu} / \mathrm{hr}\right)$} \\
\hline Furnace & 608 & 585 & 595 & 660 \\
\hline Secondary superheater & 140 & 116 & 139 & 142 \\
\hline Reheater & 131 & 118 & 136 & 132 \\
\hline Primary superheater & 166 & 173 & 180 & 192 \\
\hline Air heater & 156 & 152 & 163 & 165 \\
\hline Economizer & 22 & 26 & 22 & 30 \\
\hline \multicolumn{5}{|l|}{ Cleanliness factors } \\
\hline Furnace & 1.046 & 1.039 & 1.024 & 1.052 \\
\hline Secondary superheater & 1.083 & 0.924 & 1.073 & 1.025 \\
\hline Reheater & 0.907 & 0.884 & 0.945 & 0.844 \\
\hline Primary superheater & 0.986 & 1.071 & 1.071 & 1.036 \\
\hline Air heater & 1.092 & 1.098 & 1.139 & 1.052 \\
\hline Economizer & 1.027 & 1.252 & 1.034 & 1.255 \\
\hline Econ. gas outlet temp. (deg. F) & 667 & 678 & 689 & 690 \\
\hline \multicolumn{5}{|l|}{ Heat loss $(\%)$} \\
\hline Dry gas & 5.06 & 4.88 & 5.04 & 4.43 \\
\hline Moisture from fuel & 1.11 & 1.10 & 0.95 & 0.99 \\
\hline Moisture from combustion & 4.26 & 4.24 & 5.17 & 4.82 \\
\hline Combustible in refuse & 0.61 & 0.61 & 0.52 & 0.50 \\
\hline Radiation & 0.29 & 0.31 & 0.29 & 0.26 \\
\hline Unmeasured & 1.12 & 1.16 & 1.13 & 1.03 \\
\hline ASME heat loss efficiency $(\%)$ & 87.55 & 87.70 & 86.90 & 87.92 \\
\hline Net heat rate (Btu/kWh) & 10,303 & 10,143 & 10,275 & 10,617 \\
\hline
\end{tabular}


TABLE 6-3. THERMAL PERFORMANCE SUMMARY (Low Load - $90 \mathrm{MW}_{\mathrm{e}}$ )

\begin{tabular}{|c|c|c|c|c|}
\hline \multirow{2}{*}{ Thermal Parameters } & \multicolumn{2}{|c|}{ LNB } & \multicolumn{2}{|c|}{ GR-LNB } \\
\hline & 1st Gen. & 2nd Gen. & 1st Gen. & 2nd Gen. \\
\hline \multicolumn{5}{|l|}{ Process variables } \\
\hline Exit Plant $\mathrm{O} 2$ & 3.87 & 4.69 & 4.03 & 5.00 \\
\hline Gas heat input (\%) & & & 15.32 & 10.95 \\
\hline OFA (\% total air) & & & 23.55 & 25.86 \\
\hline \multicolumn{5}{|l|}{ Steam side temperatures (deg. F) } \\
\hline Main steam temperature & 956 & 998 & 978 & 980 \\
\hline Hot reheat temperature & 906 & 974 & 930 & 930 \\
\hline Attemperator outlet temperature (deg. F) & 752 & 782 & 760 & 772 \\
\hline \multicolumn{5}{|l|}{ Heat transfer $\left(10^{\wedge} 6 \mathrm{Btu} / \mathrm{hr}\right)^{\circ}$} \\
\hline Furnace & 486 & 483 & 474 & 497 \\
\hline Secondary superheater & 103 & 104 & 107 & 104 \\
\hline Reheater & 109 & 104 & 111 & 98 \\
\hline Primary superheater & 124 & 144 & 129 & 137 \\
\hline Air heater & 126 & 136 & 133 & 134 \\
\hline Economizer & 17 & 24 & 16 & 25 \\
\hline \multicolumn{5}{|l|}{ Cleanliness factors } \\
\hline Furnace & 4.040 & 1.036 & 1.027 & 1.049 \\
\hline Secondary superheater & 0.972 & 0.991 & 1.022 & 0.973 \\
\hline Reheater & 0.960 & 0.917 & 0.987 & 0.845 \\
\hline Primary superheater & 1.013 & 1.173 & 1.070 & 1.098 \\
\hline Air heater & 1.153 & 1.240 & 1.229 & 1.195 \\
\hline Economizer & 1.063 & 1.558 & 1.060 & 1.550 \\
\hline Econ. gas outlet temp. (deg. F) & 648 & 67 & 666 & 665 \\
\hline \multicolumn{5}{|l|}{ Heat loss $(\%)$} \\
\hline Dry gas & 5.28 & 4.67 & 5.59 & 4.73 \\
\hline Moisture from fuel & 1.11 & .1 .09 & 0.94 & 0.97 \\
\hline Moisture from combustion & 4.26 & 4.21 & 5.25 & 4.90 \\
\hline Combustible in refuse & 0.61 & 0.61 & 0.52 & 0.54 \\
\hline Radiation & 0.37 & 0.37 & 0.38 & 0.37 \\
\hline Unmeasured & 1.37 & 1.37 & 1.38 & 1.35 \\
\hline ASME heat loss efficiency (\%) & 87.00 & 87.68 & 85.95 & 87.12 \\
\hline Net heat rate (Bțu/kWh) & 10,954 & 10,871 & 10,858 & 11,182 \\
\hline
\end{tabular}


Heat Transfer GR operation cann affect the thermal performance by altering the furnace heat release profile and by changing the local stoichiometric ratios and particulate loading resulting in minor changes in lower and upper furnace deposition patterns. Although heat transfer in the furnace was reduced and the heat transfer in the superheater and reheater increased during First Generation GR, the heat transfers improved considerably with the Second Generation GR. The furnace temperature in the reburn zone affects the rate of $\mathrm{NO}_{x}$ reduction. Higher temperatures increase the rate of speed of the chemical reactions that result in $\mathrm{NO}_{\mathrm{x}}$ destruction. The temperatures attained in the reburn zone were typically $2300^{\circ}$ to $2500^{\circ} \mathrm{F}$, which are consistent with the predicted reburn zone temperatures.

ASME Heat Loss A reduction in thermal efficiency was calculated using ASME Power Test Code 4.1 (heat loss method). A slight reduction in efficiency was observed with GRLNB as compared to LNB-only due to dry gas heat loss, moisture in fuel heat loss, and heat loss due to moisture from combustion. The decrease in heat absorption and resulting rise in the flue gas temperature increases the dry gas heat loss, especially for GR-LNB operation. Fuel switching, i.e. replacement of coal heat with heat from natural gas, results in a reduction in boiler efficiency due to increased fuel moisture heat loss. Since natural gas has a higher hydrogen-to-carbon ratio than coal, its combustion results in the formation of more moisture and consequently higher moisture from combustion heat loss. Nevertheless, the total reduction in efficiency was less than $1 \%$ for all conditions.

\subsection{Furnace Conditions}

GR operation did not exacerbate slagging in the furnace. Long term operation of the $G R$ system did not show any trend toward additional slagging or fouling beyond that which occurred when operating without GR in service. Some slagging was noted around the LNBs, but this was attributed to the abnormal functioning of the burners. Later in the test program, one LNB (D3) nozzle and internals melted, evidently due to combustion inside the burner. 
In the reburn zone, slag formed around some of the gas injection nozzles on a random basis, but this did not cause a problem with the reburn gas injection system performance. The injection nozzles were designed with a removable inspection cover and clean out port to determine if the gas injection nozzle tip was plugged.

Generally, no more than two gas nozzles per wall would be plugged at a time, and usually only one nozzle per wall would require slag removal. When a nozzle did become plugged, it was a simple matter to "rod"'out the nozzle and remove the slag from the nozzle orifice.

In the OFA zone, heavy slag deposits formed around three of the six OFA injectors after about three months of operation. The initiation of the slag formation was attributed to higher flue gas temperatures in this area with GR in operation. The air injected through the OFA ports would "chill" the slag so that it would solidify at this location. The unrestrained buildup of slag progressed over time due to a lack of sootblowers in this area of the furnace. Slag would build up on the refractory around the ports, and without sootblowers in place for removal, the deposits would continue to grow until a significant "eyebrow" would form and solidify around the port. These deposits were removed during regularly scheduled outages.

In the convection pass of the boiler, the bridging of slag deposits in the secondary superheater section occurred when flames from the LNBs swept up into this area. It was difficult to keep the LNB flames at the correct length, and they were generally too long and would bounce off the rear wall and continue up to the arch region at the exit of the furnace. When the FWEC personnel adjusted the burners for proper operation, this usually did not occur. It should be noted that the phenomenon of flames reaching the upper regions of the furnace occurred independent of GR operation.

The overall conclusion is that GR does not have a significant adverse impact upon boiler operation. The slagging and fouling that occurred did not significantly impact GR operation 
or performance. However, LNB operation did contribute to slagging in the primary burner zone and in the secondary superheater sections.

\subsection{Tubewear}

During reburning, a reducing or fuel-rich condition is established in the reburning zone. It is well known that fuel-rich conditions can enhance tube wastage due to two mechanisms:

- When fuels containing sulfur are burned under oxygen deficient conditions, some of the sulfur forms reduced sulfur species such as COS and $\mathrm{H}_{2} \mathrm{~S}$. These species react with iron in the tubes via $\mathrm{Fe}$ and $\mathrm{H}_{2} \mathrm{~S}-\mathrm{FeS}$. The FeS scales off the tube leading to wastage (corrosion).

- In normal fuel lean operation, the tubes are protected by a thin oxidized layer. Reducing conditions, particularly fluctuating (oxidizing/reducing) conditions, can continuously degrade this protective layer.

Normal rates of tube wastage in coal-fired boilers are normally in the range of $0.001 "$ to 0.003 " per year; however, some boilers inherently have massive tube wastage. As part of the field demonstration described above, the boiler tubes were subjected to nondestructive testing to determine if GR operation jeopardized the life of the tubes. Specific areas were targeted for investigation where the mechanisms listed above suggested a potential for significant tube wastage. The prime goal of the testing was to determine if there was a significant increase in tubewall wastage from GR-LNB. A secondary goal was to determine the incremental change in the tube thickness and project this change to the end of the boiler useful life.

Ultrasonic tube thickness measurements were obtained at two time points: in January 16, 1990 prior to GR startup, and in February 21, 1993 following parametric GR testing. Based on the accuracy of the measurement technique $\left( \pm 0.005^{\prime \prime}\right)$, no significant tube wastage was found. Given these results and the favorable results of two previous EER DOE-CCT projects involving GR, EER and the utility determined that no further testing was warranted. 


\subsection{Additional Observātions}

A multiclone mechanical dust collector system had been installed to remove the flyash from the FGR. However, one problem with this ash removal system was the recurring need to unplug the multiclones periodically to remove the collected fly ash. The multiclone and associated piping were mounted at a second floor location which made removal of the flyash very difficult. Also, during winter months when the ambient temperature was below $32^{\circ} \mathrm{F}$, moisture in the fly ash would freeze and plug the multiclone. This problem was later obviated when the gas injection and OFA systems were redesigned. The new high pressure gas injection system eliminated the need for FGR.

Temperature measurements were conducted to determine the gas temperature profile in the furnace at points leaving the primary zone, the reburn zone, and the burnout zone. A very limited number of boiler penetration locations were available for obtaining temperature measurement in the primary zone. The following average furnace gas temperature profiles were obtained from full load tests:

\section{Coal Firing (no GR) $\quad 19 \%$ Gas Heat Input (GR)}

$\begin{array}{lll}\text { Primary zone } & 2541{ }^{\circ} \mathrm{F} & 2389^{\circ} \mathrm{F} \\ \text { Reburn zone } & 2381{ }^{\circ} \mathrm{F} & 2453^{\circ} \mathrm{F} \\ \text { Burnout zone } & 1840^{\circ} \mathrm{F} & 1917^{\circ} \mathrm{F}\end{array}$

The temperatures displayed for the various zones are the average of all temperatures measured for a given test. As shown from the above data, the gas temperature profile was shifted upwards in the furnace, with the GR system in operation. With GR in operation, the primary zone temperature dropped about $150^{\circ} \mathrm{F}$ while the reburn and burnout zones increased in gas temperature by about $70^{\circ} \mathrm{F}$ and $60^{\circ} \mathrm{F}$ respectively. This is the expected result with the GR system in operation, since some of the heat input is shifted from the primary zone to the reburn zone. The temperature profile tabulated above was recorded during the test with the greatest $\mathrm{NO}_{x}$ reduction performance for the GR system. 


\subsection{ECONOMICS}

This section provides the estimated costs of installation, operation and performance for commercial installation of GR-LNB on a $300 \mathrm{MW}_{\mathrm{e}}$ wall-fired boiler. The estimate is based on mature technology; i.e., a so-called "nth" plant which incorporates process improvements resulting from experience gained in earlier installations. The economics presented here relect the Second Generation GR technology wherein FGR is not required.

The capital and operating costs for the GR-LNB system for $\mathrm{NO}_{x}$ emissions reduction are based on a retrofit of a $300 \mathrm{MW}_{\mathrm{e}}$ wall-fired power plant. The degree of complexity regarding retrofit costs were factored based on the retrofit cost for the GR-LNB demonstration completed under this DOE contract.

\subsection{GR-LNB Economic Parameters}

The capital cost estimates presented summarize major equipment cost, approximate bulk material take-offs, and installation labor to arrive at direct construction costs. Construction indirects are added which include: field supervision, construction overhead and fee, and freight. In addition, costs for detailed engineering, project management, procurement, construction management, startup, and contingency are included to develop the total installed system cost.

All engineering and construction costs are representative of a turn-key contract arrangement. EER considers these estimates to be Class II, Preliminary Estimates. The estimates are expected to be representative of the actual cost $-15 \% /+30 \%$. This is based on the information available at this time which includes preliminary process design and conceptual engineering completed, recent major equipment quotes, bulk material takeoff's and average expected labor rates and productivity. 
This section provides the basis for the estimating procedures, along with a list of assumptions used for estimating installation man-hours and costs. The cost estimates have been developed using the following sources of information for equipment pricing and for the development of labor costs:

- Richardson's Rapid System 1993 edition of Process Plant Construction Estimating Standards

- Questimate Cost Estimating software by Icarus Corp.

- Means Electrical Cost Data 1991 edition

- Vendor Quotations for Major Equipment

- $\quad$ EER's database of previous equipment purchases

Data from all of these sources were summarized using EER cost estimating software. Once the direct costs were determined, costs for field supervision, contractor overhead and fee, freight, engineering, project management, construction management, start-up, and contingency were added to determine the total installed cost. Table 7-1 shows the cost parameters for developing the capital cost of the installed retrofit of the GR-LNB system on a $300 \mathrm{MW}_{\mathrm{e}}$ wall-fired unit. These values are commonly encountered in economic calculations and were used in recent studies of CCT processes by the U.S. Department of Energy. No changes were made to the parameters proposed by DOE.

\subsection{GR-LNB Capital Cost}

The design of the GR-LNB system included three integrated systems: 1) low $\mathrm{NO}_{\mathrm{x}}$ burners, 2) natural gas injection and 3) OFA injection. It is further based on the Second Generation GR design wherein FGR is eliminated. Existing conventional burners are removed and replaced with low $\mathrm{NO}_{x}$ burners. A natural gas header was assumed to exist at the station and a tie-in was made to this supply header to provide the natural gas for the GR system. 
TABLE 7-1. COST FACTORS

\begin{tabular}{|l|c|c||}
\hline \multicolumn{1}{|c|}{ Item } & Units & Value \\
\hline Cost of debt & $\%$ & 8.5 \\
\hline Inflation rate & $\%$ & 4.0 \\
\hline Construction period & mos. & 9 \\
\hline Remaining life of power plant & - & 15 \\
\hline Year for cost presented in this report & - & 1996 \\
\hline Royalty allowance based on total process capital & $\%$ & 0.5 \\
\hline Capital charge factor - current dollars & - & 0.160 \\
\hline Capital charge factor - constant dollars & - & 0.124 \\
\hline O\&M cost levelization factor - current dollars & - & 1.314 \\
\hline O\&M cost levelization factor - constant dollars & - & 1.000 \\
\hline Power plant size & MW $(n e t)$ & 300 \\
\hline Power plant type & Wall-fired & - \\
\hline Power plant capacity factor & $\%$ & 65 \\
\hline Property Taxes and Insurance & $\%$ & 3 \\
\hline Sales tax rate & $\%$ & 5.0 \\
\hline Cost of freight & $\%$ & 2.0 \\
\hline Engineering/home office fees of total process capital & $\%$ & 10.0 \\
\hline \hline
\end{tabular}

The tie-in pipe supplied gas to a control and metering station and from this station natural gas was distributed to gas injection nozzles located above the low $\mathrm{NO}_{\mathrm{x}}$ burners. The natural gas valve train, common to all of the injection nozzles, included flow metering and control equipment, and safety shut-off valves. 
OFA was assumed supplied from the existing hot secondary combustion air windbox. The existing windbox pressure on a wall-fired unit may not be adequate, so booster fans were assumed to be required. The installation of the natural gas injectors and OFA ports requires furnace tubewall modifications. There are no unusual boiler access hindrances that would inhibit normal installation of equipment. No asbestos removal is required during installation. The reburning system is assumed to be installed during a normally scheduled plant outage, negating downtown costs. A list of the major equipment associated with the GR-LNB retrofit in shown in Table 7-2. The sizes and quantities shown are for a standard $300 \mathrm{MW}_{\mathrm{e}}$ unit.

\section{TABLE 7-2. MAJOR EQUIPMENT LIST}

\begin{tabular}{|c|c|c|c|c|c|c|}
\hline \multirow{2}{*}{$\begin{array}{l}\text { Item } \\
\text { No. }\end{array}$} & \multirow[b]{2}{*}{ Item Name } & \multicolumn{2}{|c|}{ Number } & \multirow{2}{*}{$\begin{array}{c}\text { Unit } \\
\text { Capacity }\end{array}$} & \multirow{2}{*}{$\begin{array}{c}\text { Design } \\
\text { Conditions* }\end{array}$} & \multirow{2}{*}{$\begin{array}{c}\text { Material of } \\
\text { Construction }\end{array}$} \\
\hline & & In Use & Spare & & & \\
\hline 1 & Low NOx Burner & 30 & 0 & $\begin{array}{l}100 \times 10^{6} \\
\text { Btu/burner }\end{array}$ & & Steel \\
\hline $2 a$ & $\begin{array}{c}\text { Natural Gas } \\
\text { Delivery System }\end{array}$ & 1 & 0 & $\begin{array}{c}3,840 \text { scfm } \\
60 \text { psi }\end{array}$ & $\begin{array}{l}\text { National Electric Code } \\
\text { Class 1, Division } 2\end{array}$ & Miscellaneous \\
\hline $2 b$ & Natural Gas Injector & 16 & 0 & $\begin{array}{l}240 \text { scfm/ } \\
\text { injector }\end{array}$ & & Steel \\
\hline $3 a$ & Overfire Air System & 1 & 0 & $200,000 \mathrm{scfm}$ & & Miscellaneous \\
\hline $3 b$ & $\begin{array}{l}\text { Overfire Air } \\
\text { Booster Fan }\end{array}$ & 1 & 0 & $200,000 \mathrm{scfm}$ & & \\
\hline $3 c$ & Overfire Air Injector & 8 & 0 & $\begin{array}{l}15,000 \mathrm{scfm} / \\
\text { injector }\end{array}$ & & Steel \\
\hline 4 & Control System & 1 & 0 & $\mathrm{n} / \mathrm{a}$ & & (Electronic) \\
\hline
\end{tabular}

Table 7-3 shows the major equipment costs. The total cost for the major equipment items of the GR-LNB system is $\$ 2.31$ million. This cost estimate is slightly less than the cost presented in the Performance And Economics Report. It assumes that the windbox pressure is adequate to provide cooling air to the natural gas injectors and the cost presented in the Performance and Economics Report includes the installation of a separate cooling fan. Table 7-4 presents the overall capital cost for the GR-LNB system. This cost 
includes both equipment and installation costs. The total cost, including a $15 \%$ project contingency, is at $\$ 7.70$ million or $\$ 25.66 / \mathrm{kW}_{\mathrm{e}}$. The GR and LNB system capital costs can be easily separated from one another for they are independent systems. The capital cost for the GR system only is estimated at $\$ 3.54$ million or $\$ 11.79 / \mathrm{kW}_{\mathrm{e}}$, and the LNB system capital cost is estimated at $\$ 4.16$ million or $\$ 13.87 / \mathrm{kW}_{\mathrm{e}}$.

TABLE 7-3. MAJOR EQUIPMENT COST

\begin{tabular}{|c|c|c|c|c|c|c|}
\hline \multirow{2}{*}{$\begin{array}{c}\text { Item } \\
\text { No. }\end{array}$} & $\begin{array}{c}\text { Item } \\
\text { Name }\end{array}$ & \begin{tabular}{c}
$|c|$ \\
F.O.B. \\
\cline { 3 - 6 }
\end{tabular} & $\begin{array}{c}\text { Sales } \\
\text { Tax } \\
(5 \%)\end{array}$ & Total & \multirow{2}{*}{$\begin{array}{c}\text { No. of } \\
\text { Units }\end{array}$} & $\begin{array}{c}\text { Total } \\
\text { Cost } \\
\mathbf{\$ 1 , 0 0 0 s}\end{array}$ \\
\hline 1 & Low NOx Burners & 55.7 & 2.8 & 58.5 & 30 & $1,754.6$ \\
\hline 2 & $\begin{array}{c}\text { Natural Gas Injectors \& } \\
\text { Tubewall Penetrations }\end{array}$ & 5.1 & 0.3 & 5.4 & 8 & 42.8 \\
\hline 3a & Overfire Air Booster Fan & 351.8 & 17.6 & 369.4 & 1 & 369.4 \\
\hline 3b & $\begin{array}{c}\text { Overfire Air Injectors \& } \\
\text { Tubewall Penetrations }\end{array}$ & 17.4 & 0.9 & 18.3 & 8 & 146.2 \\
\hline & Total & 430.0 & 21.5 & 451.5 & 1 & $\mathbf{2 , 3 1 2 . 9}$ \\
\hline
\end{tabular}

\subsection{GR-LNB Operating Cost}

EER conducted an analysis to evaluate the fixed and variable operating costs of a GR system, exclusive of fixed charges, for a $300 \mathrm{MW}_{\mathrm{e}}$ coal wall-fired unit (heat rate of 10,000 Btu/kWhr before GR-LNB); contributing cost factors were as follows:

1. Reburning Fuel Cost Differential Since gas costs more than coal on a heating value basis $\left(\$ / 10^{6} \mathrm{Btu}\right)$, there is a cost related to the amount of gas fired. This was calculated based on the delivered costs of gas and coal, the percentage of gas fired $\left(12.5 \%\right.$ of the total heat input). A value of $\$ 1.00 / 10^{6} \mathrm{Btu}$ was used as the differential between the delivered price of natural gas $\left(\$ 2.47 / 10^{6} \mathrm{Btu}\right)$ and the delivered price of coal $\left(\$ 1.47 / 10^{6} \mathrm{Btu}\right)$. 


\section{TABLE.7-4. GR-LNB CAPITAL COST}

\section{Capital Cost}

Category

Equipment

Construction Labor

Construction Indirects

Other $(6 \%)$, Freight $(2 \%) \&$ Taxes $(5 \%)$

Gas Supply ${ }^{[1]}$

Gas Metering \& Reduction Station

Total Process Capital

Engineering (10\% of process capital)

Project Management (8\%) /Owners Costs (5\%)

Project Contingency@15\%

Total Plant Cost

Allowance for Funds During Construction [2]

Total Plant Investment (TPI)

Royalty Fees @ 0.5\% of Total Process Capital

Startup Costs @ 3\% TPI

Working Capital @ 0.9\% TPI

Cost of Construction Downtime (28 days) ${ }^{[3]}$

Total Capital Requirement

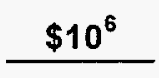

2.46

1.23

0.76

0.32

0.00

0.45

5.22

0.52

0.68

0.96

7.38

0.00

7.38

0.03

0.22

0.07

0.00

7.70
$\$ / k W e$

8.20

4.10

2.53

1.07

0.00

1.50

17.40

1.74

2.26

3.21

24.61

0.00

24.61

0.09

0.74

0.22

0.00

25.66

[1] Gas supply availability at site assumed adequate

[2] No allowance included based on DOE guideline

[3] Assumed downtime to be during scheduled major outage 
2. Changes in Boiler Efficiency Since the boiler efficiency is lower when using gas as the reburning fuel there needs to be an increase in the amount of fuel fired. This increase was based upon the boiler efficiency loss ( $0.80 \% \mathrm{w} / 12.5 \%$ gas) for $\mathrm{GR}$ and a composite fuel cost of $\$ 1.60 / 10^{6}$ Btu.

3. Auxiliary Power Since the GR fuel contributes a significant portion of the boiler fuel, there is a corresponding percentage decreased load on the coal pulverizers. However, there is added power required for the natural gas and OFA cooling air fans. The electricity cost was based on an auxiliary power cost of $\$ 0.02 / \mathrm{kWhr}$.

4. Operating Labor All reburning system operation is performed in the automatic control mode. Therefore, no additional plant operators are required.

5. Maintenance Items/Spare Parts An allowance of $2 \%$ of the total plant investment was used for total maintenance; $40 \%$ of the $2 \%$ was allocated for maintenance items and spare parts. Since the LNBs are replacement units, no additional maintenance cost is included for this equipment.

6. Maintenance Labor An allowance of $2 \%$ of the total plant investment was used for total maintenance; $60 \%$ of the $2 \%$ was allocated for maintenance labor. No additional labor is required to operate the GR-LNB system; however, additional maintenance is required due to the added equipment.

7. Administration and General Overhead An allowance of $60 \%$ of plant labor was added to cover administration and general overhead.

8. Local Property Taxes and Insurance An allowance of $3 \%$ of total plant investment was used to cover taxes and insurance.

The total annual incremental gross operating cost for the GR-LNB system, excluding fixed charges to payback capital, is estimated at $\$ 2.59$ million (see Table 7-5). If an $\mathrm{SO}_{2}$ allowance credit is taken based on the reduction of fuel sulfur when firing natural gas, the net operating cost is estimated at about $\$ 2.10$ million. This $\mathrm{SO}_{2}$ credit was based on an allowance of $\$ 95 /$ ton (Feb. 1996). Variable operating cost for the GR-LNB is about $\$ 2.26$ million and the fixed cost, excluding fixed charges, is about $\$ 0.33$ million. 


\section{TABLE 7.5 GR-LNB OPERATING COST}

\section{Annual Incremental Operating Costs ${ }^{[1]}$}

Annual Use

\section{Variable Costs}

Fuel:

Natural Gas

Supplemental Fuel

Utilities:

Electricity ${ }^{[4]}$

Ash Disposal Credit

Sub-Total
Cost/Unit

Cost/Yr

\section{Fixed Costs}

Labor: ${ }^{[5]}$

Maintenance ( $2 \%$ of GR TPI $\times 60 \%$ )

$\$ 41,930$

Supervision ( $20 \%$ of Maintenance Labor)

$$
\begin{aligned}
& \$ 1.00 / 10^{6} \mathrm{Btu}^{[2]} \\
& \$ 1.60 / 10^{6} \mathrm{Btu}^{[3]}
\end{aligned}
$$

$\$ 217,966$

$136,65610^{6} \mathrm{Btu}$

(769) $10^{3} \mathrm{kWhr}$

$(8,541)$ tons
$\$ 20.00 / 10^{3} \mathrm{kWhr}$

$\$ 9.29$ /ton
$(\$ 15,374)$

$(\$ 79,346)$

Supplies:

Maintenance ( $2 \%$ of GR TPI $\times 40 \%$ )

Admin. and Gen. Ovhd. (60\% of total labor)

Local Taxes and Insurance @ 3\% of TPI

Sub-Total

Total Gross Operating Cost

SO2 Allowance @ \$95/ton ${ }^{[6]}$

\section{Total Net Operating Cost}

[1] 65\% Capacity factor @ 300 MWe net capacity $(10,000$ Btu/kWhr heat rate) w/ 12.5\% fuel heat input as natural gas

[2] Natural gas assumed delivered at $\$ 2.47 / \mathrm{MM}$ Btu; coal cost at $\$ 1.47 / \mathrm{MM}$ Btu

[3] Extra fuel added to make up for loss in efficiency $(0.80 \%)$ at same coal/gas ratio as reburn

[4] OFA booster fan power requirement ( $480 \mathrm{kWhr} @ 65 \%$ capacity), less pulverizer credit of $10 \mathrm{kWhr} / \mathrm{ton}$ coal

[5] Assumed no added operating labor. No incremental maintenance costs for LNBs since they are repalcement parts

[6] February 1996 Allowance Credit Value, reduction based on $4.8 \mathrm{lb} \mathrm{SO} / \mathrm{MM}$ Btu for coal w/coal reduction of $12.5 \%$ 


\subsection{Summary of Performance and Economics}

Based on the developed capital and fixed/variable operating costs, economic projections were made using current dollars which include an inflation rate of $4.0 \%$, and constant dollars which ignore inflation. The factors used in the development of the technology economics are shown in Table 7-1.

Table 7-6 shows the performance and cost for a $300 \mathrm{MW}_{\mathrm{e}}$ GR-LNB System that is retrofitted to a wall-fired boiler. The table reflects the $\mathrm{NO}_{x}$ reduction ( $64 \%$ or 3,990 TPY) costs based on a $65 \%$ capacity factor for the unit with $12.5 \%$ of the heat input supplied by natural gas at a gas to coal price differential of $\$ 1.00 /$ million Btu. The incremental increase in the levelized cost of power, including capital charges is estimated at $2.07 \mathrm{mills} / \mathrm{kWhr}$ in constant dollars and $2.71 \mathrm{mills} / \mathrm{kWhr}$ in current dollars.

If an $\mathrm{SO}_{2}$ credit is applied based on fuel sulfur reduction when firing natural gas, the net incremental increase in the levelized cost of power is estimated at $1.79 \mathrm{mills} / \mathrm{kWhr}$ in constant dollars and 2.34 mills/kWhr in current dollars. The levelized cost of $\mathrm{NO}_{x}$ removal is estimated at $\$ 888 /$ ton and $\$ 1,161 /$ ton for constant and current dollar projections, respectively. If an $\mathrm{SO}_{2}$ credit is applied based on fuel sulfur reduction, the net levelized cost of $\mathrm{NO}_{x}$ removal is estimated at $\$ 766 /$ ton and $\$ 1,001 /$ ton for constant and current dollar projections, respectively.

Based on the levelized cost (in constant dollars) for reducing nitrogen oxides, excluding $\mathrm{SO}_{2}$ credits, the capital charge component made up around $27 \%$ of the total cost of $\mathrm{NO}_{x}$ reduction. The fixed operation and maintenance costs represented only $9 \%$, and the variable cost made up the $64 \%$ of the cost for removing $\mathrm{NO}_{\mathrm{x}}$. The variable operating cost is dominated by the differential price between natural gas and coal. 


\subsection{ECONOMICS}

This section provides the estimated costs of installation, operation and performance for commercial installation of GR-LNB on a $300 \mathrm{MW}_{\mathrm{e}}$ wall-fired boiler. The estimate is based on mature technology; i.e., a so-called "nth" plant which incorporates process improvements resulting from experience gained in earlier installations. The economics here, as opposed to those presented in the project "Performance and Economics Report" reflect the Second Generation GR technology wherein FGR is not required.

The capital and operating costs for the GR-LNB system for $\mathrm{NO}_{x}$ emissions reduction are based on a retrofit of a $300 \mathrm{MW}_{\mathrm{e}}$ wall-fired power plant. The degree of complexity regarding retrofit costs were factored based on the retrofit cost for the GR-LNB demonstration completed under this DOE contract.

\subsection{GR-LNB Economic Parameters}

The capital cost estimates presented summarize major equipment cost, approximate bulk material take-offs, and installation labor to arrive at direct construction costs. Construction indirects are added which include: field supervision, construction overhead and fee, and freight. In addition, costs for detailed engineering, project management, procurement, construction management, startup, and contingency are included to develop the total installed system cost.

All engineering and construction costs are representative of a turn-key contract arrangement. EER considers these estimates to be Class II, Preliminary Estimates. The estimates are expected to be representative of the actual cost $-15 \% /+30 \%$. This is based on the information available at this time which includes preliminary process design and conceptual engineering completed, recent major equipment quotes, bulk material takeoff's and average expected labor rates and productivity. 
This section provides the basis for the estimating procedures, along with a list of assumptions used for estimating installation man-hours and costs. The cost estimates have been developed using the following sources of information for equipment pricing and for the development of labor costs:

- Richardson's Rapid System 1993 edition of Process Plant Construction Estimating Standards

- Questimate Cost Estimating software by Icarus Corp.

- Means Electrical Cost Data 1991 edition

- Vendor Quotations for Major Equipment

- $\quad$ EER's database of previous equipment purchases

Data from all of these sources were summarized using EER cost estimating software. Once the direct costs were determined, costs for field supervision, contractor overhead and fee, freight, engineering, project management, construction management, start-up, and contingency were added to determine the total installed cost. Table 7-1 shows the cost parameters for developing the capital cost of the installed retrofit of the GR-LNB system on a $300 \mathrm{MW}_{\mathrm{e}}$ wall-fired unit. These values are commonly encountered in economic calculations and were used in recent studies of CCT processes by the U.S. Department of Energy. No changes were made to the parameters proposed by DOE.

\subsection{GR-LNB Capital Cost}

The design of the GR-LNB system included three integrated systems: 1) low $\mathrm{NO}_{x}$ burners, 2) natural gas injection and 3) OFA injection. It is further based on the Second Generation GR design wherein FGR is eliminated. Existing conventional burners are removed and replaced with low $\mathrm{NO}_{x}$ burners. A natural gas header was assumed to exist at the station and a tie-in was made to this supply header to provide the natural gas for the GR system. 


\section{TABLE 7-1. COST FACTORS}

\begin{tabular}{||l|c|c||}
\hline \multicolumn{1}{|c|}{ Item } & Units & Value \\
\hline Cost of debt & $\%$ & 8.5 \\
\hline Inflation rate & $\%$ & 4.0 \\
\hline Construction period & mos. & 9 \\
\hline Remaining life of power plant & - & 15 \\
\hline Year for cost presented in this report & - & 1996 \\
\hline Royalty allowance based on total process capital & $\%$ & 0.5 \\
\hline Capital charge factor - current dollars & - & 0.160 \\
\hline Capital charge factor - constant dollars & - & 0.124 \\
\hline O\&M cost levelization factor - current dollars & - & 1.314 \\
\hline O\&M cost levelization factor - constant dollars & - & 1.000 \\
\hline Power plant size & MW (net) & 300 \\
\hline Power plant type & Wall-fired & - \\
\hline Power plant capacity factor & $\%$ & 65 \\
\hline Property Taxes and Insurance & $\%$ & 3 \\
\hline Sales tax rate & $\%$ & 5.0 \\
\hline Cost of freight & $\%$ & 2.0 \\
\hline Engineering/home office fees of total process capital & $\%$ & 10.0 \\
\hline \hline
\end{tabular}

The tie-in pipe supplied gas to a control and metering station and from this station natural gas was distributed to gas injection nozzles located above the low $\mathrm{NO}_{\mathrm{x}}$ burners. The natural gas valve train, common to all of the injection nozzles, included flow metering and control equipment, and safety shut-off valves. 
OFA was assumed supplied from the existing hot secondary combustion air windbox. The existing windbox pressure on a wall-fired unit may not be adequate, so booster fans were assumed to be required. The installation of the natural gas injectors and OFA ports requires furnace tubewall modifications. There are no unusual boiler access hindrances that would inhibit normal installation of equipment. No asbestos removal is required during installation. The reburning system is assumed to be installed during a normally scheduled plant outage, negating downtown costs. A list of the major equipment associated with the GR-LNB retrofit in shown in Table 7-2. The sizes and quantities shown are for a standard $300 \mathrm{MW}_{\mathrm{e}}$ unit.

\section{TABLE 7-2. MAJOR EQUIPMENT LIST}

\begin{tabular}{|c|c|c|c|c|c|c|}
\hline \multirow{2}{*}{$\begin{array}{l}\text { Item } \\
\text { No. }\end{array}$} & \multirow[b]{2}{*}{ Item Name } & \multicolumn{2}{|c|}{ Number } & \multirow{2}{*}{$\begin{array}{c}\text { Unit } \\
\text { Capacity }\end{array}$} & \multirow{2}{*}{$\begin{array}{c}\text { Design } \\
\text { Conditions* }\end{array}$} & \multirow{2}{*}{$\begin{array}{c}\text { Material of } \\
\text { Construction }\end{array}$} \\
\hline & & In Use & Spare & & & \\
\hline 1 & Low NOx Burner & 30 & 0 & $\begin{array}{l}100 \times 10^{6} \\
\text { Btu/burner }\end{array}$ & & Steel \\
\hline $2 a$ & $\begin{array}{c}\text { Natural Gas } \\
\text { Delivery System }\end{array}$ & 1 & 0 & $\begin{array}{c}3,840 \mathrm{scfm} \\
60 \mathrm{psi}\end{array}$ & $\begin{array}{c}\text { National Electric Code } \\
\text { Class } 1 \text {, Division } 2\end{array}$ & Miscellaneous \\
\hline $2 b$ & Natural Gas Injector & 16 & 0 & $\begin{array}{l}240 \text { scfm/ } \\
\text { injector }\end{array}$ & & Steel \\
\hline $3 a$ & Overfire Air System & 1 & 0 & $200,000 \mathrm{scfm}$ & & Miscellaneous \\
\hline $3 b$ & $\begin{array}{l}\text { Overfire Air } \\
\text { Booster Fan }\end{array}$ & 1 & 0 & $200,000 \mathrm{scfm}$ & & \\
\hline $3 c$ & Overfire Air Injector & 8 & 0 & $\begin{array}{l}15,000 \mathrm{scfm} / \\
\text { injector }\end{array}$ & & Steel \\
\hline 4 & Control System & 1 & 0 & $\mathrm{n} / \mathrm{a}$ & & (Electronic) \\
\hline
\end{tabular}

Table 7-3 shows the major equipment costs. The total cost for the major equipment items of the GR-LNB system is $\$ 2.31$ million. This cost estimate is slightly less than the cost presented in the Performance And Economics Report. It assumes that the windbox pressure is adequate to provide cooling air to the natural gas injectors and the cost presented in the Performance and Economics Report includes the installation of a separate cooling fan. Table $7-4$ presents the overall capital cost for the GR-LNB system. This cost 
includes both equipment and installation costs. The total cost, including a $15 \%$ project contingency, is at $\$ 7.70$ million or $\$ 25.66 / \mathrm{kW}_{\mathrm{e}}$. The GR and LNB system capital costs can be easily separated from one another for they are independent systems. The capital cost for the GR system only is estimated at $\$ 3.54$ million or $\$ 11.79 / \mathrm{kW}_{\mathrm{e}}$, and the LNB system capital cost is estimated at $\$ 4.16$ million or $\$ 13.87 / \mathrm{kW}_{\mathrm{e}}$.

TABLE 7-3. MAJOR EQUIPMENT COST

\begin{tabular}{|c|c|c|c|c|c|c|}
\hline \multirow[b]{2}{*}{$\begin{array}{l}\text { Item } \\
\text { No. }\end{array}$} & \multirow[b]{2}{*}{$\begin{array}{l}\text { Item } \\
\text { Name }\end{array}$} & \multicolumn{3}{|c|}{ Cost/Unit } & \multirow[b]{2}{*}{$\begin{array}{l}\text { No. of } \\
\text { Units }\end{array}$} & \multirow[b]{2}{*}{$\begin{array}{c}\text { Total } \\
\text { Cost } \\
\$ 1,000 \text { s }\end{array}$} \\
\hline & & $\begin{array}{c}\text { F.O.B. } \\
\text { Equipment }\end{array}$ & $\begin{array}{c}\text { Sales } \\
\text { Tax } \\
(5 \%) \\
\end{array}$ & Total & & \\
\hline 1 & Low NOx Burners & 55.7 & 2.8 & 58.5 & 30 & $1,754.6$ \\
\hline 2 & $\begin{array}{c}\text { Natural Gas Injectors \& } \\
\text { Tubewall Penetrations }\end{array}$ & 5.1 & 0.3 & 5.4 & 8 & 42.8 \\
\hline $3 a$ & Overfire Air Booster Fan & 351.8 & 17.6 & 369.4 & 1 & 369.4 \\
\hline $3 b$ & $\begin{array}{l}\text { Overfire Air Injectors \& } \\
\text { Tubewall Penetrations }\end{array}$ & 17.4 & 0.9 & 18.3 & 8 & 146.2 \\
\hline & Total & 430.0 & 21.5 & 451.5 & 1 & $2,312.9$ \\
\hline
\end{tabular}

\subsection{GR-LNB Operating Cost}

EER conducted an analysis to evaluate the fixed and variable operating costs of a GR system, exclusive of fixed charges, for a $300 \mathrm{MW}_{\mathrm{e}}$ coal wall-fired unit (heat rate of 10,000 Btu/kWhr before GR-LNB); contributing cost factors were as follows:

1. Reburning Fuel Cost Differential Since gas costs more than coal on a heating value basis $\left(\$ / 10^{6} \mathrm{Btu}\right)$, there is a cost related to the amount of gas fired. This was calculated based on the delivered costs of gas and coal, the percentage of gas fired $\left(12.5 \%\right.$ of the total heat input). A value of $\$ 1.00 / 10^{6}$ Btu was used as the differential between the delivered price of natural gas $\left(\$ 2.47 / 10^{6} \mathrm{Btu}\right)$ and the delivered price of coal $\left(\$ 1.47 / 10^{6} \mathrm{Btu}\right)$. 
TABLE 7-4. GR-LNB CAPITAL COST

\section{Capital Cost}

\section{Category}

Equipment

Construction Labor

Construction Indirects

Other $(6 \%)$, Freight $(2 \%) \&$ Taxes $(5 \%)$

Gas Supply ${ }^{[1]}$

Gas Metering \& Reduction Station

Total Process Capital

Engineering (10\% of process capital)

Project Management (8\%) /Owners Costs (5\%)

Project Contingency @15\%

Total Plant Cost

Allowance for Funds During Construction ${ }^{[2]}$

Total Plant Investment (TPI)

Royalty Fees @ $0.5 \%$ of Total Process Capital

Startup Costs @ 3\% TPI

Working Capital @ 0.9\% TPI

Cost of Construction Downtime (28 days) ${ }^{[3]}$

Total Capital Requirement

\begin{tabular}{|c|c|}
\hline$\$ 10^{6}$ & $\$ / \mathrm{kWe}$ \\
\hline 2.46 & 8.20 \\
\hline 1.23 & 4.10 \\
\hline 0.76 & 2.53 \\
\hline 0.32 & 1.07 \\
\hline 0.00 & 0.00 \\
\hline 0.45 & 1.50 \\
\hline 5.22 & 17.40 \\
\hline 0.52 & 1.74 \\
\hline 0.68 & 2.26 \\
\hline 0.96 & 3.21 \\
\hline 7.38 & 24.61 \\
\hline 0.00 & 0.00 \\
\hline 7.38 & 24.61 \\
\hline 0.03 & 0.09 \\
\hline 0.22 & 0.74 \\
\hline 0.07 & 0.22 \\
\hline 0.00 & 0.00 \\
\hline 7.70 & 25.66 \\
\hline
\end{tabular}

[1] Gas supply availability at site assumed adequate

[2] No allowance included based on DOE guideline

[3] Assumed downtime to be during scheduled major outage 
2. Changes in Boiler Efficiency Since the boiler efficiency is lower when using gas as the reburning fuel there needs to be an increase in the amount of fuel fired. This increase was based upon the boiler efficiency loss $(0.80 \% \mathrm{w} / 12.5 \%$ gas) for $\mathrm{GR}$ and a composite fuel cost of $\$ 1.60 / 10^{6} \mathrm{Btu}$.

3. Auxiliary Power Since the GR fuel contributes a significant portion of the boiler fuel, there is a corresponding percentage decreased load on the coal pulverizers. However, there is added power required for the natural gas and OFA cooling air fans. The electricity cost was based on an auxiliary power cost of $\$ 0.02 / \mathrm{kWhr}$.

4. Operating Labor All reburning system operation is performed in the automatic control mode. Therefore, no additional plant operators are required.

5. Maintenance Items/Spare Parts An allowance of $2 \%$ of the total plant investment was used for total maintenance; $40 \%$ of the $2 \%$ was allocated for maintenance items and spare parts. Since the LNBs are replacement units, no additional maintenance cost is included for this equipment.

6. Maintenance Labor An allowance of $2 \%$ of the total plant investment was used for total maintenance; $60 \%$ of the $2 \%$ was allocated for maintenance labor. No additional labor is required to operate the GR-LNB system; however, additional maintenance is required due to the added equipment.

7. Administration and General Overhead An allowance of $60 \%$ of plant labor was added to cover administration and general overhead.

8. Local Property Taxes and Insurance An allowance of $3 \%$ of total plant investment was used to cover taxes and insurance.

The total annual incremental gross operating cost for the GR-LNB system, excluding fixed charges to payback capital, is estimated at $\$ 2.59$ million (see Table 7-5). If an $\mathrm{SO}_{2}$ allowance credit is taken based on the reduction of fuel sulfur when firing natural gas, the net operating cost is estimated at about $\$ 2.10$ million. This $\mathrm{SO}_{2}$ credit was based on an allowance of $\$ 95 /$ ton (Feb. 1996). Variable operating cost for the GR-LNB is about $\$ 2.26$ million and the fixed cost, excluding fixed charges, is about $\$ 0.33$ million. 


\section{TABLE 7:5 GR-LNB OPERATING COST}

\section{Annual Incremental Operating Costs ${ }^{[1]}$}

Annual Use

Variable Costs

Fuel:

Natural Gas

Supplemental Fuel

Utilities:

Electricity ${ }^{[4]}$

Ash Disposal Credit

Sub-Total

Fixed Costs

Labor: ${ }^{[5]}$

Maintenance ( $2 \%$ of GR TPI $\times 60 \%$ )

Supervision ( $20 \%$ of Maintenance Labor)

Supplies:

Maintenance ( $2 \%$ of GR TPI $\times 40 \%$ )

$\$ 1.00 / 10^{6} \mathrm{Btu}^{[2]}$

$\$ 1.60 / 10^{6} \mathrm{Btu}^{[3]}$

$\$ 2,135,250$

$136,65610^{6} \mathrm{Btu}$

(769) $10^{3} \mathrm{kWhr}$

$(8,541)$ tons

$\$ 20.00 / 10^{3} \mathrm{kWhr}$

$(\$ 15,374)$

$\$ 9.29$ /ton

$(\$ 79,346)$

$\$ 41,930$

$\$ 8,386$

Admin. and Gen. Ovhd. (60\% of total labor)

Local Taxes and Insurance @ $3 \%$ of TPI

$\$ 221,486$

Sub-Total

$\$ 329,944$

Total Gross Operating Cost

$\$ 2,588,441$

SO2 Allowance @ \$95/ton ${ }^{[6]}$

$(\$ 486,336)$

Total Net Operating Cost

$\$ 2,102,105$

[1] 65\% Capacity factor @ 300 MWe net capacity $(10,000 \mathrm{Btu} / \mathrm{kWhr}$ heat rate) w/ 12.5\% fuel heat input as natural gas

[2] Natural gas assumed delivered at \$2.47/MM Btu; coal cost at \$1.47/MM Btu

[3] Extra fuel added to make up for loss in efficiency $(0.80 \%)$ at same coal/gas ratio as reburn

[4] OFA booster fan power requirement ( $480 \mathrm{kWhr} @ 65 \%$ capacity), less pulverizer credit of $10 \mathrm{kWhr} / \mathrm{ton}$ coal

[5] Assumed no added operating labor. No incremental maintenance costs for LNBs since they are repalcement parts

[6] February 1996 Allowance Credit Value, reduction based on $4.8 \mathrm{lb} \mathrm{SO} 2 / \mathrm{MM}$ Btu for coal w/coal reduction of $12.5 \%$ 


\subsection{Summary of Performance and Economics}

Based on the developed capital and fixed/variable operating costs, economic projections were made using current dollars which include an inflation rate of $4.0 \%$, and constant dollars which ignore inflation. The factors used in the development of the technology economics are shown in Table 7-1.

Table 7-6 shows the performance and cost for a $300 \mathrm{MW}_{\mathrm{e}}$ GR-LNB System that is retrofitted to a wall-fired boiler. The table reflects the $\mathrm{NO}_{x}$ reduction (64\% or 3,990 TPY) costs based on a $65 \%$ capacity factor for the unit with $12.5 \%$ of the heat input supplied by natural gas at a gas to coal price differential of $\$ 1.00 /$ million Btu. The incremental increase in the levelized cost of power, including capital charges is estimated at 2.07 mills $/ \mathrm{kWhr}$ in constant dollars and $2.71 \mathrm{mills} / \mathrm{kWhr}$ in current dollars.

If an $\mathrm{SO}_{2}$ credit is applied based on fuel sulfur reduction when firing natural gas, the net incremental increase in the levelized cost of power is estimated at $1.79 \mathrm{mills} / \mathrm{kWhr}$ in constant dollars and 2.34 mills $/ \mathrm{kWhr}$ in current dollars. The levelized cost of $\mathrm{NO}_{x}$ removal is estimated at $\$ 888 /$ ton and $\$ 1,161 /$ ton for constant and current dollar projections, respectively. If an $\mathrm{SO}_{2}$ credit is applied based on fuel sulfur reduction, the net levelized cost of $\mathrm{NO}_{x}$ removal is estimated at $\$ 766 /$ ton and $\$ 1,001 /$ ton for constant and current dollar projections, respectively.

Based on the levelized cost (in constant dollars) for reducing nitrogen oxides, excluding $\mathrm{SO}_{2}$ credits, the capital charge component made up around $27 \%$ of the total cost of $\mathrm{NO}_{x}$ reduction. The fixed operation and maintenance costs represented only $9 \%$, and the variable cost made up the $64 \%$ of the cost for removing $\mathrm{NO}_{\mathrm{x}}$. The variable operating cost is dominated by the differential price between natural gas and coal. 
TABLE 7-6. GR-LNB ECONOMICS AND PERFORMANCE SUMMARY

\section{Summary of Data}

\section{Power Plant Attributes}

Plant capacity, net

Power produced, net

Capacity factor

Plant life

Coal feed

Sulfur in coal

$$
\begin{gathered}
\text { Units } \\
\text { MWe } \\
10^{9} \mathrm{kWh} / \mathrm{yr} \\
\% \\
\mathrm{yr} \\
10^{6} \text { tons/yr } \\
\text { wt } \%
\end{gathered}
$$

Emissions Control Data

Removal efficiency

Emissions standard (EPA 40CFR Part 76 - 12/19/96)

Emissions without controls

Emissions with controls

Amount reduced

\section{Units}

$\%$

$\mathrm{Ib} / 10^{6} \mathrm{Btu}$

$\mathrm{lb} / 10^{6} \mathrm{Btu}$

$\mathrm{lb} / 10^{6} \mathrm{Btu}$

tons/yr
Value

300

1.71

65

15

683,280

3.0

Value

64

0.46

0.73

0.26

3,990

Levelized Cost of Power

Current Dollars

$\begin{array}{cc}\text { Factor } & \text { Mills } / \mathrm{kWhr} \\ 0.160 & 0.72 \\ 1.314 & 0.25 \\ 1.314 & 1.74 \\ & 2.71 \\ 1.314 & (0.37) \\ & 234\end{array}$

Constant Dollars

Capital Charge

2.34

Factor

0.124

Mills/kWhr

Fixed O\&M Cost

Variable Operating Cost

Total Cost

$\mathrm{SO}_{2}$ Credits

Total Cost $w / \mathrm{SO}_{2}$ Credits

Levelized Cost--NOx Basis

Current Dollars

\$/ton

Factor Removed

1.000

0.56

0.19

1.000

1.32

2.07

1.000

1.79

0.160

309

109

744

1,161

(160)

1,001

Constant Dollars

$\$ /$ ton

Factor

0.124

Removed

239

1.000

83

1.314

1.000

566

888

1.314

1.000

(122)

766

Basis: $64 \%$ NOx reduction based on unit with 0.5 seconds reburn zone residence time 


\section{5}

Effect of Variables on Economics

The economics developed for the $300 \mathrm{MW}_{\mathrm{e}}$ system were used to determine the economic effects of varying the selected parameters shown below:

- Fuel cost differential between gas and coal

- Wall-fired unit size

- Onstream capacity factor

- Sulfur dioxide allowance credits

The GR-LNB capital costs developed for a range of power plant sizes was based on scaling the power plant cost based on a 0.75 power factor. The effects of the above variables, including an annual $12.4 \%$ fixed charge rate, are shown In Figures $7-1$ through 7-4. $\mathrm{NO}_{x}$ reduction costs are based on constant dollars and include $\mathrm{SO}_{2}$ allowance credits. Of the four parameters that were varied, clearly the price of natural gas is the most dominant parameter regarding the cost of $\mathrm{NO}_{x}$ emission reductions.

Figure 7-1 Effect of plant size The size of plant on economics becomes less significant for unit sizes of $300 \mathrm{MW}_{\mathrm{e}}$ and greater. For example, the cost of $\mathrm{NO}_{\mathrm{x}}$ emissions for a 300 $\mathrm{MW}_{\mathrm{e}}$ unit is $\$ 118 /$ ton less than a $150 \mathrm{MW}_{\mathrm{e}}$ plant and when increasing the size to $450 \mathrm{MW}_{\mathrm{e}}$ the cost is reduced only $\$ 56 /$ ton.

Figure 7-2 Effect of capacity factor The onstream capacity factor impact is linear. For example, the cost of $\mathrm{NO}_{\mathrm{x}}$ emissions for a $55 \%$ capacity factor is $\$ 37 /$ ton more than that for $65 \%$ and when it increases from $65 \%$ to $75 \%$ the cost is reduced $\$ 33 /$ ton. These two values are not identical; linearity occurs with the ratio of the two capacity factors.

Figure 7-3 Effect of gas to coal price differential The price of natural gas has a linear effect on the $\mathrm{NO}_{x}$ reduction costs. For every $\$ 0.25 / 10^{6} \mathrm{Btu}$ change, either an increase or decrease in the gas to coal price differential, there is a corresponding $\$ 253 /$ ton cost effect.

Figure 7-4 Effect of $\mathrm{SO}_{2}$ allowance price The price of $\mathrm{SO}_{2}$ allowances also has a linear effect on the $\mathrm{NO}_{x}$ reduction costs. For every $\$ 50 /$ ton change, either an increase or decrease in price, there is a corresponding $\$ 64 /$ ton effect. 


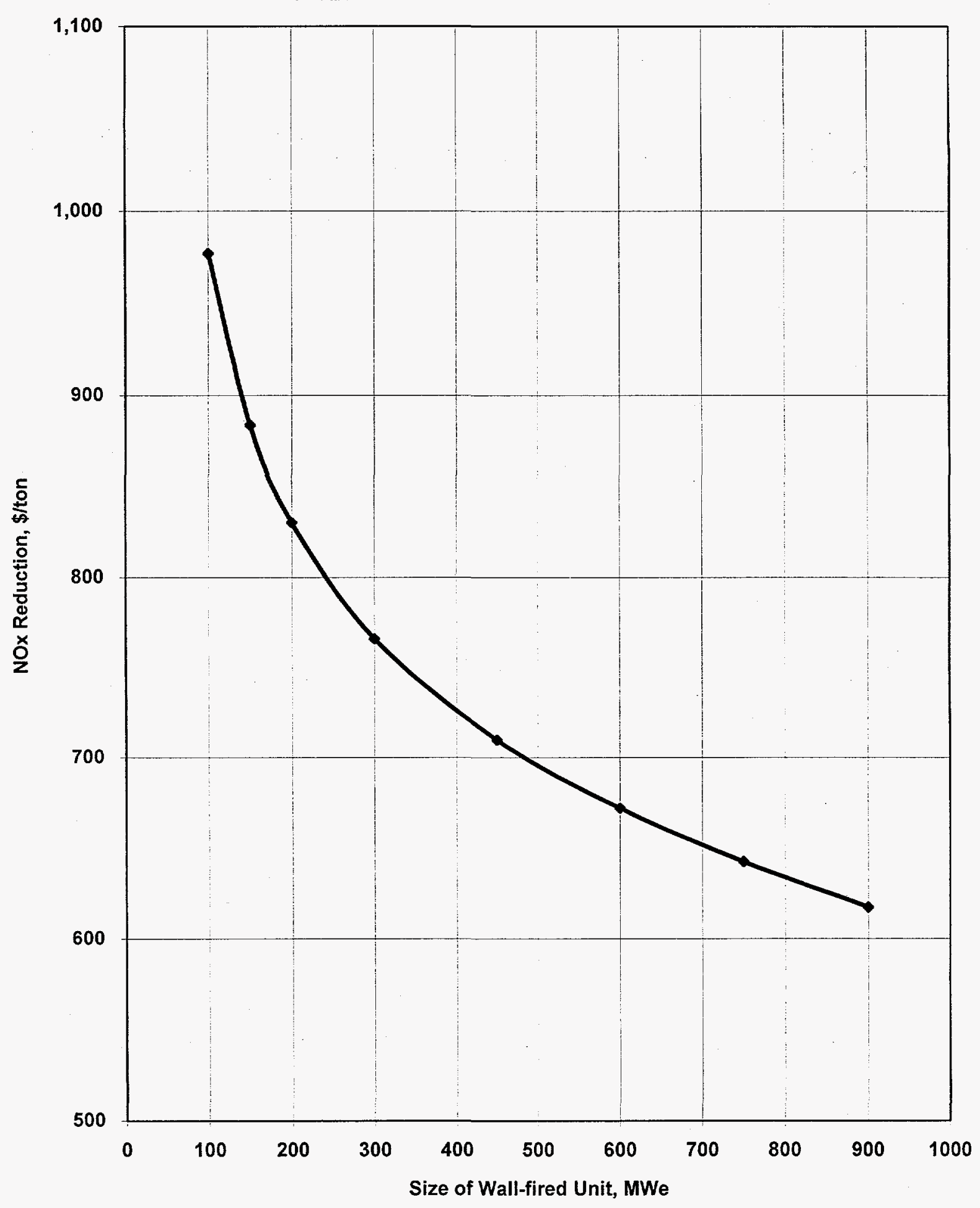

Figure 7-1. The effect of unit size on the cost of $\mathrm{NO}_{x}$ reduction 


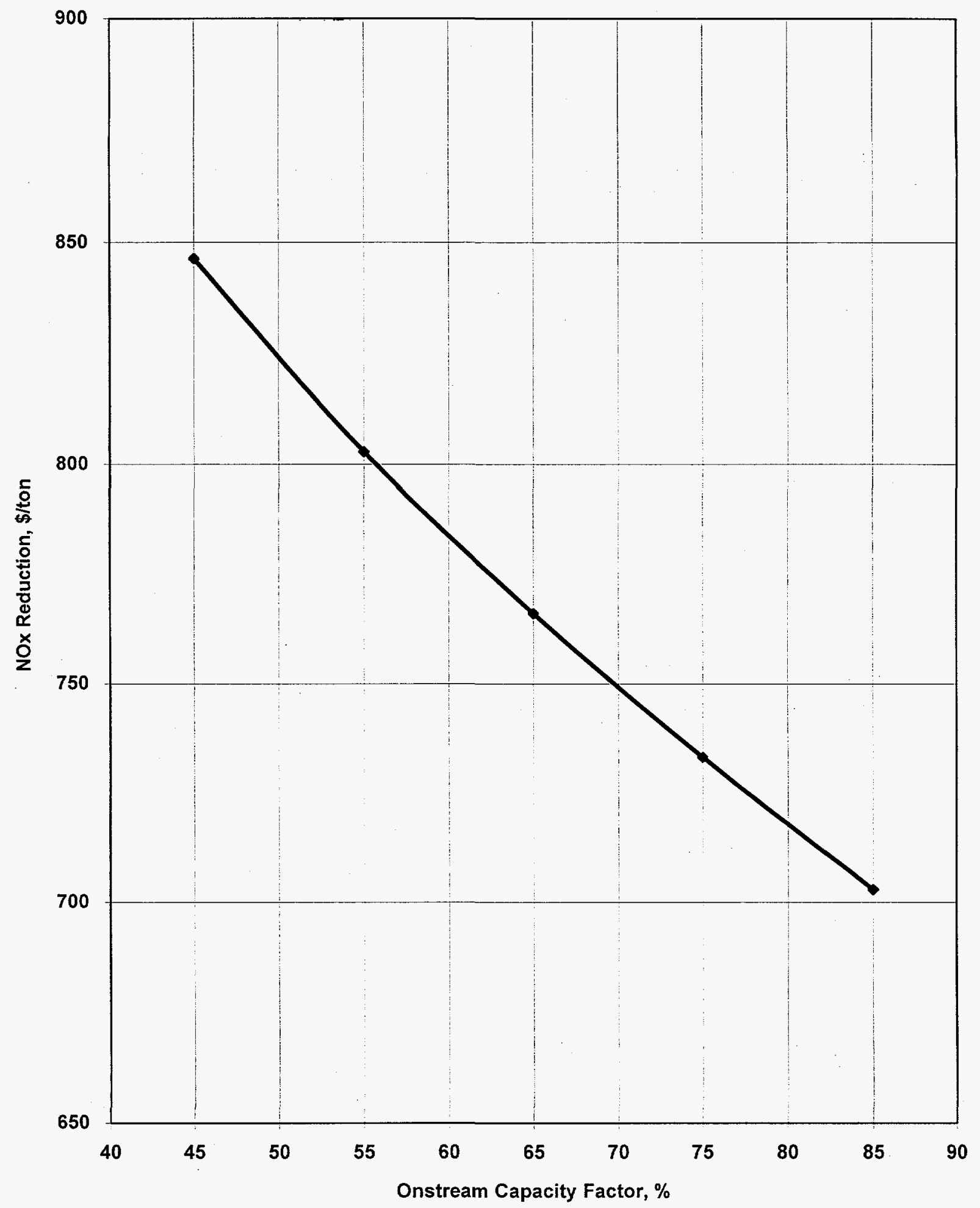

Figure 7-2. The effect of capacity factor on the cost of $\mathrm{NO}_{x}$ reduction 


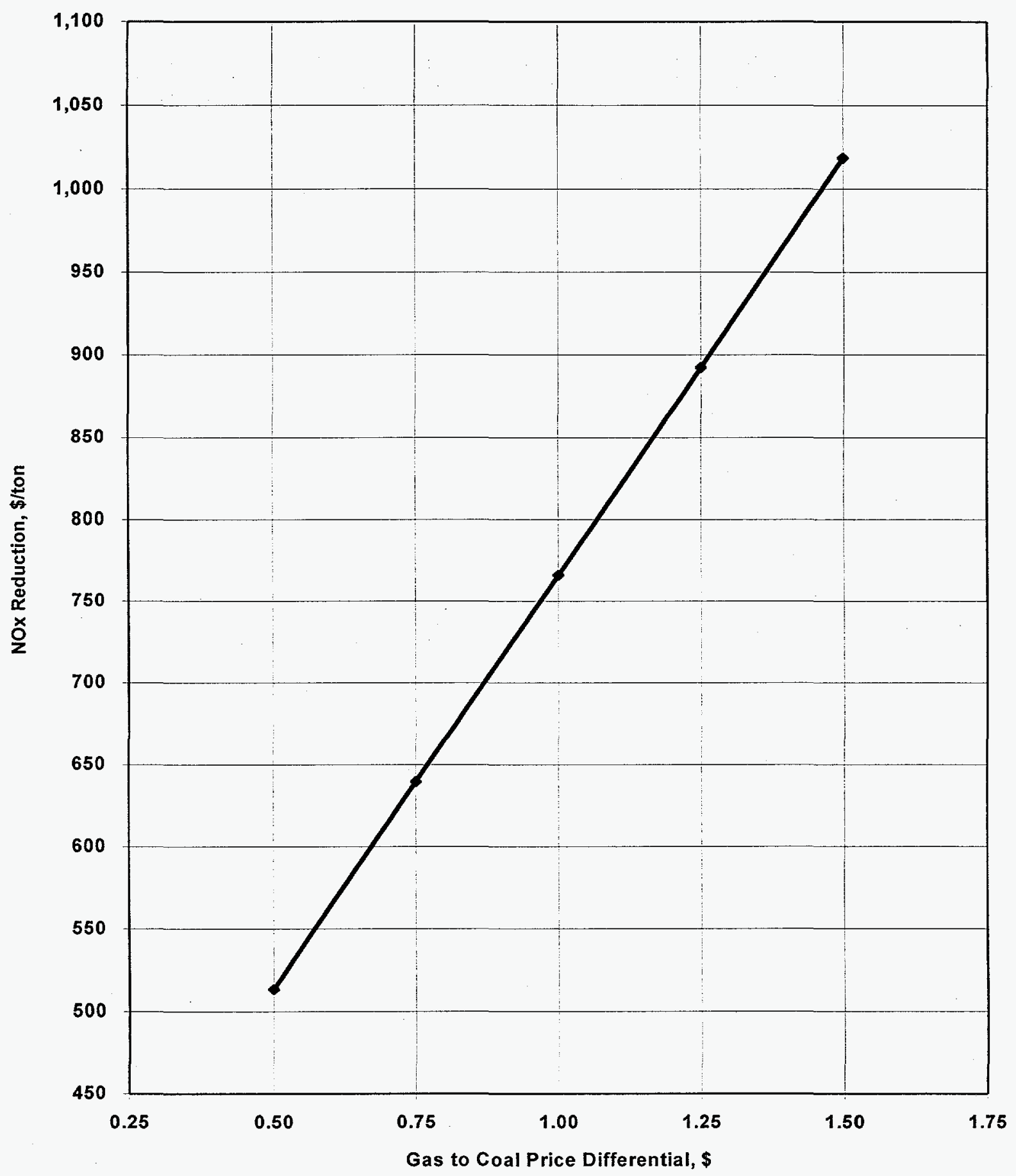

Figure 7-3. The effect of gas to coal price differential on the cost of $\mathrm{NO}_{\mathrm{x}}$ reduction $7-14$ 


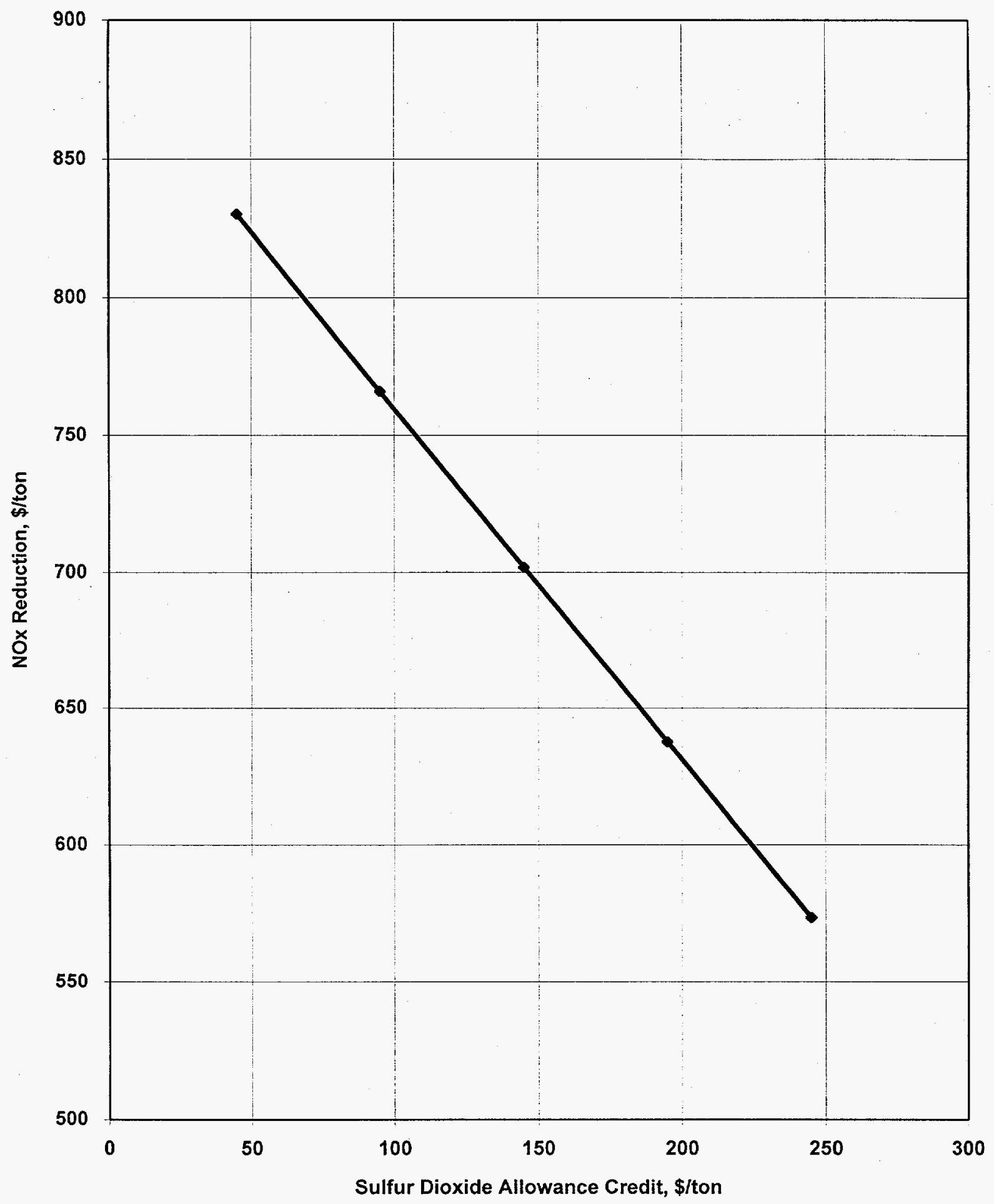

Figure 7-4. The effect of $\mathrm{SO}_{2}$ allowance price on the cost of $\mathrm{NO}_{\mathrm{x}}$ reduction 


\subsection{GR - LNB Comparison with other $\mathrm{NO}_{x}$ Control Technologies}

Methods for controlling $\mathrm{NO}_{\mathrm{x}}$ from coal-fired utility boilers include combustion modifications and post combustion treatment of the flue gas. Combustion modifications involve operating the primary combustion zone under fuel rich conditions (and therefore reduced temperatures), cooling the flame at a higher rate, and dilution of the flame to reduce adiabatic flame temperatures. Gas residence times in the high temperature zone as well as excess air levels are reduced, inhibiting the formation of fuel and thermal $\mathrm{NO}_{\mathrm{x}}$.

The combustion modification technique that can be applied depends on the type of boiler and method of firing the fuel. Low $\mathrm{NO}_{x}$ burner technology with OFA has been successfully applied to wall and tangentially fired pulverized coal units. Low $\mathrm{NO}_{x}$ burner technology, however, cannot be applied to cyclone units due to the configuration of the cyclone furnaces.

The importance of OFA as it relates to staging the combustion process has been determined in testing of low $\mathrm{NO}_{x}$ burner retrofits and demonstrations. This information has promoted the addition of OFA to conventional firing systems as a stand alone alternative to low $\mathrm{NO}_{\mathrm{x}}$ burners for utilities requiring moderate reductions.

OFA systems may be "close-coupled" to the existing burner assemblies on tangentially fired units, or separated higher into the furnace on both tangentially and wall fired designs for deeper staging and increased $\mathrm{NO}_{x}$ reductions. Staged combustion with OFA also cannot be applied to cyclone-fired units with high sulfur coal feedstocks. Industry experience indicates that this combustion modification technique for high sulfur feedstocks results in high levels of corrosion in the cyclone barrels. 
Post combustion techniques include reburning with all types of fuels, selective catalytic reduction (SCR), and selective non-catalytic reduction (SNCR). GR is described elsewhere in this manual. Coal and coal water slurry (CWS) have also been proposed as reburning fuels. In Table 7-7 below, a relative comparison is made between the cost, design, and operating factors associated with the three reburning fuels.

TABLE 7-7. REBURNING FUEL COMPARISON

\begin{tabular}{|c|c|c|c||}
\hline & Natural Gas & Coal & CWS \\
\hline Reburning Fuel Cost & Highest & None & Low \\
\hline Capital Cost & Lowest & Highest & Low \\
\hline $\mathrm{SO}_{2}$ Reduction & Yes & None & Varies \\
\hline Injector Size & Small & Large & Small \\
\hline Auxiliary Power & Low & High & Moderate \\
\hline Residence Time Requirement & Low & Moderate & Moderate \\
\hline
\end{tabular}

Natural gas is the most expensive reburning fuel, with the differential above coal averaging $\$ 1.00$ to $\$ 1.50 / 10^{6} \mathrm{Btu}$. Coal reburning involves no differential fuel cost since the total heat input to the unit does not change. The cost of CWS is site specific depending on the cost and the availability of the coal fines used to formulate the slurry.

CWS may be produced by wet milling the primary coal ( $\$ 4 /$ ton), using the minus 100 mesh froth cell product from coal cleaning plants, or recovering coal fines from coal preparation plant ponds with advanced coal cleaning techniques (delivered cost could be less than primary coal cost or higher depending on ownership of resource, quality of impounded coal and distance from power plant). Other fuels, like fuel oil and Orimulsion ${ }^{\circledR}$ (a Venezuelan bitumen-water emulsion) can also be used as effective reburning fuels. 
If gas is available at the power plant, GR offers the lowest capital cost investment since there are no fuel preparation or handling equipment requirements. Coal reburning will require the addition of coal handling and milling equipment, milling equipment upgrading, or storage and handling equipment for coal fines produced elsewhere. Reburning with slurry requires CWS feeding equipment, added air compression for CWS atomization, and either onsite CWS storage or CWS formulation equipment for the delivered coal fines.

Since natural gas contains no sulfur, GR offers an additional $\mathrm{SO}_{2}$ reduction over that provided by $\mathrm{SI}$ or other processes since gas replaces coal containing sulfur. For normal GR applications gas would replace coal and $\mathrm{SO}_{2}$ emissions would be reduced some $20 \%$.

Auxiliary power requirements for GR are relatively lower since fuel handling and preparation equipment is not necessary as it is with reburning using coal or CWS as the reburn fuels. Demonstrations of GR with FGR have shown that, with most furnace designs and adequate natural gas pressures available, the FGR may not be necessary to promote adequate mixing of the natural gas with the furnace gases. In such a case, the FGR fan can be eliminated, further reducing the auxiliary power requirements.

Consideration of the furnace geometry and available residence time may be critical in the selection of the reburning fuel. Natural gas requires the shortest residence time for the reburning process since the fuel "particle" size is at the molecular level. Coal, having larger particle sizes will require longer residence times.

Selective catalytic (SCR) and non-catalytic (SNCR) reduction are post combustion treatment methods. In the SCR process, ammonia vapor and preheated air are mixed and injected into the flue gas at the boiler exit. The optimum temperature window for this process is 550 to $750^{\circ} \mathrm{F}$. Flue gas at this temperature is generally available upstream of the unit's air heater. A catalytic converter is installed in the duct work at this location. $\mathrm{NO}_{\mathbf{x}}$ is reduced by the process to diatomic nitrogen in the converter. SCR systems are better 
suited for installation downstream of a hot side precipitator since dust buildup and catalyst fouling are reduced. On systems installed upstream of a cold side precipitator, the catalyst mesh size must be increased to reduce dust build-up and catalyst fouling. The larger mesh size dictates a larger converter to provide the necessary surface area.

Ammonia slip (unreacted $\mathrm{NH}_{3}$ ) is a major operating consideration with SCR systems. As the catalyst is expended, ammonia slip increases. Ammonia passing through the converter forms ammonium sulfate in particulate form which may foul equipment downstream such as air heaters, draft fans, or precipitators. Sulfates may also form in the catalyst pores to deactivate the catalyst if the flue gas temperature drops below $500^{\circ} \mathrm{F}$. Unreacted ammonia may also be adsorbed by the fly ash and increase the leachability of metals in the ash, affecting the salability of the fly ash.

In the SNCR process, ammonia or urea based reagents are injected into the upper furnace at locations where flue gas temperatures range from 1600 to $2000^{\circ} \mathrm{F}$. With this process the required high activation energy is provided by the temperature of the flue gas, and a converter with catalyst is not necessary.

An independent study completed for the U.S. EPA (Contract No. 68-D2-0168) "Investigation of Performance and Cost of $\mathrm{NO}_{x}$ Controls as Applied to Group 2 Boilers", compared the costs of competing $\mathrm{NO}_{x}$ control technologies. The costs for the SNCR and SCR systems were based on the above study for cyclone-fired units. The costs of SNCR and SCR should not be boiler type dependent although costs will vary based on site specific factors. The bases for the GR, GR-LNB, LNB and Coal Reburning systems were developed by EER. In Table 7-8, the cost of Gas Reburning, Coal Reburning, SNCR and SCR, based on $\$ / k W_{e}$ and $\$ /$ ton of $\mathrm{NO}_{x}$ removed are shown for $300 \mathrm{MW}_{\mathrm{e}}$ wall-fired units. The $\mathrm{NO}_{\mathrm{x}}$ reduction costs are based on incremental annual operating costs that include a $12.4 \%$ fixed charge rate on total plant investment to cover investment related costs. 
TABLE 7-8. $300 \mathrm{MW}_{\mathrm{e}}$-WALL-FIRED NO ${ }_{x}$ CONTROL COMPARISON

\begin{tabular}{||l|c|c|c||}
\hline \multicolumn{1}{|c|}{ Technology } & $\begin{array}{c}\mathrm{NO}_{\mathrm{x}} \text { Reduced } \\
\%\end{array}$ & $\begin{array}{c}\text { Capital Cost } \\
\$ / \mathrm{kW}_{\mathrm{e}}\end{array}$ & $\begin{array}{c}\mathrm{NO}_{\mathrm{x}} \text { Removed }^{5} \\
\$ / \text { ton }\end{array}$ \\
\hline Gas Reburning ${ }^{1}$ (GR only) & 60 & 11.8 & $527^{6}$ \\
\hline Low NO ${ }_{\times}$Burners (LNBs only) & 45 & 13.9 & 227 \\
\hline $\mathrm{GR}^{1}$-LNB (2nd Generation) & 64 & 24.6 & $766^{6}$ \\
\hline Coal Reburning $^{2}$ & 50 & 28.0 & 592 \\
\hline $\mathrm{SNCR}^{3}$ & 35 & 9.0 & 700 \\
\hline $\mathrm{SCR}^{4}$ & 50 & 44 & 575 \\
\hline
\end{tabular}

(1) Natural Gas @ $\$ 2.47 / 10^{6}$ Btu and Coal @ $\$ 1.47 / 10^{6}$ Btu

(2) No added pulverizer requirement

(3) 50\% Urea solution @ \$0.75/gal

(4) Anhydrous Ammonia @ \$162/ton \& SCR catalyst replacement (3 yr life) @ \$350/ft

(5) Base levelized costs using current dollars

(6) Includes a $\$ 95 /$ ton $\mathrm{SO}_{2}$ allowance credit

As shown in the table, the $\mathrm{NO}_{x}$ control technologies show a cost per ton of $\mathrm{NO}_{x}$ removed that ranges from approximately $\$ 230$ to $\$ 770$. Based on this comparison low $\mathrm{NO}_{x}$ burners are the least expensive. SNCR and GR-LNB are the most expensive. GR, coal reburning and SCR are similar when with $G R$, the price differential between the gas and the primary coal is $\$ 1.00 / 10^{6} \mathrm{Btu}$.

The $\mathrm{NO}_{\mathrm{x}}$ reduction for SCR assumed in the mentioned study was low, only $50 \%$. However, SCR systems have achieved $80 \%+$ reductions with increased catalyst volume. For $\mathrm{NO}_{x}$ reduction beyond what is possible by a particular technology, it is possible to combine some technologies for deeper reduction. For an example, Advanced GR is currently being marketed involving the simultaneous application of GR and SNCR. Overall $\mathrm{NO}_{x}$ reduction is expected to be in the range of 75 to 90 percent. 


\section{REFERENCES}

1. Reed, R. D., "Process for Disposal of Nitrogen Oxide." John Zink Company, U.S. Patent 1274637, 1969.

2. Takahashi, Y., et al., "Development of Mitsubishi 'MACT' In-Furnace $\mathrm{NO}_{\times}$Removal Process." Presented at the U.S.-Japan $\mathrm{NO}_{x}$ Information Exchange, Tokyo, Japan, May 25-30, 1981. Published in Mitsubishi Heavy Industries, Ltd. Technical Review, Vol. 18 , No. 2.

3. Chen, S. L., M. P. Heap, and D. W. Pershing, The Nineteenth Symposium (International) on Combustion, the Combustion Institute, 1983.

4. Greene, S. B., S. L. Chen, D. W. Pershing, M. P. Heap, and W. R. Seeker, "Bench Scale Process Evaluation of Reburning for In-Furnace $\mathrm{NO}_{\mathrm{x}}$ Reduction," ASME Transactions Journal of Engineering for Gas Turbines and Power, 1985.

5. McCarthy, J. M., B. J. Overmore, S. L. Chen, W. R. Seeker, and D. W. Pershing, "Pilot Scale Process Evaluation of Reburning for In-Furnace $\mathrm{NO}_{x}$ Reduction," Final Report, EPA Contracts 68-02-3925 and 68-02-3955 Work Assignment No. 10, 1985.

6. U.S. Department of Energy. Office of Fossil Energy. "Enhancing the Use of Coals by Gas Reburning and Sorbent Injection; A Project Proposed by Energy and Environmental Research Corporation." Washington, D.C.: Government Printing Office, May 1987. DOE/FE-0087 CCT/87 PC 79796.

7. Energy and Environmental Research Corporation, "Enhancing the Use of Coals by Gas Reburning and Sorbent Injection," Comprehensive Report to Congress, Clean Coal Technology Demonstration Program, A Project Proposed by Energy and Environmental Research Corporation to the U.S. Department of Energy, Office of Fossil Energy, May, 1987.

8. Bartok, W. and Folsom, B. A., "Control of $\mathrm{NO}_{x}$ and $\mathrm{SO}_{2}$ Emissions by Gas Reburning-Sorbent Injection," presented at the American Institute of Chemical Engineers Annual Meeting, New York, New York, November 1987.

9. Payne, R., et. al., "Demonstration of Gas Reburning-Sorbent Injection $\mathrm{NO}_{x} / \mathrm{SO}_{2}$ Control Technology on Three Utility Boilers," presented at the American Institute of Chemical Engineers 1988 Summer National Meeting, Denver, Colorado, August 2124, 1988. 
10. England, G. C., et. al., "Prototype Evaluation of Sorbent Injection on a Tangentially Fired Utility Boiler," presented at the 1990 Joint EPAVEPRI SO ${ }_{2}$ Control Symposium, New Orleans, Louisiana, May 8-11, 1990.

11. Folsom, B. A. and Bartok, W., "Gas Reburning-Sorbent Injection for the Control of Acid Rain Precursors from Coal Fired Utility Boilers," presented at the ASTM Symposium on Innovations and Uses for Lime, San Francisco, California, June 19, 1990.

12. Wu, K. T., et. al., "Development and Application of a Gas Reburning Process Model for the Design of Boiler $\mathrm{NO}_{x}$ Reductions," presented at the 1991 International Joint Power Generation Conference, San Diego, California, October 1991.

13. Borio, R. W., et. al., "Reburn Technology for $\mathrm{NO}_{x}$ Control on a Cyclone-Fired Boiler; an Update," presented at the 1991 International Joint Power Generation Conference \& Exposition, San Diego, California, October 6-10, 1991.

14. Opatrny, J. C., Folsom, B. A., Keen, R. T., Nguyen, Q. H., Payne R., and Sommer, T. M., "Operating Experience with a Gas Reburning-Sorbent Injection System for Acid Rain Precursor Emission Control for Utility Boilers," presented at the International Power Generation Conference, San Diego, California, October 6-10, 1991.

15. Angello, L. C., et. al., "Field Evaluation of Gas Reburning for Combined $\mathrm{NO}_{x}$ and $\mathrm{SO}_{2}$ Emission Control on Utility Boilers," presented at the 9th World Clean Air Congress \& Exhibition in Montreal, Quebec, August 30-September 4, 1992.

16. Angello, L. C., Engelhardt, D. A., Folsom, B. A., Opatrny, J. C., Sommer, T. M., and Ritz, H. J., "Gas Reburning-Sorbent Injection Demonstration Results," presented at the U.S. Department of Energy First Annual Clean Coal Technology Conference, Cleveland, Ohio (September 22-23, 1992).

17. Engelhardt, D. A., Rooney, H. V., Payne R., and Ritz, H. J., "Gas ReburningSorbent Injection for Acid Rain Precursor Emission Control--Addressing Retrofit Considerations," presented at the International Power Generation Conference, Atlanta, Georgia, October 18-22, 1992.

18. Sanyal, A., et. al., "Cost Effective Technologies for $\mathrm{SO}_{2}$ and $\mathrm{NO}_{\times}$Control," presented at Power-Gen '92, Orlando, Florida, November 17-19, 1992.

19. England, G. C., D. K. Moyeda, Q. Nguyen, and B.A. Folsom, "Prototype Evaluation of Limestone Injection Multistage Burner (LIMB) Technology on a Pulverized-CoalFired Boiler," EPRI TR-101072, Volumes 1 - 5, Project 2786-02, February, 1993. 
20. Folsom, B. A., et. al., "Reducing Stack Emissions by Gas Firing in Coal-Designed Boilers--Field Evaluation Results," presented at the EPRI/EPA 1993 Joint Symposium on Stationary Combustion $\mathrm{NO}_{x}$ Control, Miami Beach, Florida, May 2427, 1993.

21. Keen, R. T., et. al., "Gas Reburning-Sorbent Injection Demonstration Results," presented at the 1993 EPRI/EPA/DOE $\mathrm{SO}_{2}$ Control Symposium, Boston, Massachusetts, August 24-27, 1993.

22. Clean Coal Technology Topical Report Number 3 , Revision 1, "Reduction of $\mathrm{NO}_{\mathrm{x}}$ and $\mathrm{SO}_{2}$ Using Gas Reburning, Sorbent Injection and Integrated Technologies," September 1993.

23. Keen, R. T., Hong, C. C., Opatrny, J. C., Sommer, T. M., Folsom, B. A., Payne, R., Ritz, H. J., Pratapas, J. M., May, T. J., and Krueger, M. S., "Enhancing the Use of Coal by Gas Reburning and Sorbent Injection," presented at the Second Annual Clean Coal Technology Conference, Atlanta, Georgia, September 7-9, 1993.

24. Sanyal, A., Sommer, T. M., Hong, C. C., Folsom, B. A., Payne R., Seeker, W. R., and Ritz, H. J., "Advanced $\mathrm{NO}_{x}$ Control Technologies," presented at the Tenth Annual International Pittsburgh Coal Conference, September 20-24, 1993.

25. Pont, J., et. al., "Glass Tank NO Emission Control with Gas Reburn," GRI Report No. GRI-94/0018.2, March, 1994.

26. Sanyal, A., et. al., "Gas Reburning for $\mathrm{NO}_{x}$ Reduction--An Integrable Cost Effective Technology for International Applications," presented at the Clean Fuel Technology Conference, London, UK, May 19, 1994.

27. Keen, R. T., Light, M. E., Engelhardt, D. A., Beshai, R. Z., Sommer, T. M., Folsom, B. A., Ritz, H. J., Pratapas, J. M., May, T. J., Rindahl, E. G., and Booker, T., "Gas Reburning in Tangentially-, Wall-, and Cyclone Boilers--An Introduction to SecondGeneration Gas Reburning," presented at the Third Annual Clean Coal Technology Conference, Chicago, Illinois, September 6-8, 1994.

28. Keen, R. T., Light, M. E., Opatrny, J. C., Sommer, T. M., and Folsom, B. A., Marquez, A. M., Payne, R., and Ritz, H. J., "Demonstration of Gas ReburningSorbent Injection on a Cyclone-Fired Boiler," presented at the Third Annual Clean Coal Technology Conference, Chicago, Illinois, September 6-8, 1994.

29. Moyeda, D. K., et. al., "Application of Gas Reburning Technology to Glass Furnaces for $\mathrm{NO}_{x}$ Emission Control," presented at the AFRC/JFRC Pacific Rim International Conference on Environmental Control of Combustion Processes, Maui, Hawaii, October 16-20, 1994. 
30. Folsom, B. A., Sommer, T. M., Ritz, H. J., Pratapas, J., Bautista, P., and Facchiano, T., "Three Gas Reburning Field Evaluations: Final Results and Long Term Performance," presented at the $1995 \mathrm{NO}_{\mathrm{x}}$ Symposium.

31. Morrison, D. K., et. al., "Coal Water Slurry Reburning for $\mathrm{NO}_{x}$ Emissions Control," presented at the 20th International Technical Conference on Coal Utilization \& Fuel Systems, Clearwater, FL, March 20-23, 1995.

32. Ashworth, R. A., et. al., "Reburning for Utility Boiler NOx Control - A Comparison of Theory and Practice," presented at the ASME 1996 International Joint Power Generation Conference, Houston, TX, October 13-16, 1996.

33. "Investigation of Performance and Cost of NOx Controls as Applied to Group 2 Boilers", prepared for the U.S. EPA by the Cadmus Group, Bechtel Power Corporation and SAIC, EPA Contract No. 68-D2-0168, Work Assignment No. 3C08, July, 1995. 


\section{BIBLIOGRAPHY OF PRIOR REPORTS ON THIS CCT-3 GR-LNB PROJECT (DOE Cooperative Agreement No. DE-FC22-91PC90547)}

Environmental Monitoring Plan, October 1991.

Public Design Report, April 1992.

Baseline Test Report, June 1992.

Phase III Test Plan, September 1992.

Results of Environmental Monitoring Testing, March 1993.

Environmental Monitoring Report, Optimization Testing Period, June 1995.

Environmental Monitoring Report, Long-Term Testing Period, June 1995.

Environmental Monitoring Plan, July 1993.

Performance and Economics Report, September, 1998.

\section{BIBLIOGRAPHY OF PREVIOUS CCT-1 GR-SI PROJECTS}

"Volume 1 - Summary, Phase I - Design and Permitting, Tangentially Fired Host Site, Illinois Power Company, Hennepin Station Unit 1", Prepared under U.S. DOE Cooperative Agreement, DE-FC22-87PC79796, Gas Research Institute Contract No. 5087-254-149, State of Illinois Coal and Energy Development Agreement, March 1989.

"Volume 2 - Baseline Test Report, Phase I - Design and Permitting, Tangentially Fired Host Site, Illinois Power Company, Hennepin Station Unit 1", Prepared under U.S. DOE Cooperative Agreement, DE-FC22-87PC79796, Gas Research Institute Contract No. 5087254-149, State of Illinois Coal and Energy Development Agreement, March 1989.

"Volume 3 - Process Design Report, Phase I - Design and Permitting, Tangentially Fired Host Site, Illinois Power Company, Hennepin Station Unit 1", Prepared under U.S. DOE Cooperative Agreement, DE-FC22-87PC79796, Gas Research Institute Contract No. 5087254-149, State of Illinois Coal and Energy Development Agreement, March 1989.

"Volume 4 - Engineering Design Report and Phase 2 Construction Plan, Phase I - Design and Permitting, Tangentially Fired Host Site, Illinois Power Company, Hennepin Station Unit 1", Prepared under U.S. DOE Cooperative Agreement, DE-FC22-87PC79796, Gas 
Research Institute Contract No. 5087-254-149, State of Illinois Coal and Energy Development Agreement, March 1989.

"Volume 5 - Environmental Report, Phase I - Design and Permitting, Tangentially Fired Host Site, Illinois Power Company, Hennepin Station Unit 1", Prepared under U.S. DOE Cooperative Agreement, DE-FC22-87PC79796, Gas Research Institute Contract No. 5087254-149, State of Illinois Coal and Energy Development Agreement, March 1989.

"Volume 6 - Phase 3 Test Plan, Phase I - Design and Permitting, Tangentially Fired Host Site, Illinois Power Company, Hennepin Station Unit 1", Prepared under U.S. DOE Cooperative Agreement, DE-FC22-87PC79796, Gas Research Institute Contract No. 5087254-149, State of Illinois Coal and Energy Development Agreement, March 1989.

"Volume 1 - Summary, Phase I - Design and Permitting, Cyclone Fired Host Site, City of Springfield Department of Water, Light \& Power, Lakeside Station Unit 7", Prepared under U.S. DOE Cooperative Agreement, DE-FC22-87PC79796, Gas Research Institute Contract No. 5087-254-149, State of Illinois Coal and Energy Development Agreement, April 1989.

"Volume 2 - Baseline Test Report, Phase I - Design and Permitting, Cyclone Fired Host Site, City of Springfield Department of Water, Light \& Power, Lakeside Station Unit 7", Prepared under U.S. DOE Cooperative Agreement, DE-FC22-87PC79796, Gas Research Institute Contract No. 5087- 254-149, State of Illinois Coal and Energy Development Agreement, April 1989.

"Volume 3 - Process Design Report, Phase I - Design and Permitting, Cyclone Fired Host Site, City of Springfield Department of Water, Light \& Power, Lakeside Station Unit 7", Prepared under U.S. DOE Cooperative Agreement, DE-FC22-87PC79796, Gas Research Institute Contract No. 5087-254-149, State of Illinois Coal and Energy Development Agreement, April 1989.

"Volume 4 - Engineering Design Report and Phase II Construction Plan, Phase I - Design and Permitting, Cyclone Fired Host Site, City of Springfield Department of Water, Light \& Power, Lakeside Station Unit 7", Prepared under U.S. DOE Cooperative Agreement, DEFC22-87PC79796, Gas Research Institute Contract No. 5087-254-149, State of Illinois Coal and Energy Development Agreement, April 1989.

"Volume 5 - Environmental Report, Phase I - Design and Permitting, Cyclone Fired Host Site, City of Springfield Department of Water, Light \& Power, Lakeside Station Unit 7", Prepared under U.S. DOE Cooperative Agreement, DE-FC22-87PC79796, Gas Research Institute Contract No. 5087-254-149, State of Illinois Coal and Energy Development Agreement, April 1989. 
"Volume 6 - Phase 3 Test Plan, Phase I - Design and Permitting, Cyclone Fired Host Site, City of Springfield Department of Water, Light \& Power, Lakeside Station Unit 7", Prepared under U.S. DOE Cooperative Agreement, DE-FC22-87PC79796, Gas Research institute Contract No. 5087-254-149, State of Illinois Coal and Energy Development Agreement, April 1989.

"Volume 1 - Summary, Phase I - Design and Permitting, Wall Fired Host Site, Central Illinois Light Company, Edwards Station Unit 1", Prepared under U.S. DOE Cooperative Agreement, DE-FC22-87PC79796, Gas Research Institute Contract No. 5087-254-149, State of Illinois Coal and Energy Development Agreement, April 1989.

"Volume 2 - Baseline Test Report, Phase I - Design and Permitting, Wall Fired Host Site, Central Illinois Light Company, Edwards Station Unit 1", Prepared under U.S. DOE Cooperative Agreement, DE-FC22-87PC79796, Gas Research Institute Contract No. 5087254-149, State of Illinois Coal and Energy Development Agreement, April 1989.

"Volume 3 - Process Design Report, Phase I - Design and Permitting, Wall Fired Host Site, Central Illinois Light Company, Edwards Station Unit 1", Prepared under U.S. DOE Cooperative Agreement, DE-FC22-87PC79796, Gas Research Institute Contract No. 5087254-149, State of Illinois Coal and Energy Development Agreement, April 1989.

"Volume 4 - Engineering Design Report and Phase II Construction Plan, Phase I - Design and Permitting, Wall Fired Host Site, Central Illinois Light Company, Edwards Station Unit 1", Prepared under U.S. DOE Cooperative Agreement, DE-FC22-87PC79796, Gas Research Institute Contract No. 5087-254-149, State of Illinois Coal and Energy Development Agreement, April 1989.

"Volume 5 - Environmental Report, Phase I - Design and Permitting, Wall Fired Host Site, Central Illinois Light Company, Edwards Station Unit 1", Prepared under U.S. DOE Cooperative Agreement, DE-FC22-87PC79796, Gas Research Institute Contract No. 5087254-149, State of Illinois Coal and Energy Development Agreement, April 1989.

"Volume 6 - Phase 3 Test Plan, Phase I - Design and Permitting, Wall Fired Host Site, Central Illinois Light Company, Edwards Station Unit 1", Prepared under U.S. DOE Cooperative Agreement, DE-FC22-87PC79796, Gas Research Institute Contract No. 5087254-149, State of Illinois Coal and Energy Development Agreement, April 1989.

"Volume 1 - Gas Reburning-Sorbent Injection Program Overview", Prepared under U.S. DOE Cooperative Agreement, DE-FC22-87PC79796, Gas Research Institute Contract No. 5087-254-149; Illinois Department of Commerce and Community Affairs Agreement, April 1996. 
"Volume 2 - Gas Reburning-Sorbent Injection at Hennepin Unit 1, Illinois Power Company", Prepared under U.S. DOE Cooperative Agreement, DE-FC22-87PC79796, Gas Research Institute Contract No. 5087-254-149, Illinois Department of Commerce and Community Affairs Agreement, March 1996.

"Volume 3 - Gas Reburning-Sorbent Injection at Edwards Unit, Central Illinois Light Company", Prepared under U.S. DOE Cooperative Agreement, DE-FC22-87PC79796, Gas Research Institute Contract No. 5087-254-149, Illinois Department of Commerce and Community Affairs Agreement, March 1996.

"Volume 4 - Gas Reburning-Sorbent Injection at Lakeside Unit 7, City Water Light \& Power, Springfield, Illinois", Prepared under U.S. DOE Cooperative Agreement, DE-FC2287PC79796, Gas Research Institute Contract No. 5087-254-149, Illinois Department of Commerce and Community Affairs Agreement, March 1996. 